ص ص [301-273]

$$
\begin{aligned}
& \text { العلاقة بين أنشطة إدارة المواد وأبعاد أداء العمليات }
\end{aligned}
$$

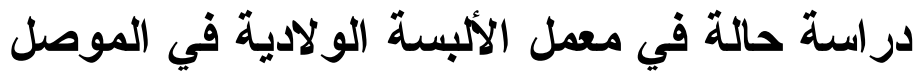

$$
\begin{aligned}
& \text { غائم ممود أهمد الكيكي } \\
& \text { مدرس مساعد-قسم الإدارة الصناعية } \\
& \text { كلية الإدارة والاقتصاد -جامعة الموصل }
\end{aligned}
$$

\author{
الدكتور آكم اهد الطويل

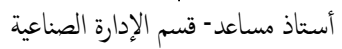 \\ كلية الإدارة والاقتصاد- جامعة الموصل
}

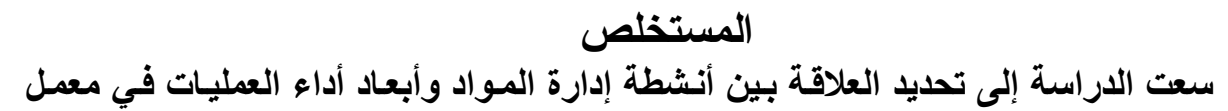

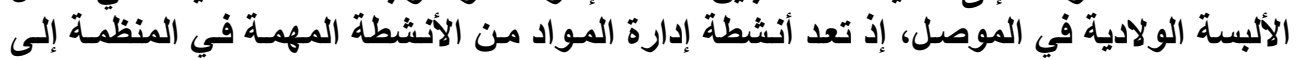

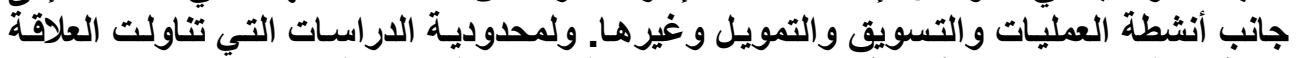

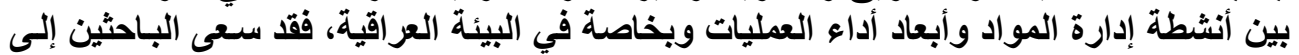

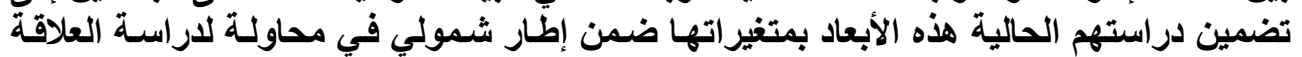

وبشكل عام تحاول هذه الدراسة الإجابة عن التساؤلات الآتية:

$$
\text { بينهما. }
$$

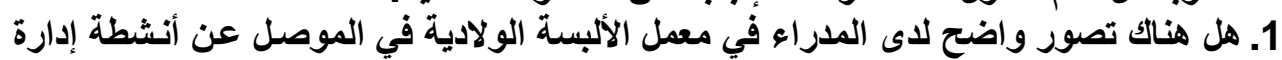

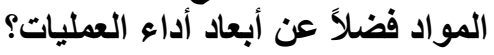

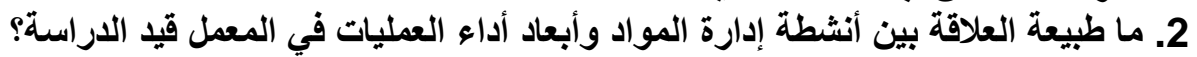

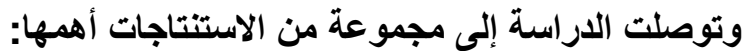

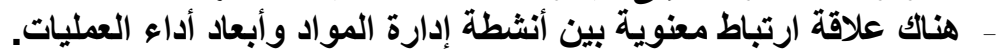

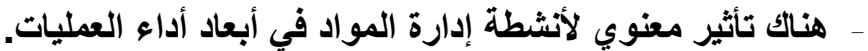

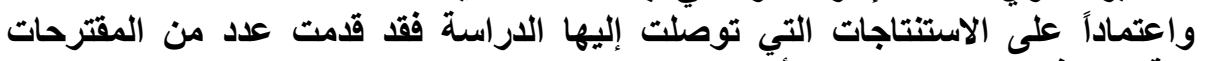

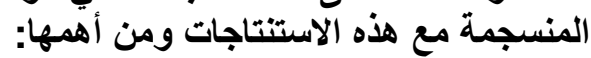

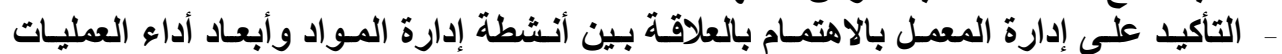

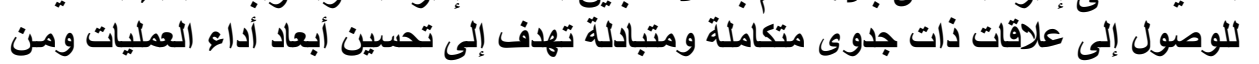

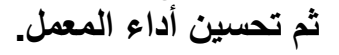




\title{
Relationship between the Activities of Materials Management and the Dimensions of Operations performance A Case Study in the Factory of Ready-Made Clothes at Mosul City
}

\author{
Akram Ahmed Al-Taweel (PhD) \\ Assistant Professor \\ Department of Industrial Management \\ akramtaweel@yahoo.co.uk
}

\author{
Ghanim Mahmoud Ahmed Al-Keeky \\ Assistant Lecturer \\ Department of Industrial Management \\ ghanimahmed 62@yahoo.co.uk
}

\begin{abstract}
The study sought for determining the relationship between the activities of materials management and the dimensions of processes performance in the Factory of Ready-Made Clothes in Mosul, where these activities of materials management are considered of the important activities in the organization beside the activities of operations, marketing, financing and others. Because of the limitedness of studies which tackled the relationship between the activities of materials management and the dimensions of processes performance and especially in the Iraqi environment. The two researchers, in their present study, sought for including these dimensions in their variables within a thorough frame in an attempt to study the relationship between them.

Generally, the study tries to answer the following inquiries:

1. Is there a clear imagination for the managers in the Factory of Ready-Made Clothes in Mosul about the activities of materials management and the dimensions of processes performance?

2. What is the nature of the relationship between the activities of materials management and the dimensions of processes performance in the factory under study?

The study reached to a set of some important conclusions:

- There is a significant connection relationship between the activities of materials management and the dimensions of processes performance.

- There is a significant effect for the activities of materials management in the dimensions of processes performance.

Depending on the conclusions, which the study achieved, a set of harmonized suggestions with these conclusions have been presented, one of the most important suggestions:

- The management of factory must emphasize on the relationship between the activities of materials management and the dimensions of processes performance to reach the integrated and interchange relationships that aims to improve the dimensions of processes performance then improving the factory performance.
\end{abstract}

المقدمة

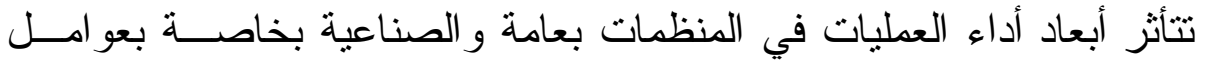

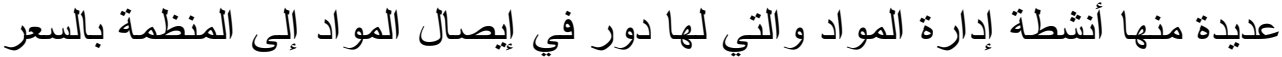

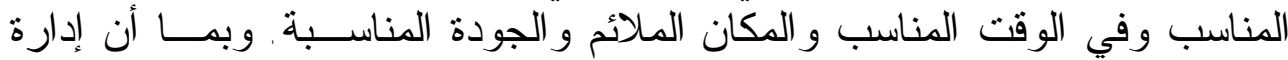

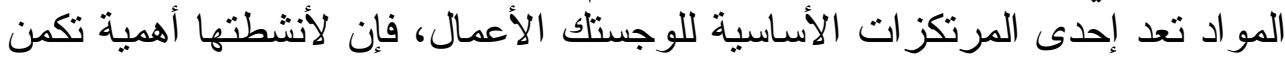

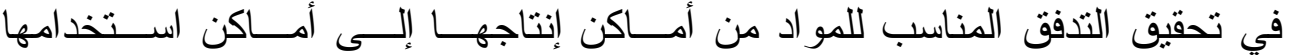




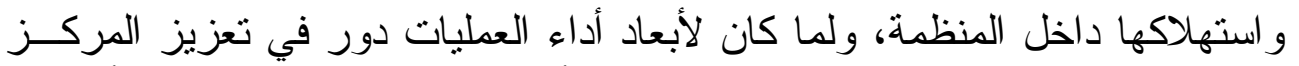

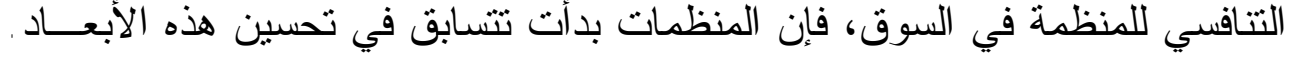

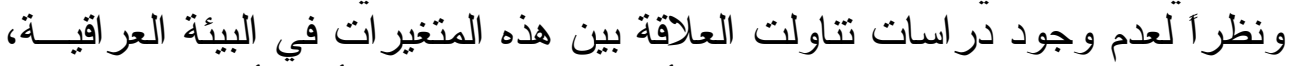

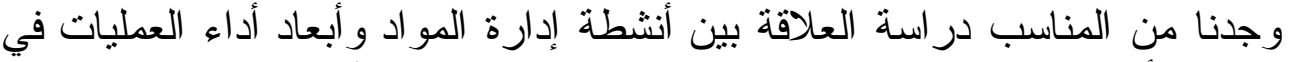

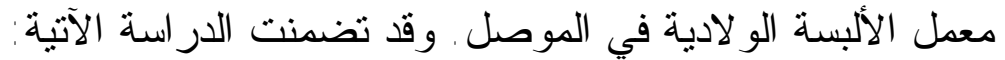

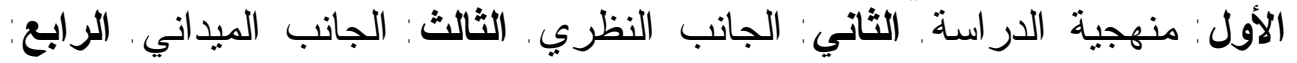

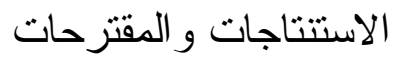

$$
\begin{aligned}
& \text { منهجية الدر اسة } \\
& \text { بتضمن هذا الدحور مايأتي: } \\
& \text { أولاً - مشكلة الدار اسة المة }
\end{aligned}
$$

تولي الثركات الصناعية وخاصة في الدول المتقدمة إهنمامأ متز ايداً بأنشطة

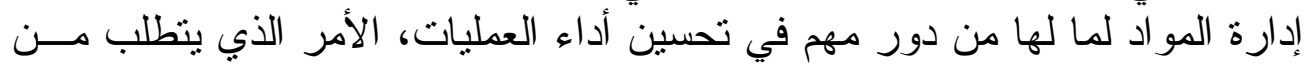

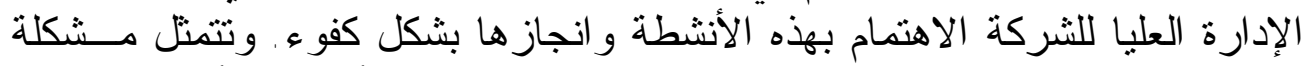

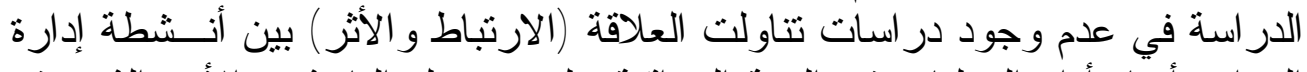

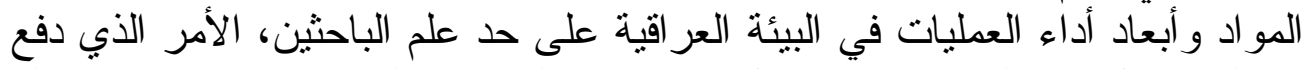

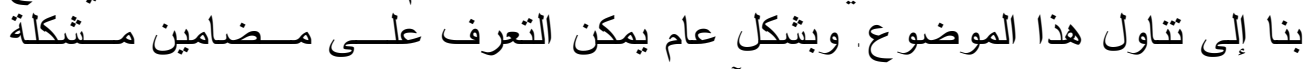

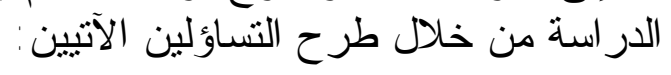

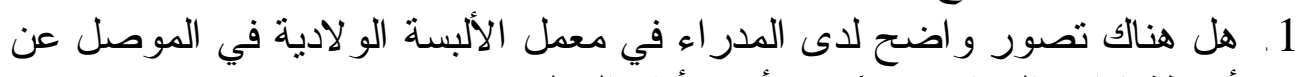

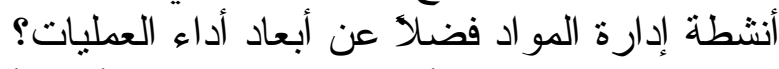

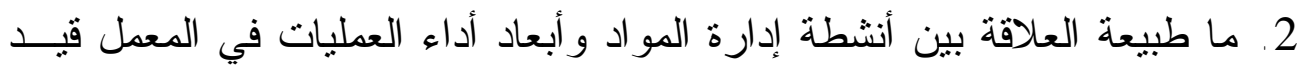
الدر اسة؟

$$
\text { ثانياً - أهداف الدراسة الدة الآتي: }
$$

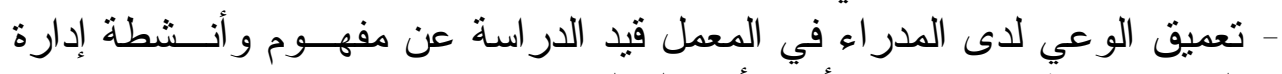

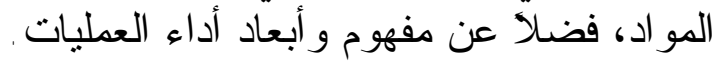
- اختبار العلاقة (الارنباط و الأثر) بين أنشطة إداءة إدارة المواد و أبعاد أداء العمليـات

$$
\text { ثي الثاً ـ أنموذج الدمل قيد الدراسة. }
$$

تم تصميم أنموذج فرضي كما في الثنكل 1 الذي يشير إلى العلاقة بين أنشطة إدارة المو اد و أبعاد أداء العمليات. 


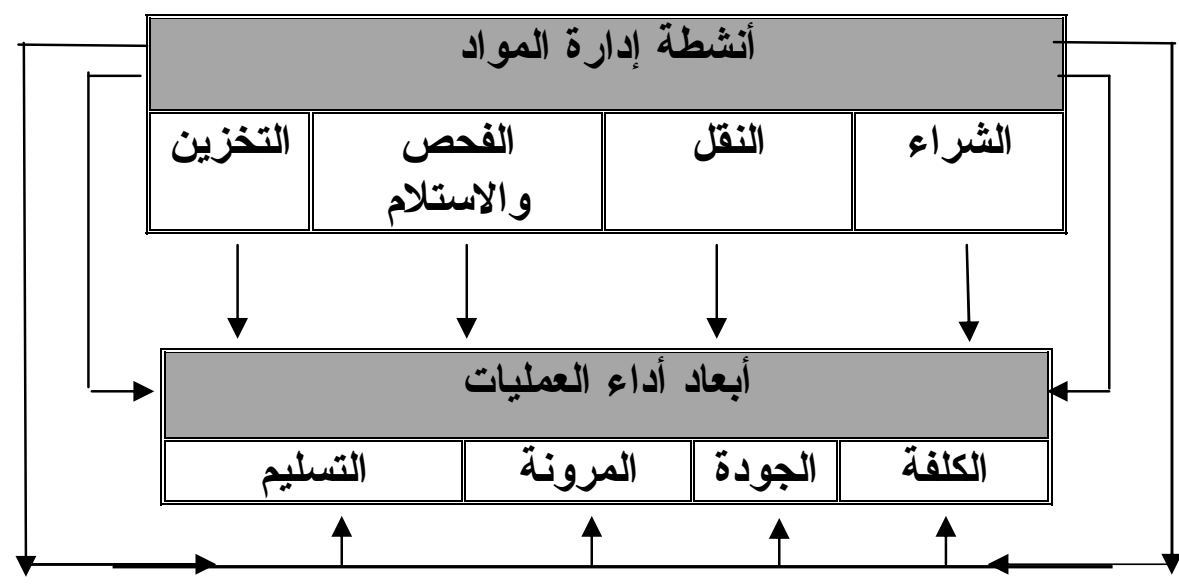

\section{1 الثنكل 1}

أنموذج الدراسة المن

رابعاً - فرضيات الاراسة

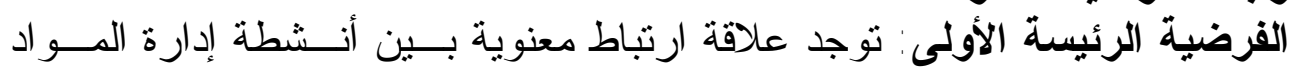

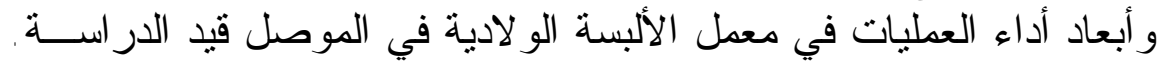

وتتبثق عنها الفرضيات الفرية الفية الآتية:

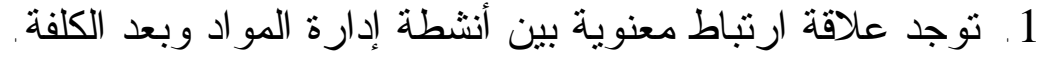

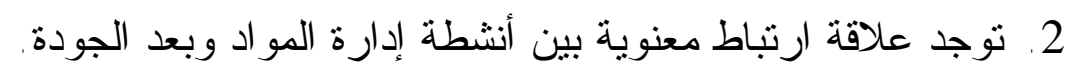

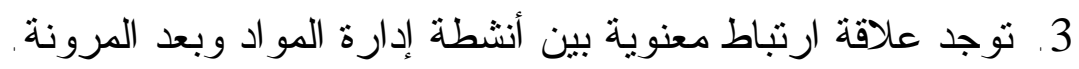

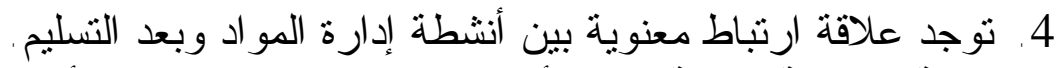

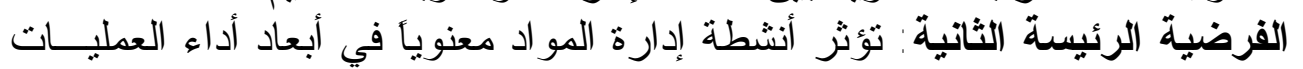

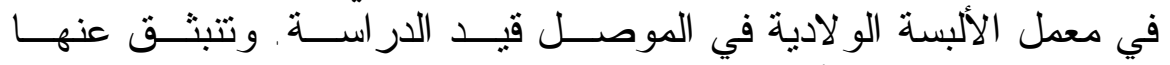

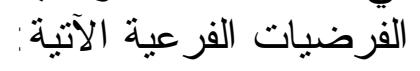

$$
\begin{aligned}
& \text { 1. نؤثر أنثطة إدارة المو اد معنوياً في بعد الكلفة. }
\end{aligned}
$$

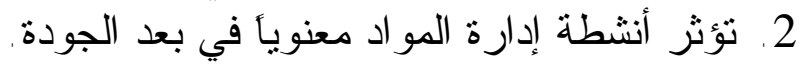

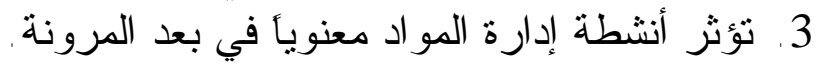

$$
\begin{aligned}
& \text { 4. تؤثر أنشطة إدارة المو اد معنوياً في بعد التسليم. }
\end{aligned}
$$

خامساً - منهج الاراسة

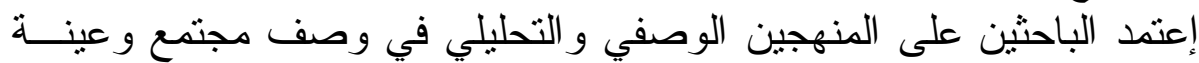

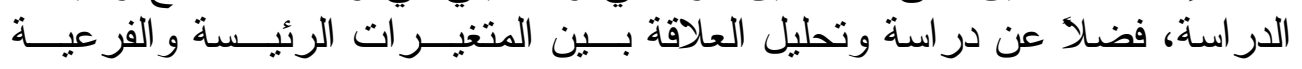

$$
\text { المعتمدة في الدر اسة . }
$$




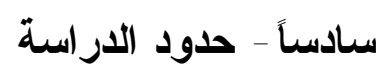

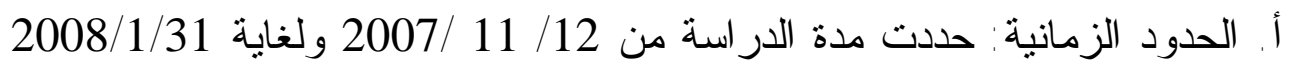

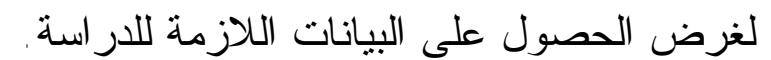

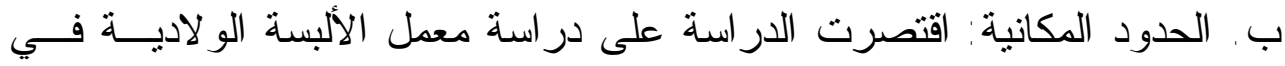

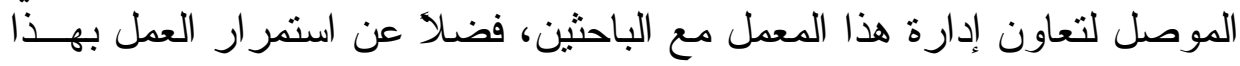

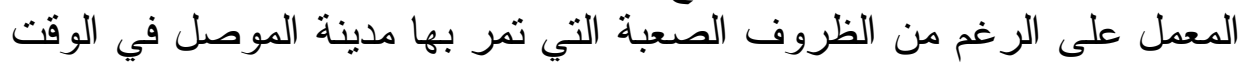

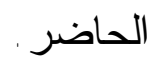

\section{سابعاً - أساليب جمع البيانات}

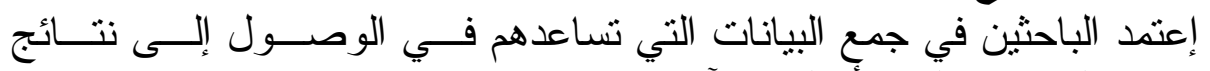

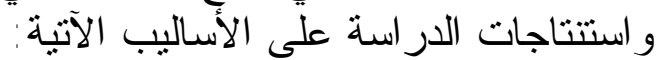

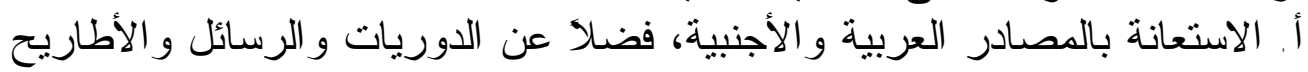

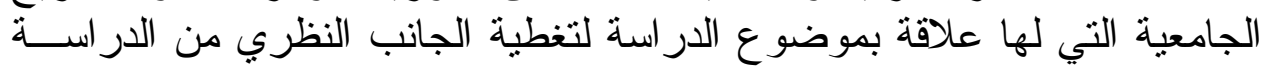
ودعم الجانب الميداني بها.

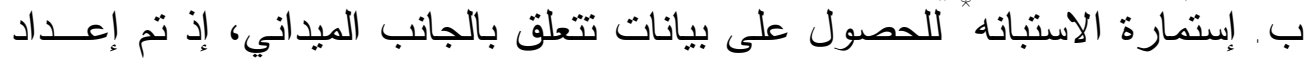

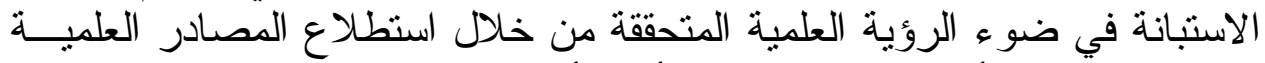

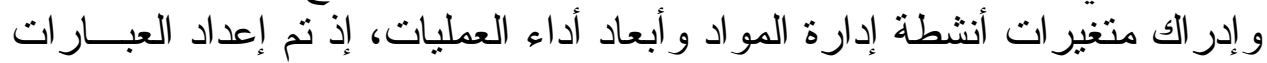

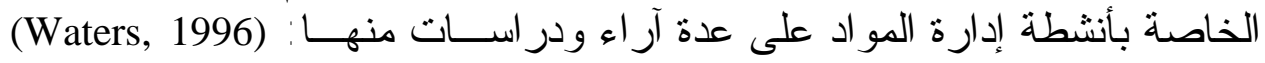
(Slack, (عقيلي و آخرون، (Evans, 1997) (Chase \& Aquilano, 1995)

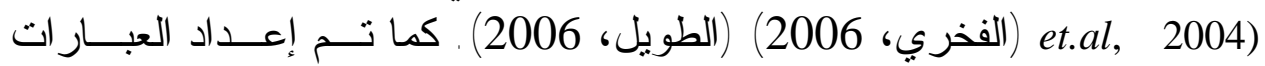
الخاصة بأبعاد أداء العمليات على عدة در اسات و آر اء منها:

(Slack, et. al, 2004) (Russell \& Taylor, 2000) (Markland, et. al, 1995) ( Krajewski \& Ritzman, 2005 ) ( الداؤودي، 2005) (كثموله، 2007).

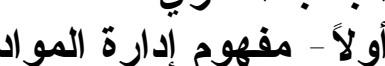

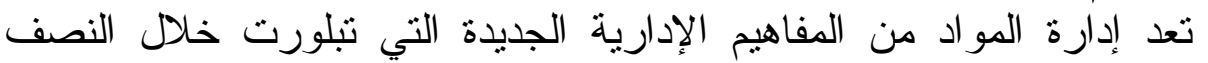

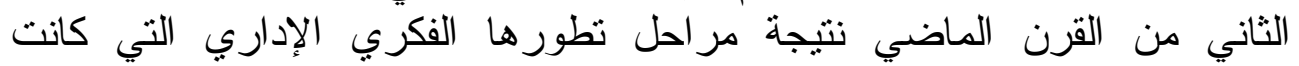

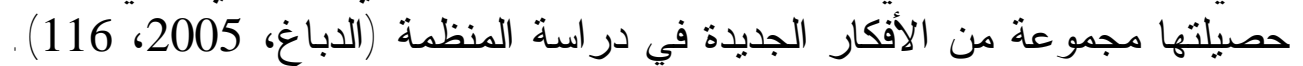

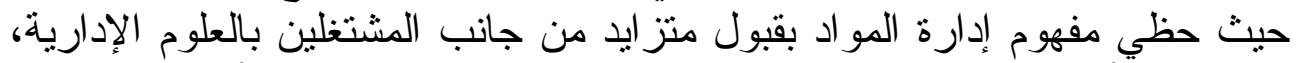

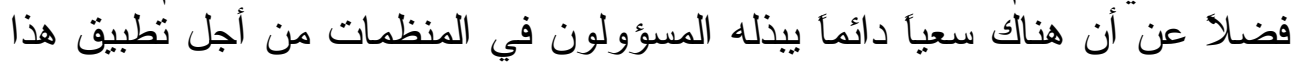

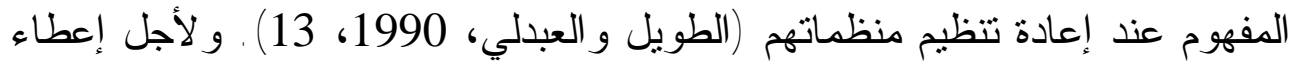
مفهوم دقيق لإدارة المو اد نستعرض التعاريف الآتية: 
الدكتور الطويل والكيكي [278

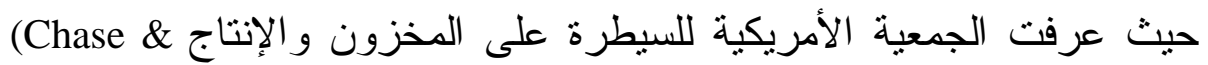

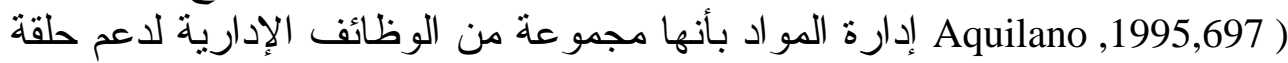

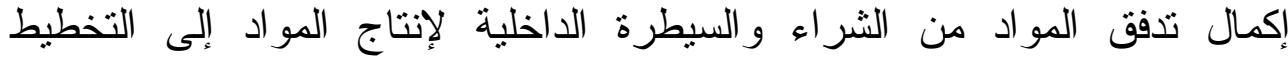

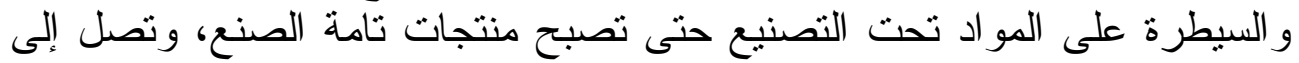
مخازن الإنتاج التام في المنظمة، ومن ثم شحنها وتوزيعها كمنتجات نهائية إلى

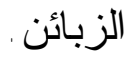
ويعرفها (Evans, 1997, 517) بأنها الإدارة التي تقوم بــالتخطيط و التتـسيق

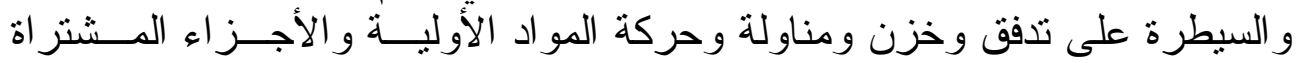

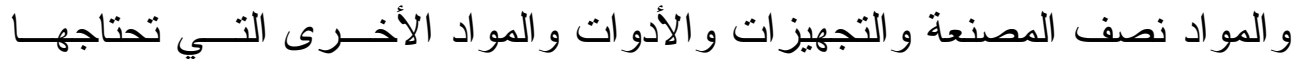

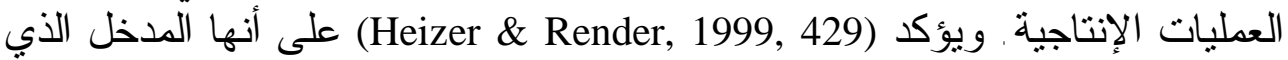

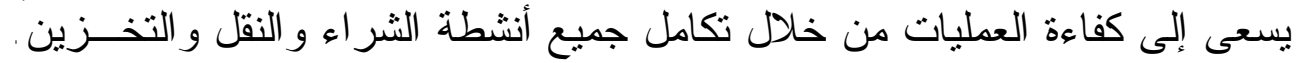

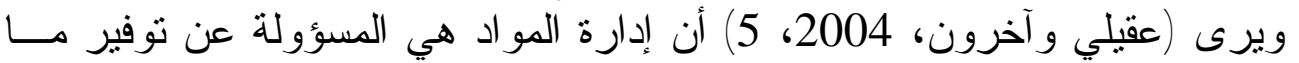

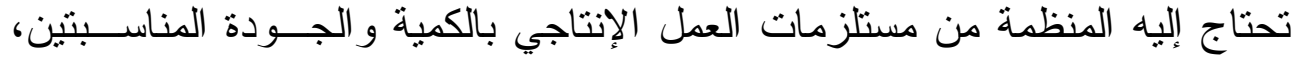

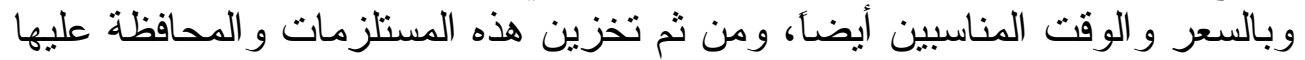

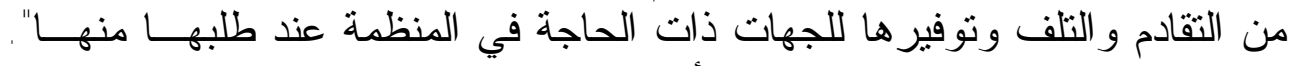

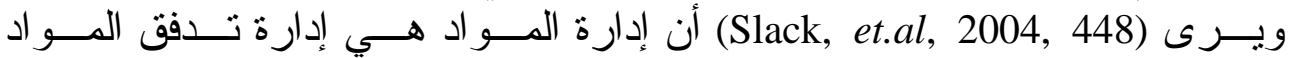

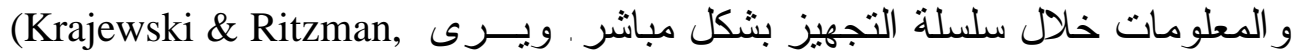

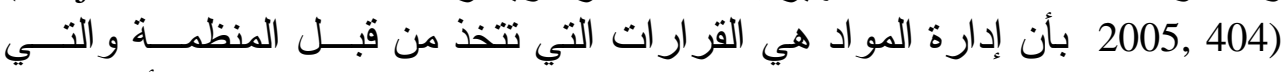

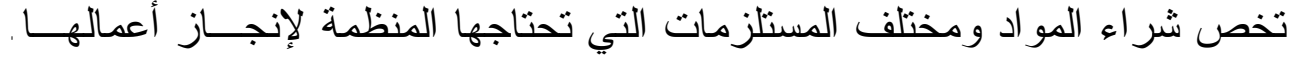

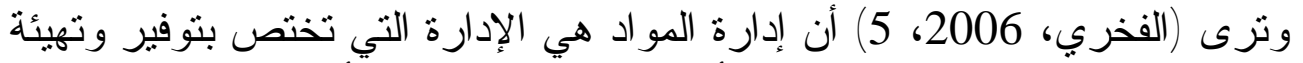

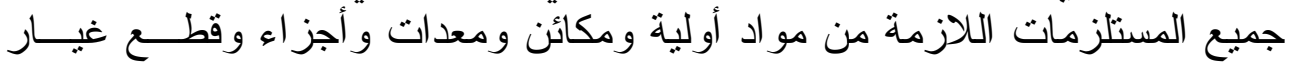

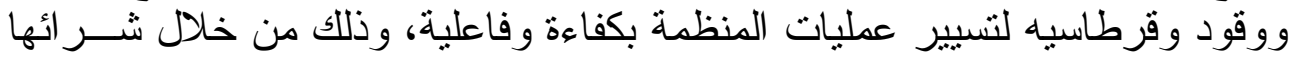

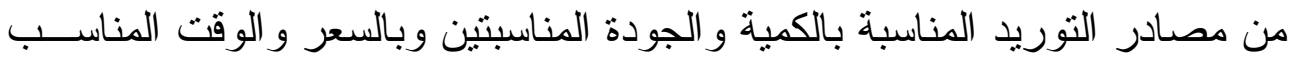

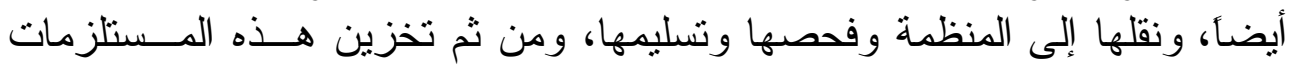

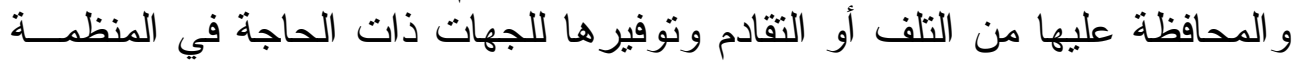

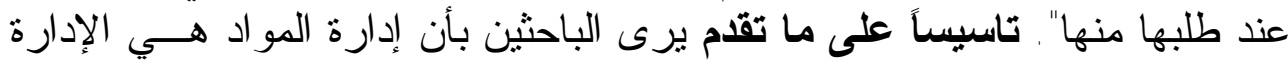

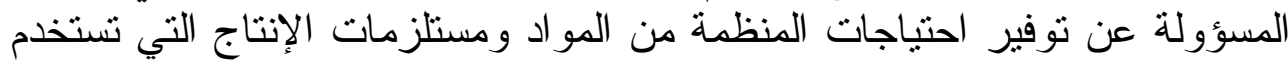

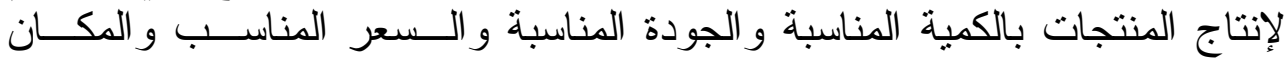

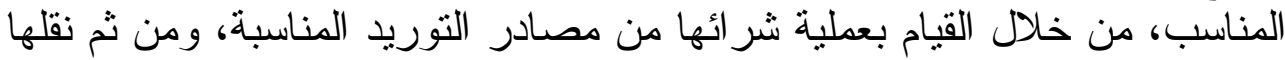

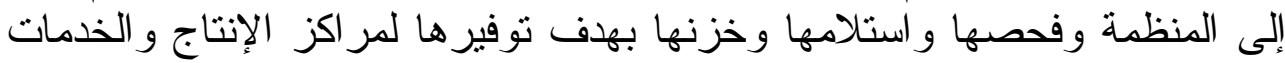

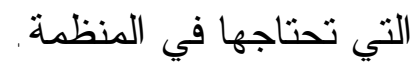

ثانياً - أنثطة إدارة المواد المعتمدة في الاراسة

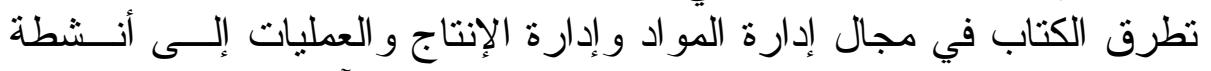

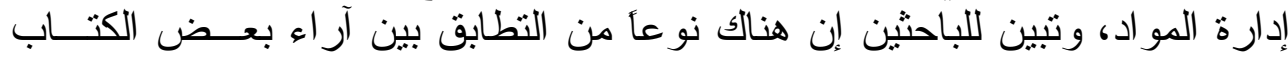

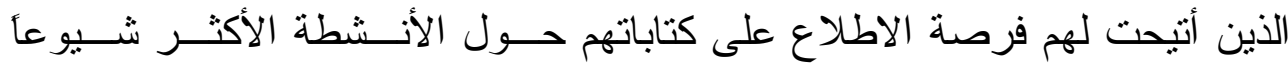




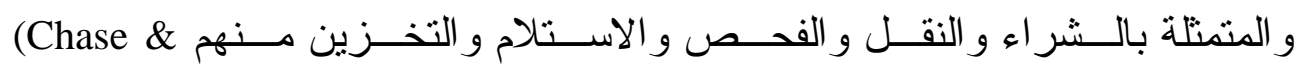
(عlack, et.al, 2004, 448) (Evans, 1997, 518) Aquilano,1995,698)

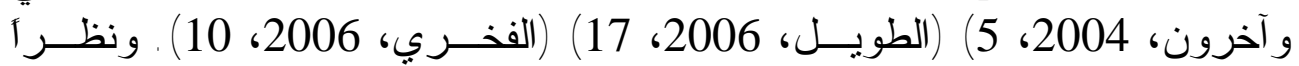

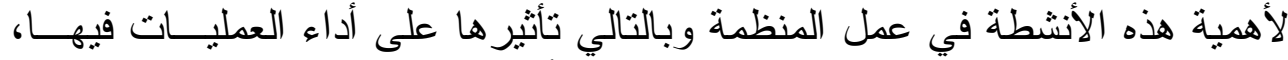

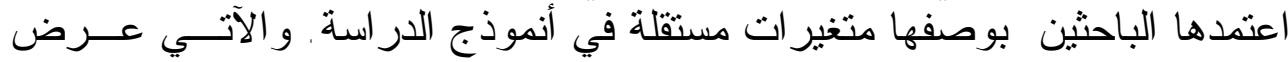
موجز لكل منها: أ. نشاط الشر اء: يعد نشاط الثر اء من الأنشطة التي لا يمكن لأي منظمـــة مــن

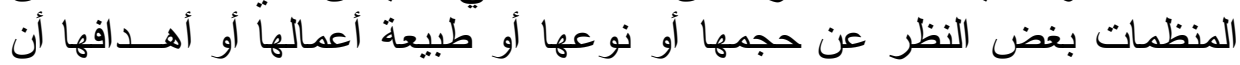

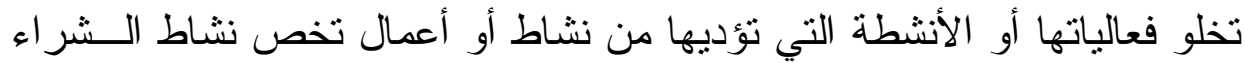

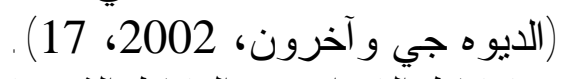

فنشاط الثر اء هو النشاط الذي يقوم بتوريد المواد و الخدمات من المــوردين

(Chase \& Aquilano, 1995, 696) بأن نشاط الثر اء يعد من أكثر الأنشطة أهمية في إدارة المواد، وهو المو عملية اقتتــاء

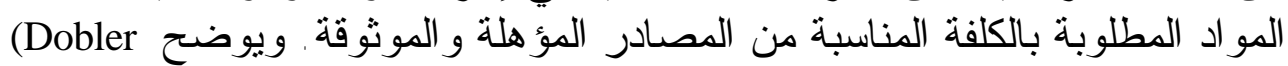
\& Burt, 1996, 35)

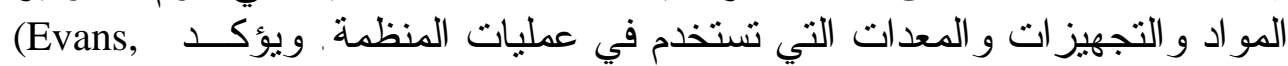

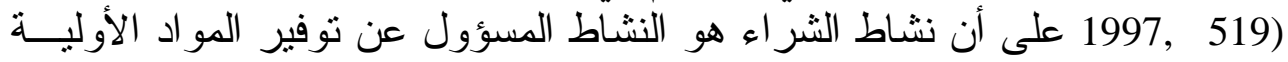

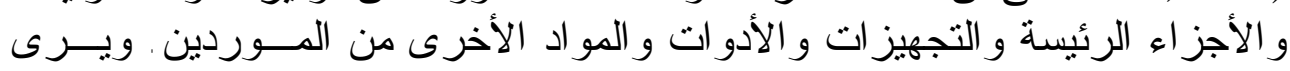

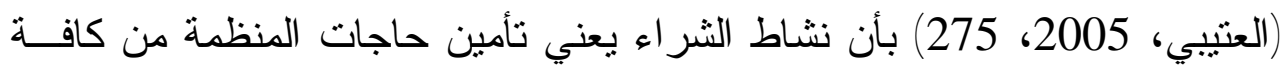

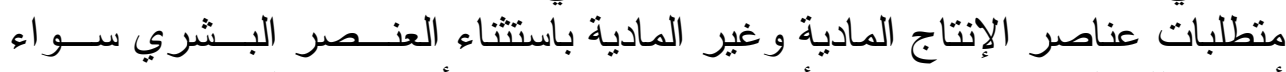

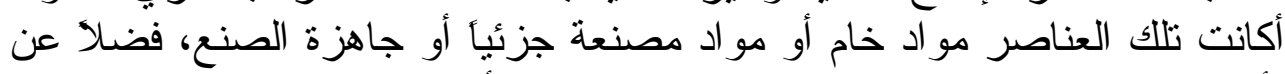

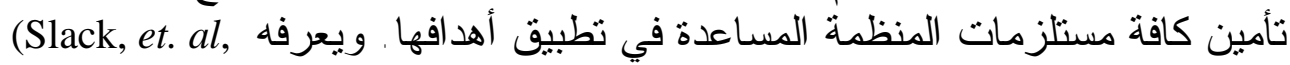

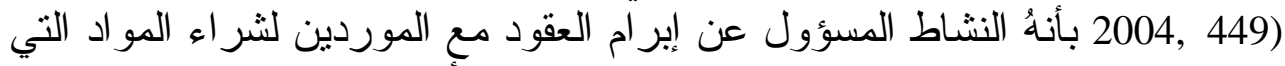

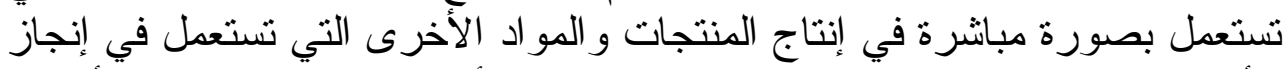

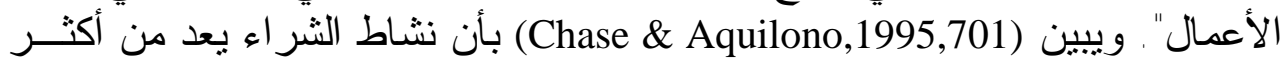

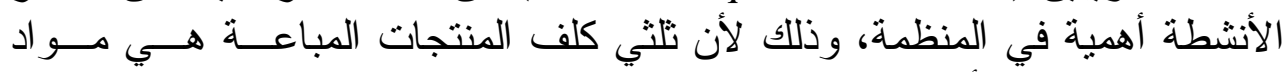

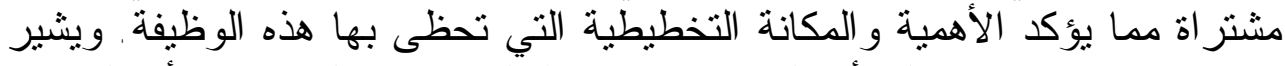
(Waters,1996, 594)

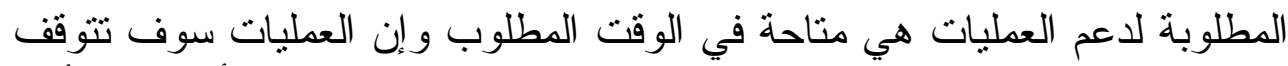

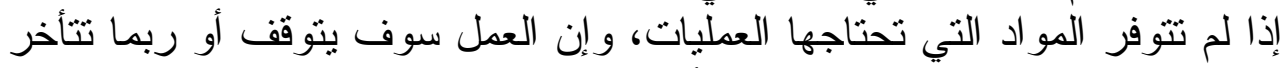

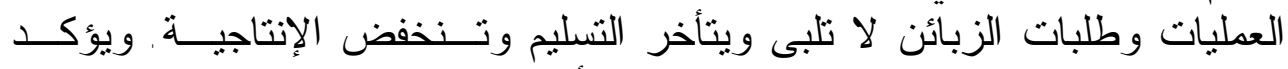
(Krajewski \& Ritzman, 2005, 404)

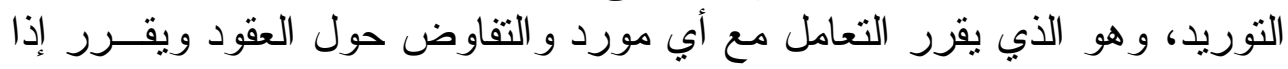

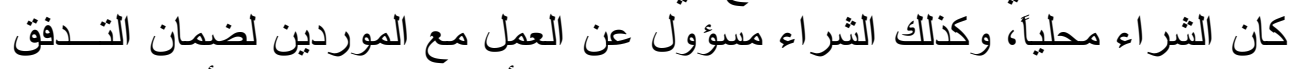

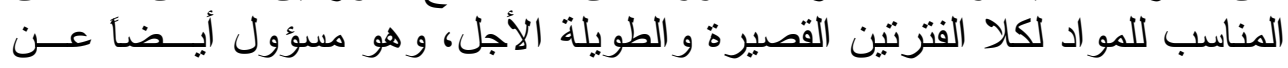


الدكتور الطويل والكيكي [280]

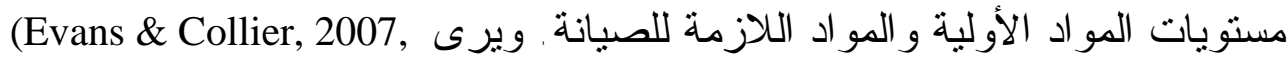

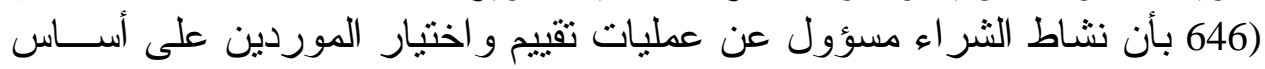

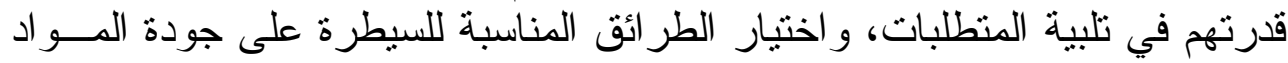

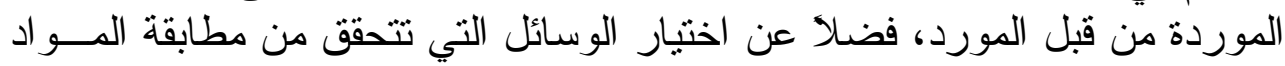

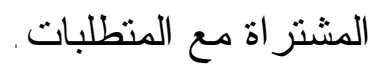

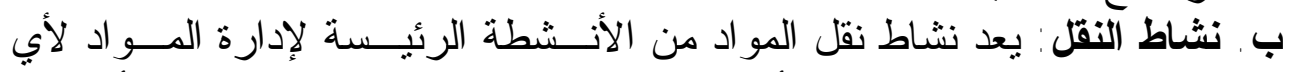

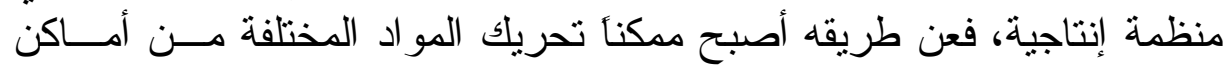

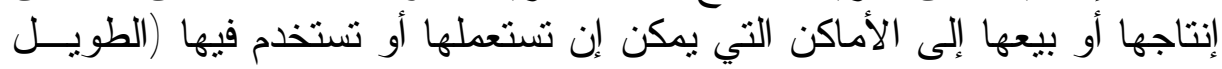

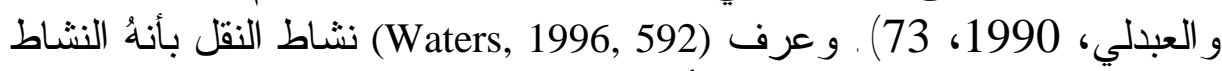

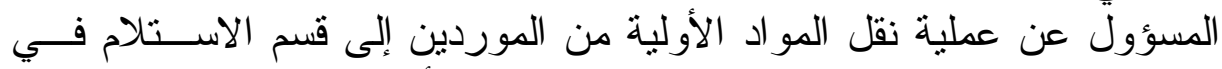

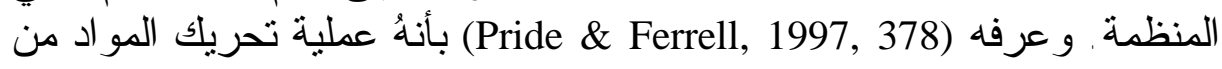

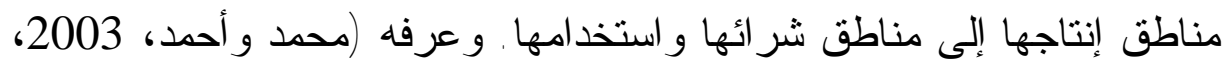

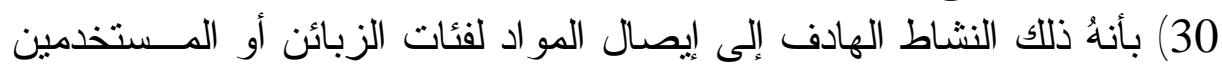

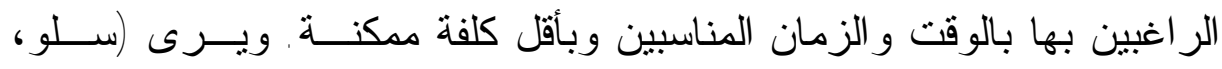

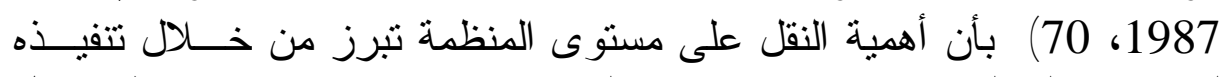

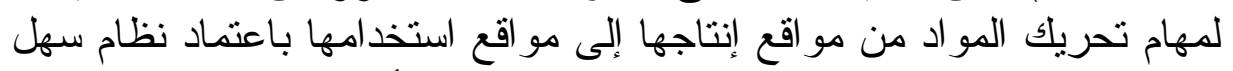

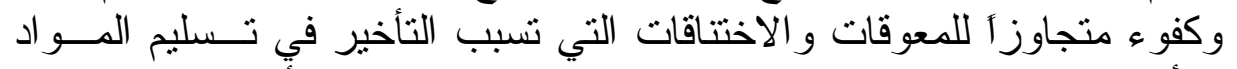

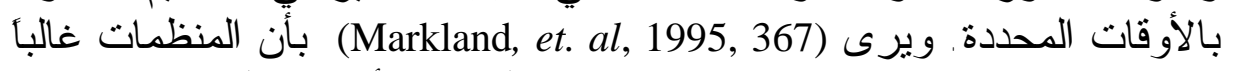

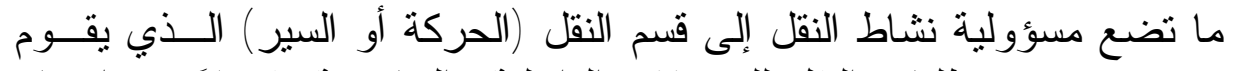

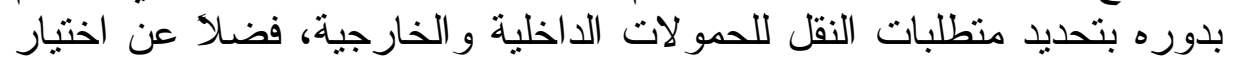

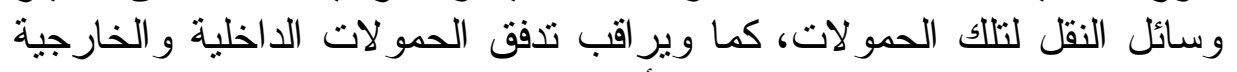

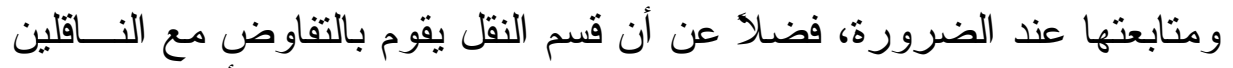

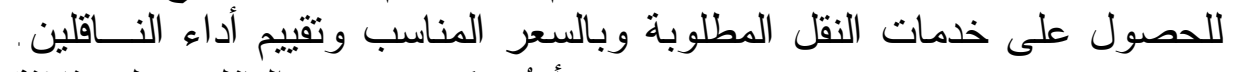

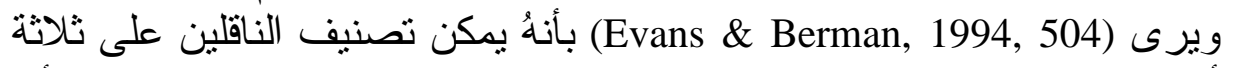

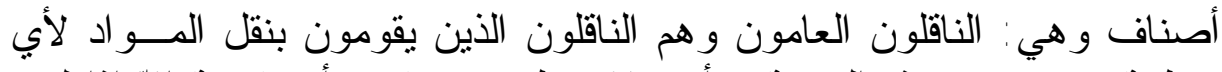

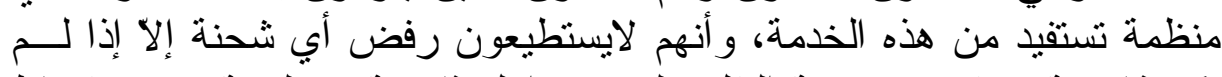

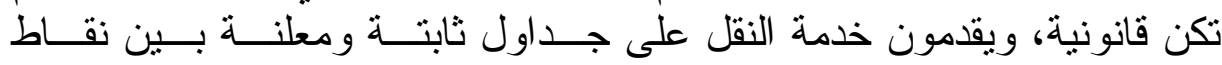

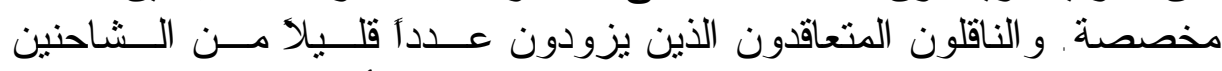

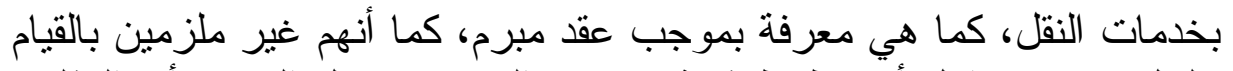

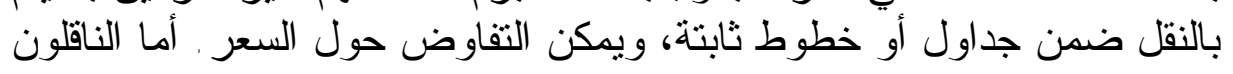

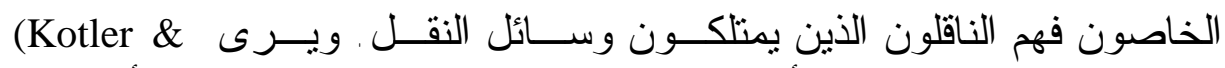
Armstrong, 1999, 375)

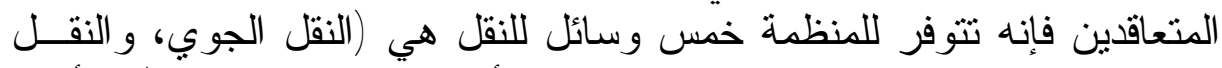

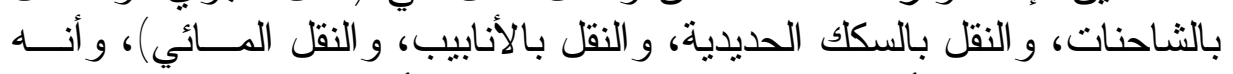

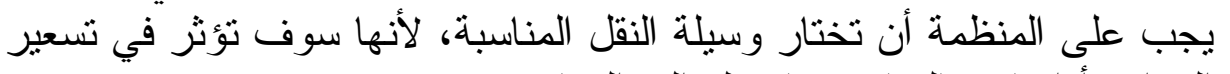

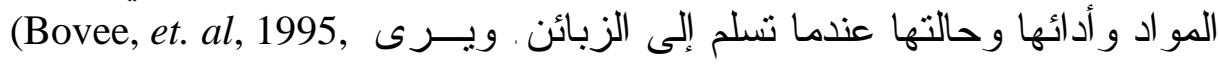


(498 بأن هناك مجموعة من المعايير يمكن للمنظمة إن تسترشد بها للمفاضلة

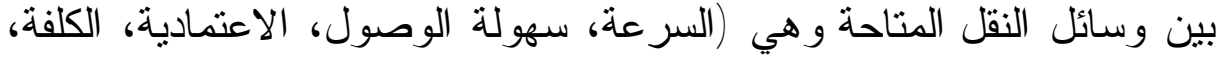

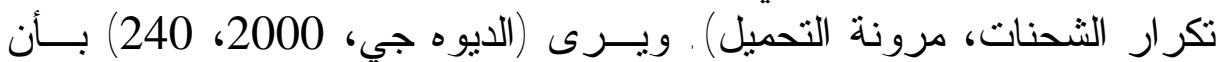

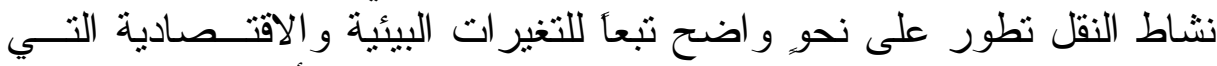

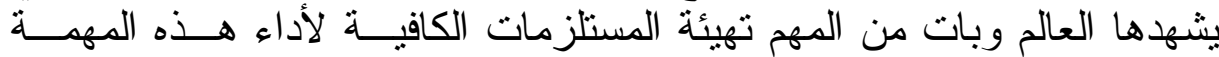

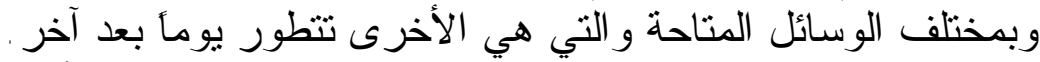

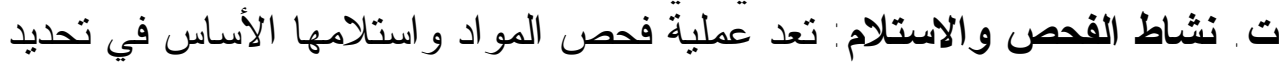

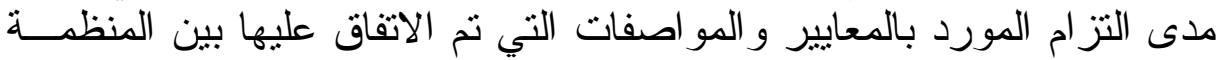

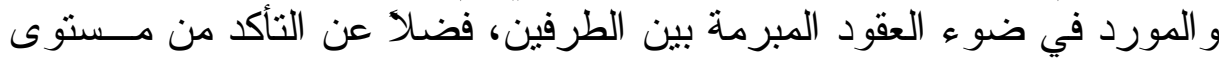

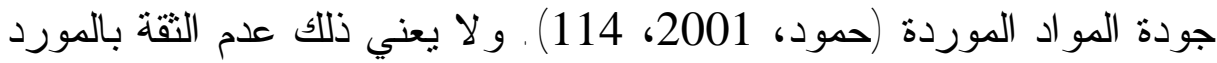

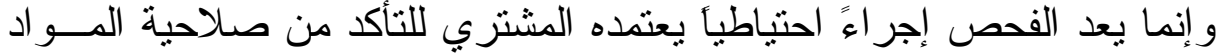

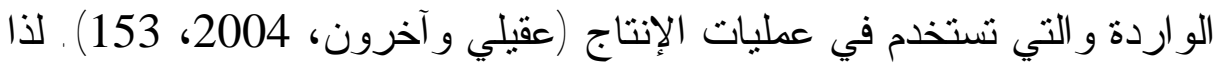

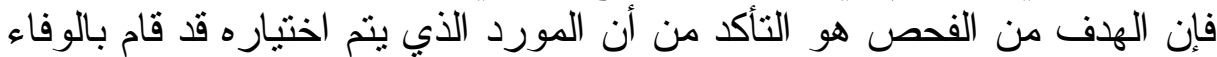

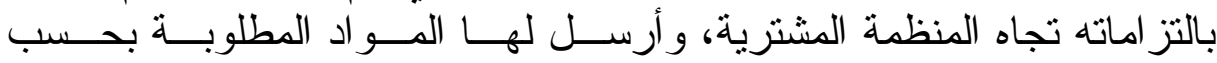
المو اصفات التي تم تحديدها سابقاً و الوارد ذكر ها في أمر الــشر اء (المــؤذن،

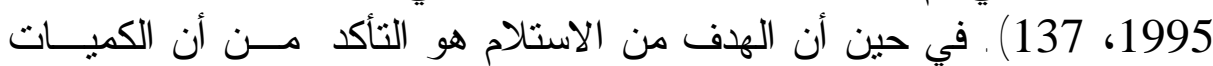

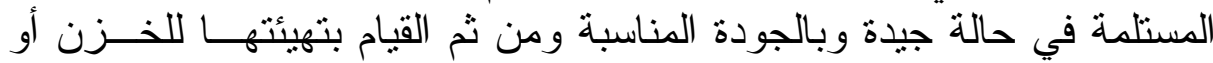

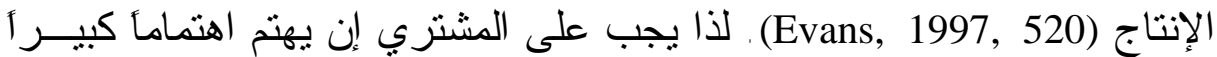

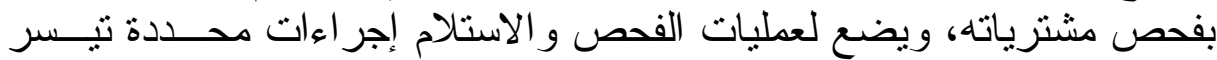

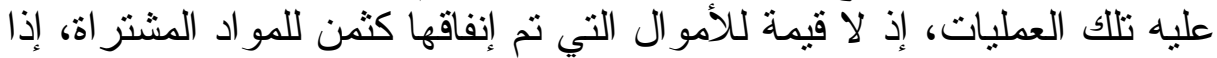

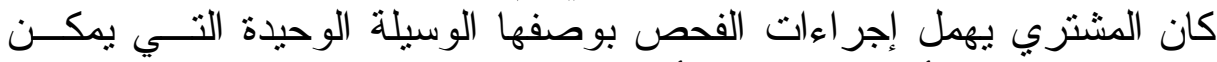

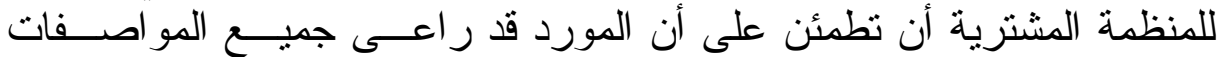

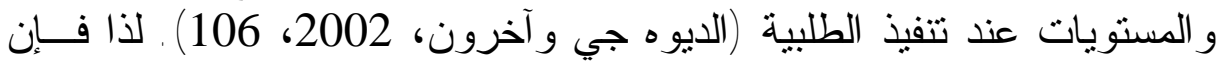

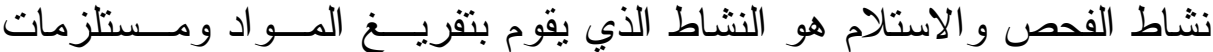

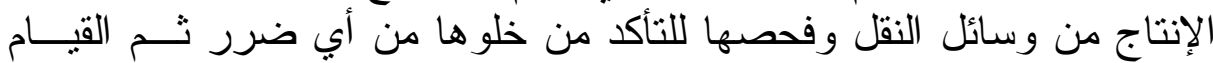

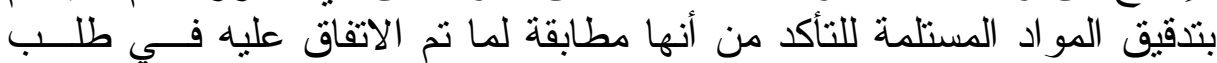

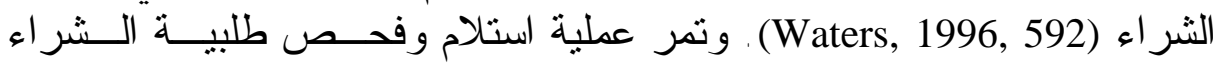

$$
\text { بمرحلتين هما (عقيلي و آخرون، 2004، 154 (1592): }
$$

- الاستلام والفحص الظاهري: ويتت فيه فحص طلبية الثر اء ظاهريآ، وذللك للتأكد

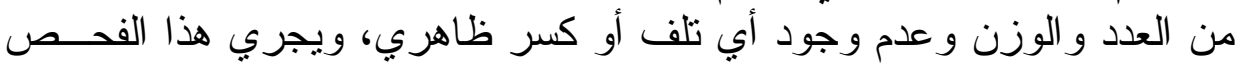

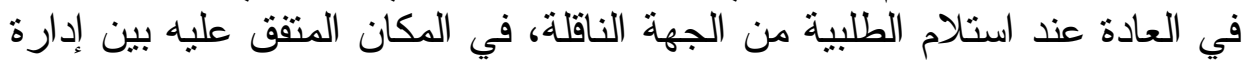

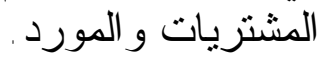
- الفحص الدقيق: ويتم فيه فحص طلبية الثر اء بصورة دقيقة، وذلك للتأكد مــن

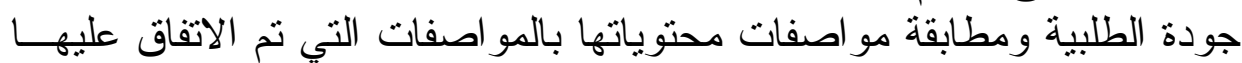
مع المورد بحسب ما جاء في أمر التوريد. 
الدكتور الطويل والكيكي [282]

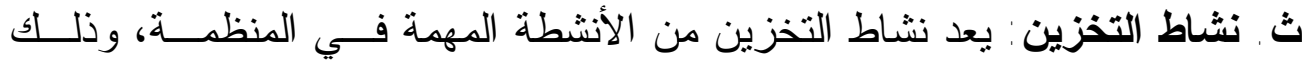

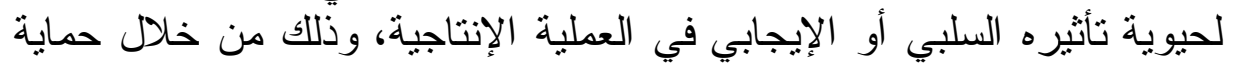

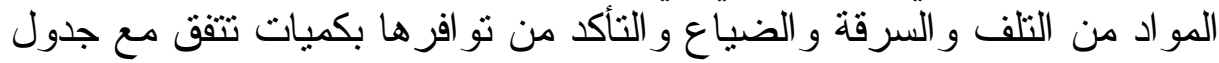
الإنتاج، بحيث لا يترتب على سوء إدارة هذه العملية نقاط اختتاق في الإنعليات

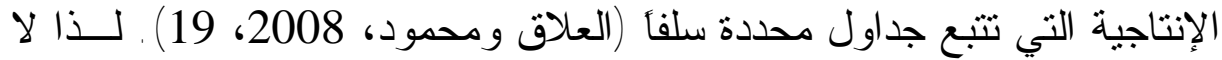

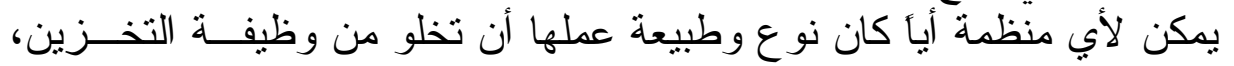

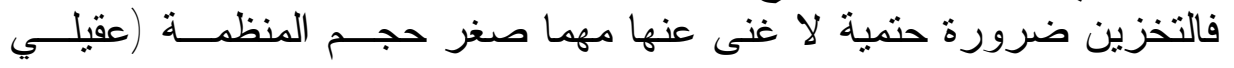

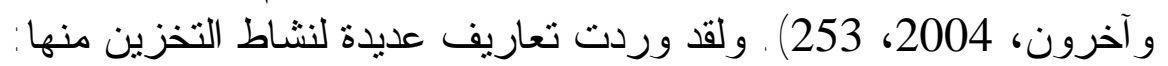
- عملية خزن المواد و المحافظة عليها لحين الحاجة إليها (Waters, 1996, 592).

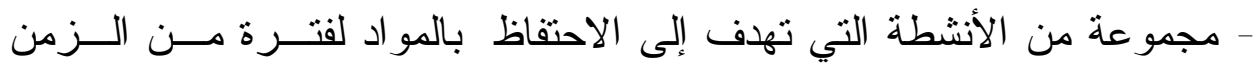

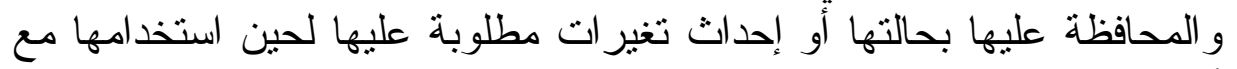

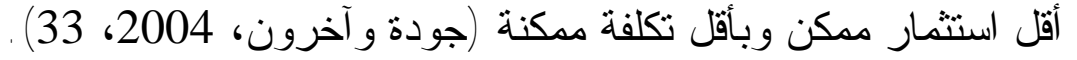

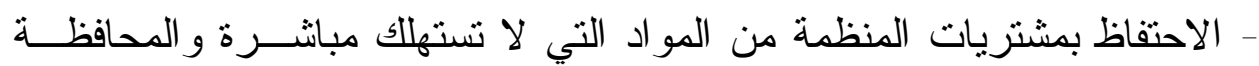

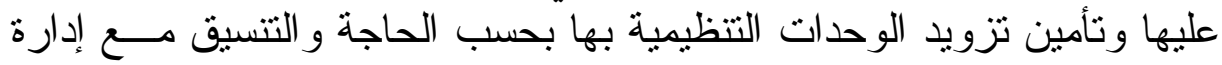

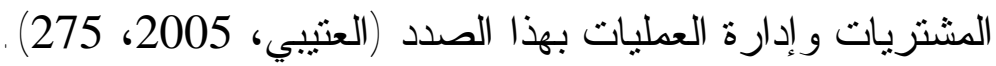

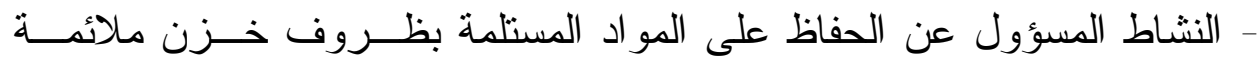

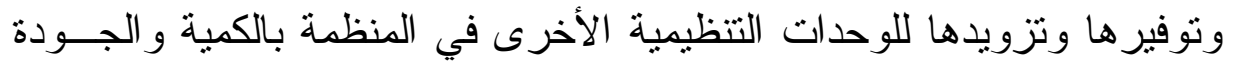

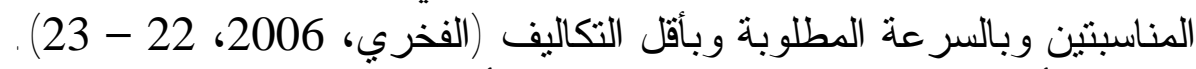

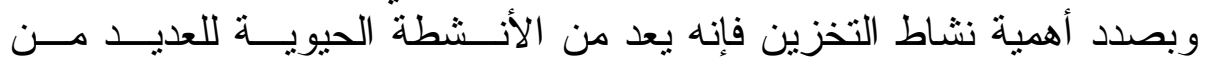

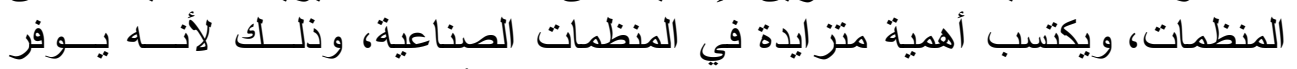

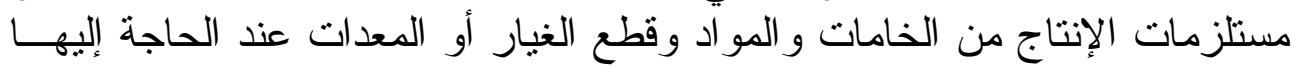

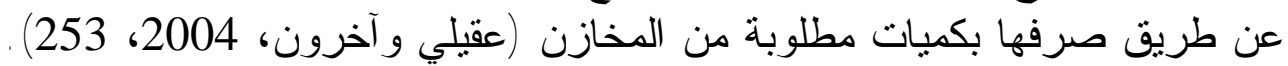

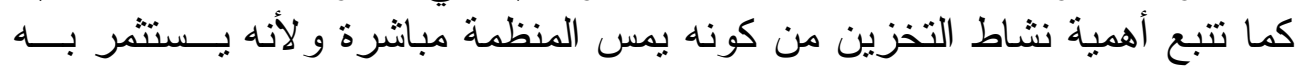

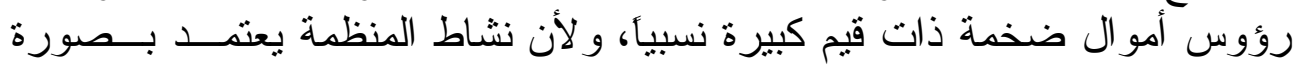

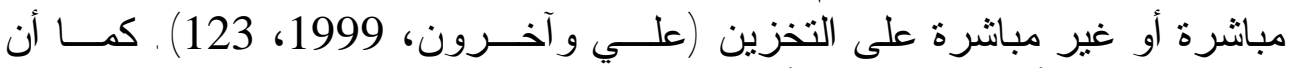

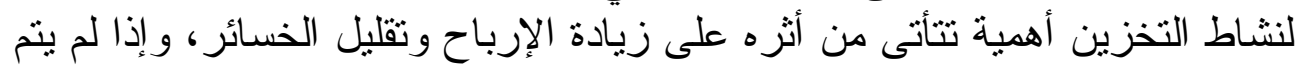

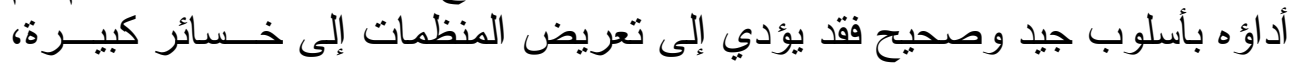

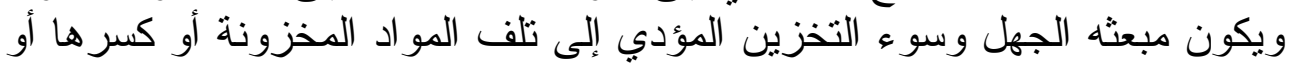

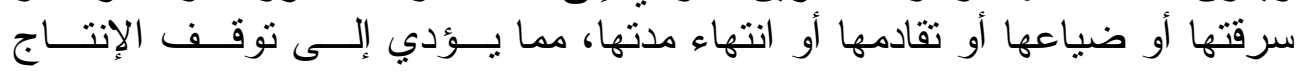

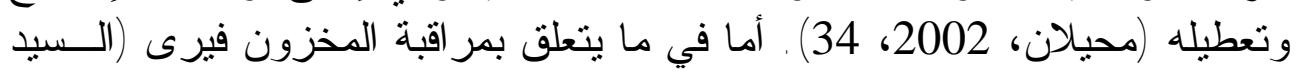

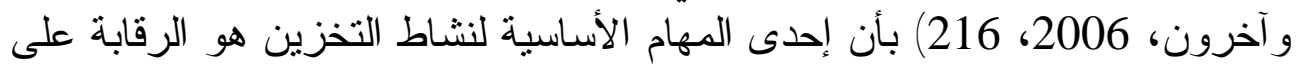

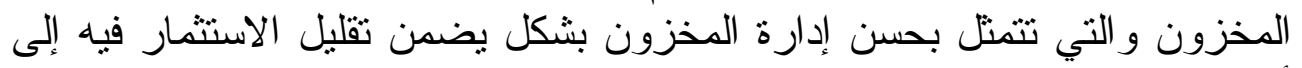

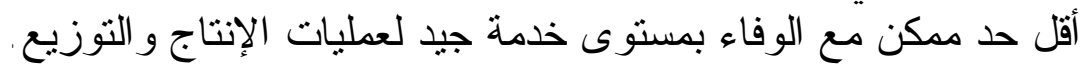




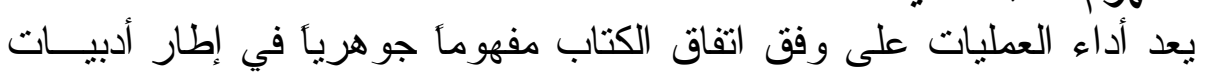
ثالثاً - مفهوم أداء العمليات

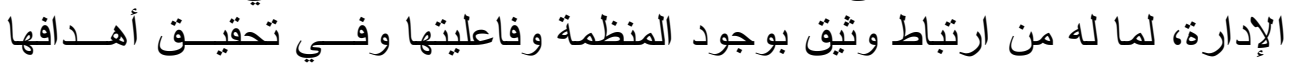

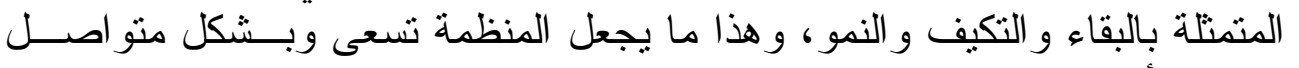

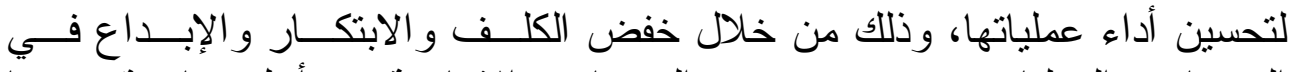

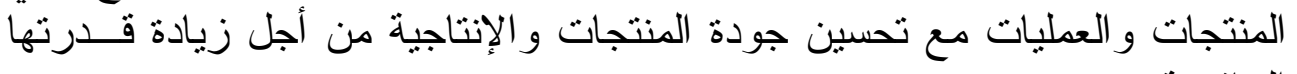

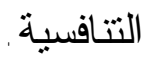

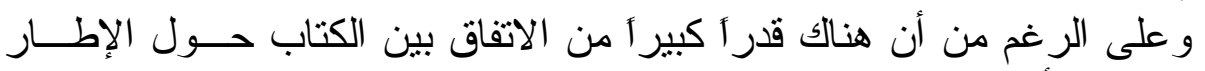

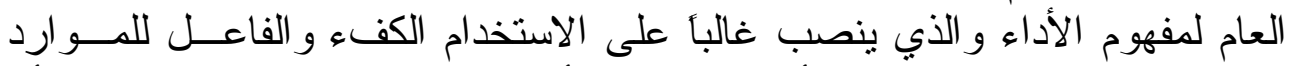

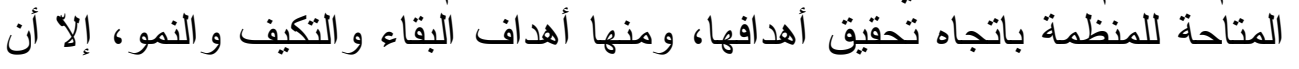

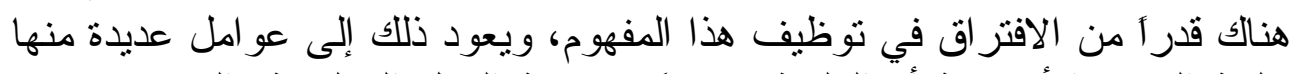

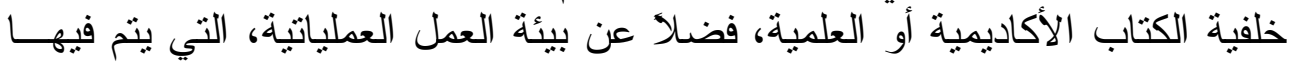

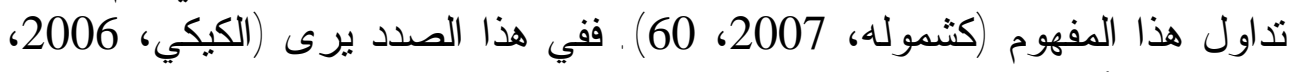

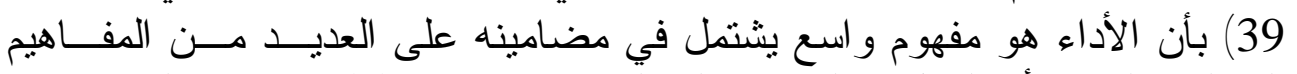

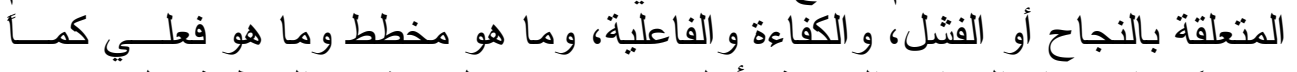

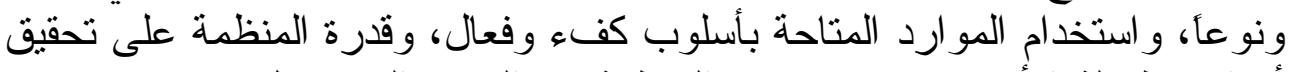

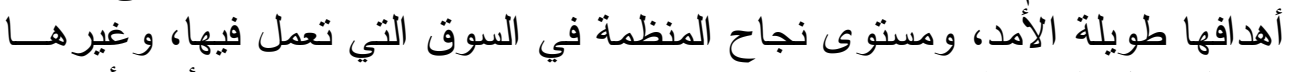

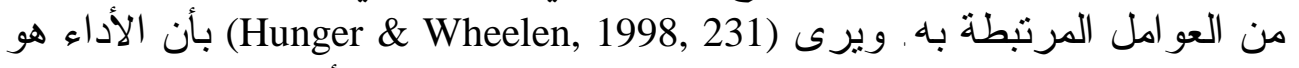

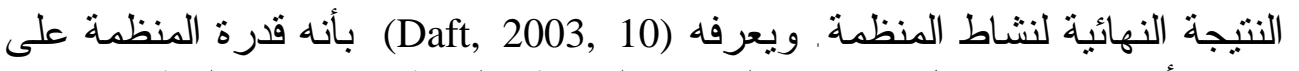

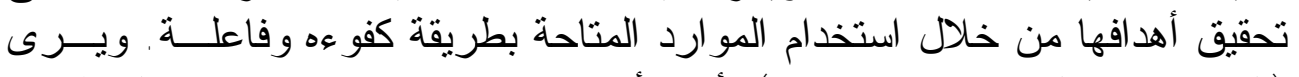

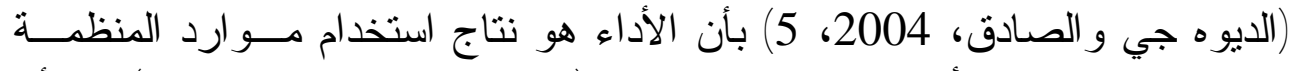

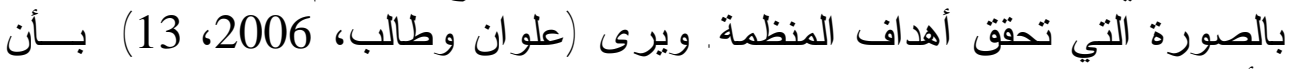

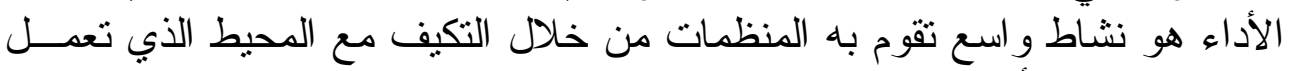

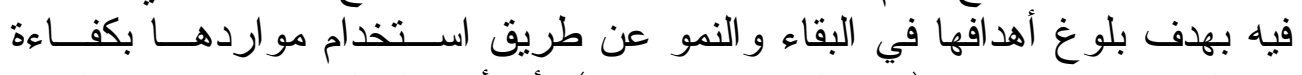

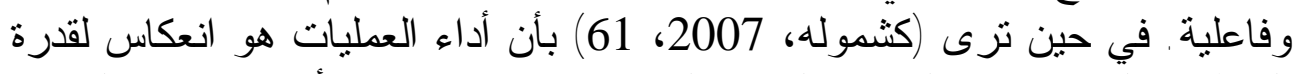

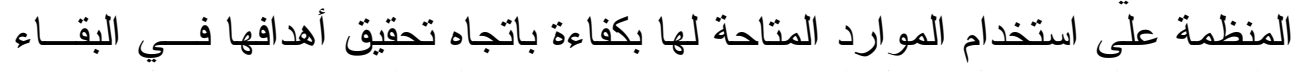

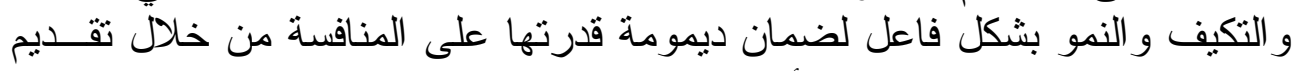

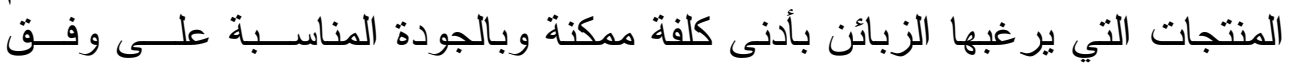

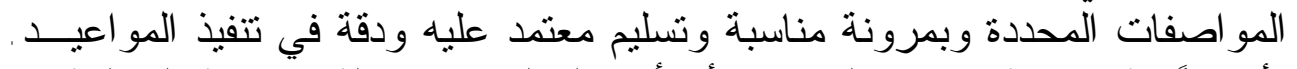

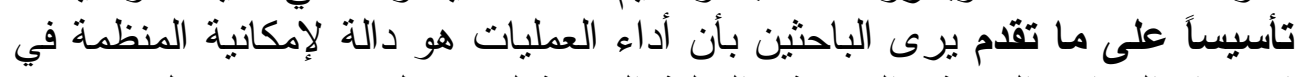

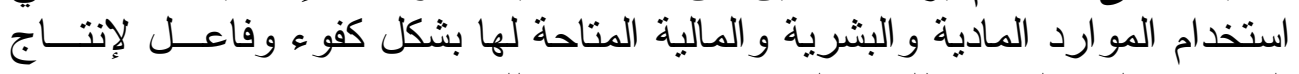

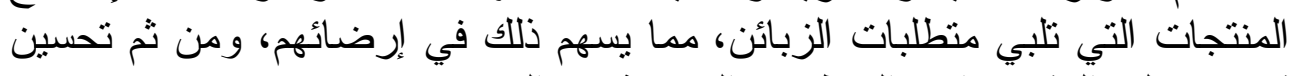

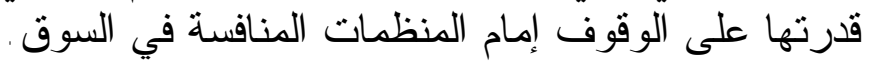


رابعاً - أبعاد أداء العمليات

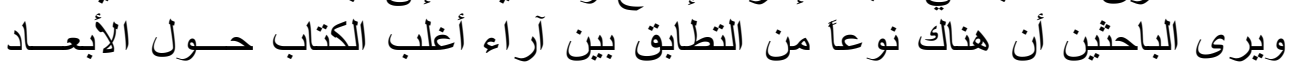

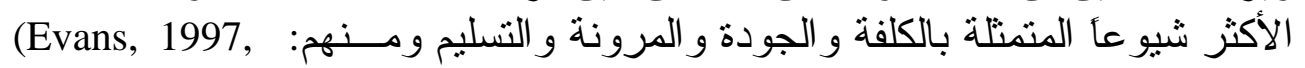
(Slack, et . al, 2004 ,44) (Russell \& Taylor, 2000, 32) 83)

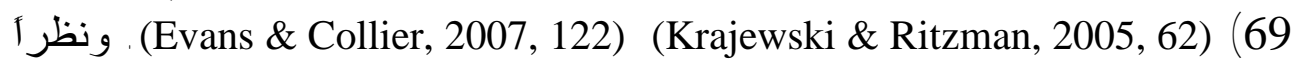
لأهمية هذه الأبعاد في عمل المنظمة، فقد إعتمدها البـاحثين أبعـادآ رئيـسـة ألأداء

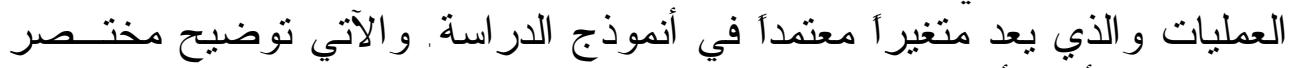

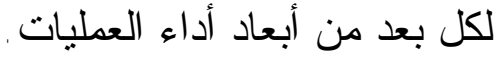

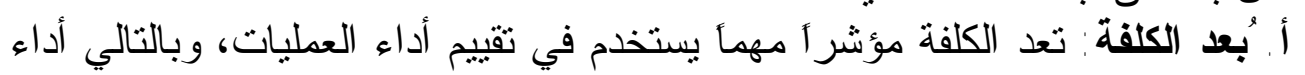

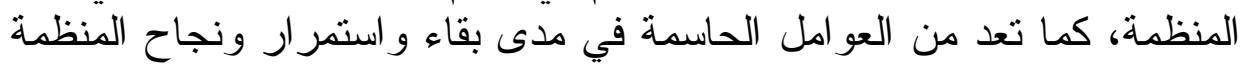

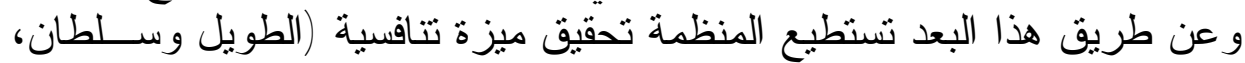
2002، 55). كما تسنطيع المنظمة من خلاع هذا البعد الوقوف أمام المنظمات

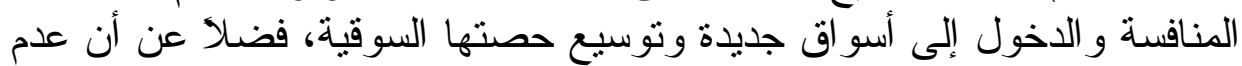

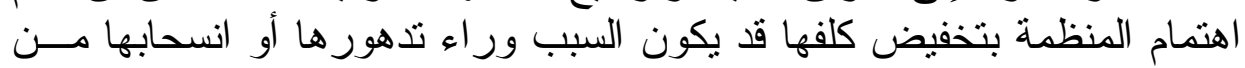

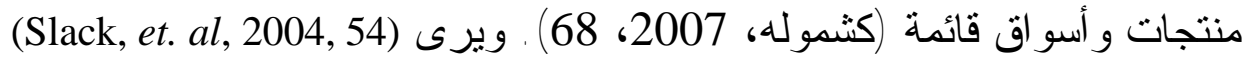

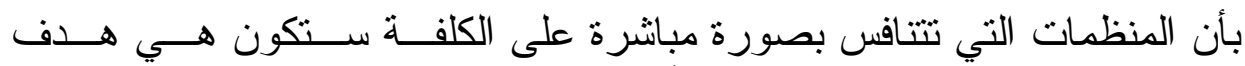

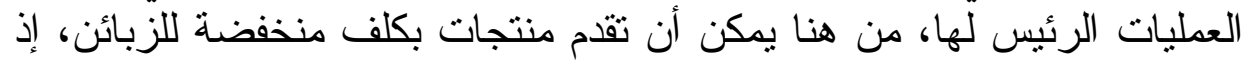

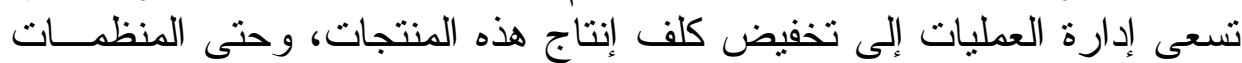

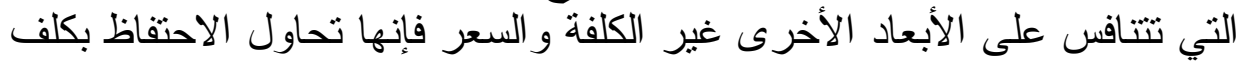

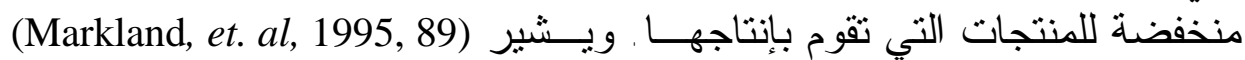

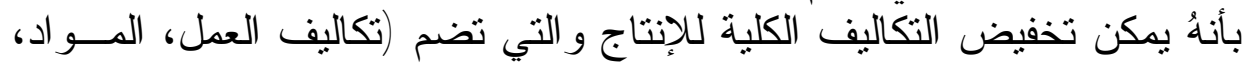

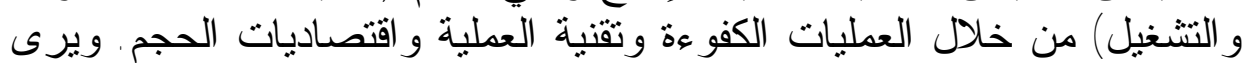
(Russell \& Taylor, 2000, 32) أساس الكلفة التخلص من جميع أنو اع الضياعات، حيث كانت منظمات الأنئ الأعمال

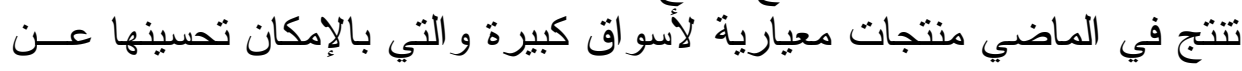

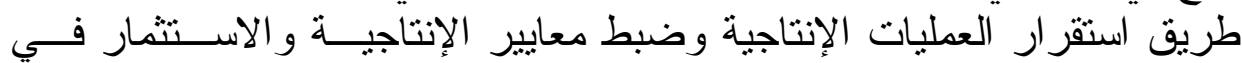

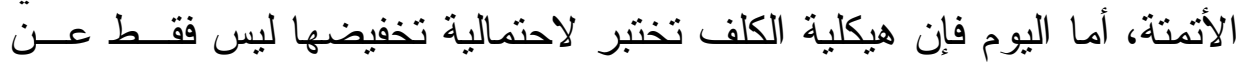

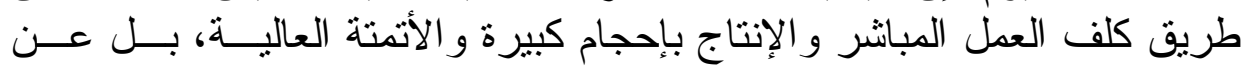

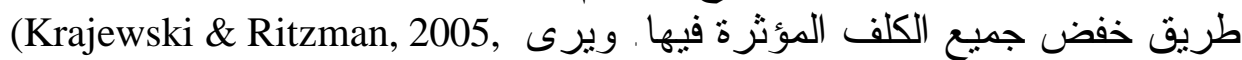

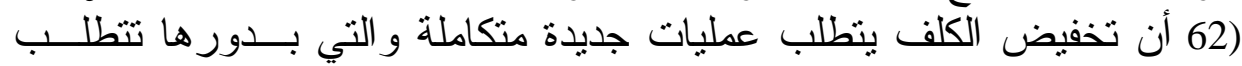

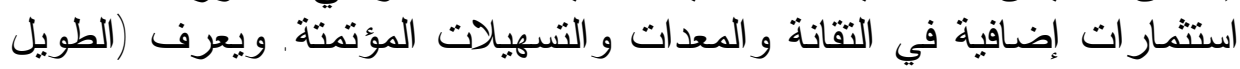

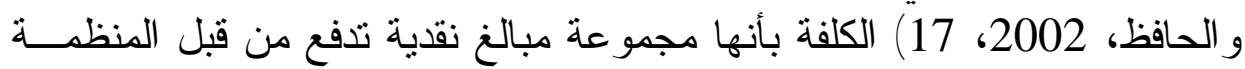




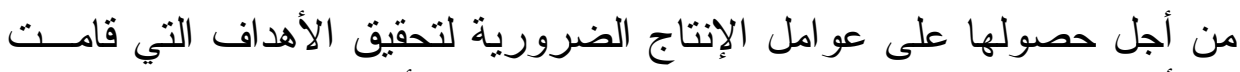
من أجلها المنظمة. ويرى (Slack, et.al, 2004, 54) بأن كلف العملية الإنتاجيــة الإنة

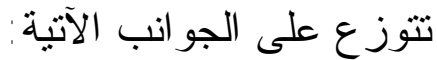
1. كلف القوى العاملة: (هي المال المنفق على الأفر اد العاملين في المنظمة) .

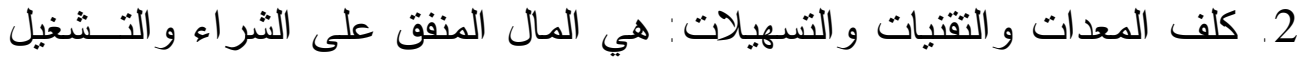

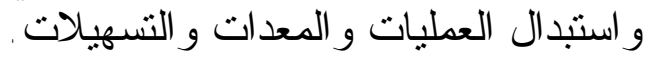
3. كلف المو اد (هي المال المنفق على المواد المستهلكة أو المحولة فــي عمليـات

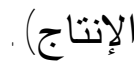

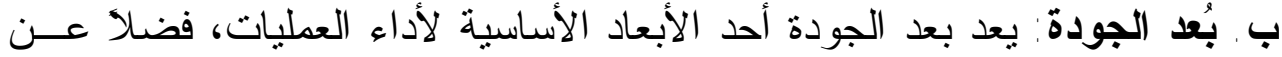

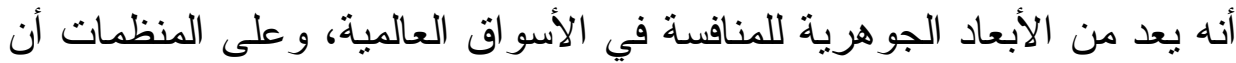

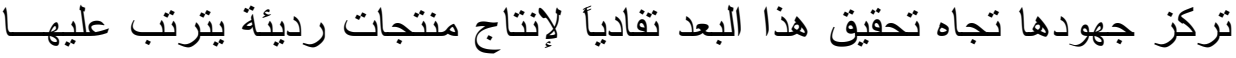

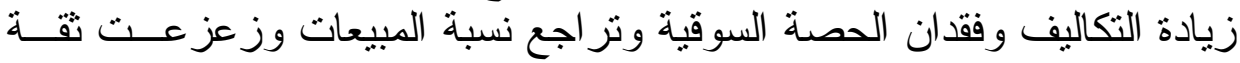

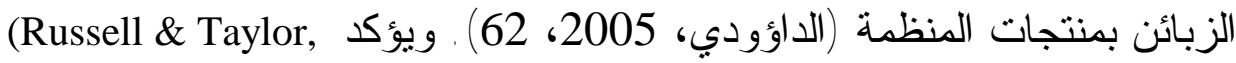

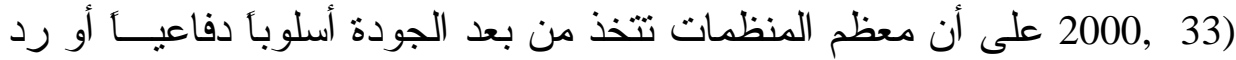

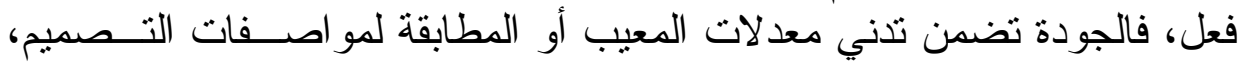

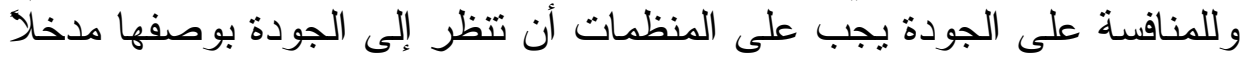

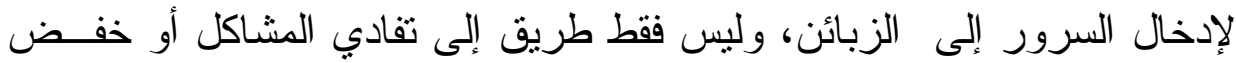

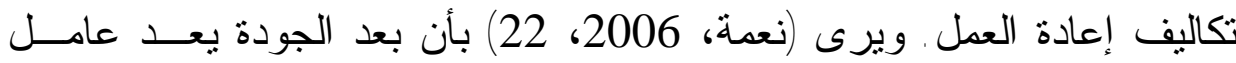

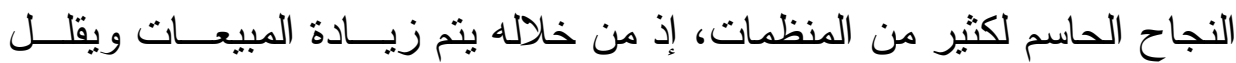

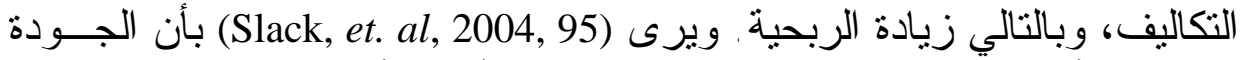

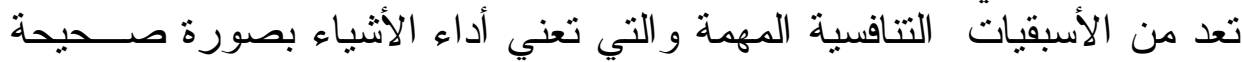

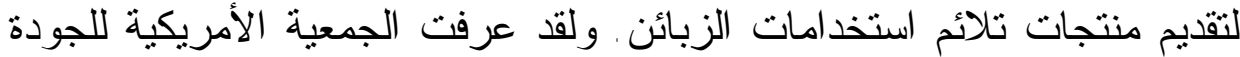
(Heizer \& Render, 1999, 79)

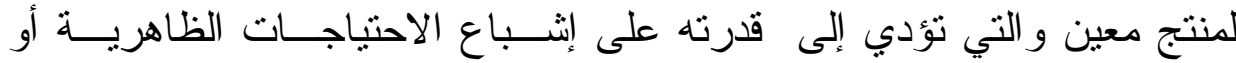

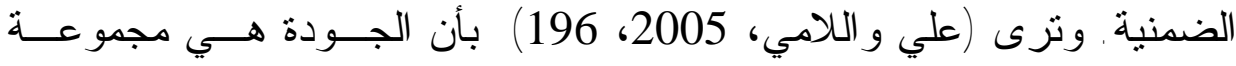

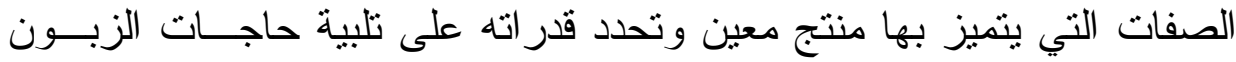

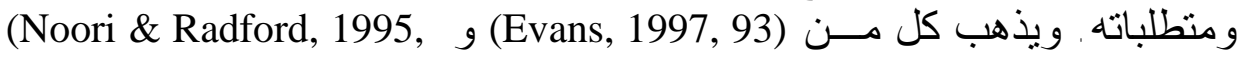

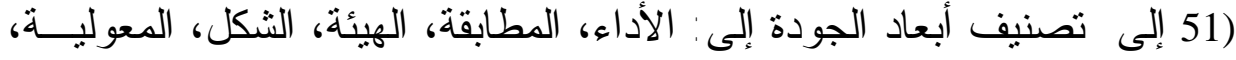

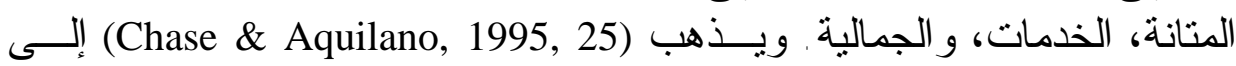
تقسيم الجودة على قسمين جودة المنتج، وجودة العملية، وإن إن مستوى الجودة في

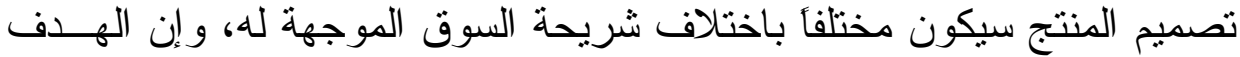

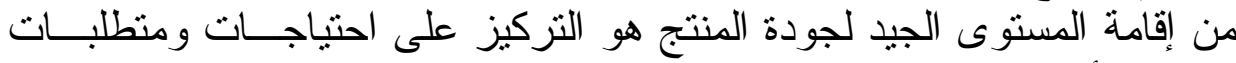

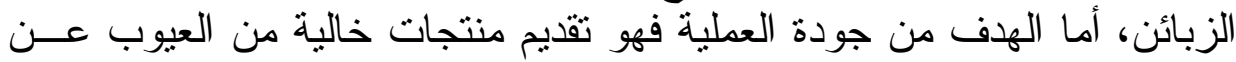

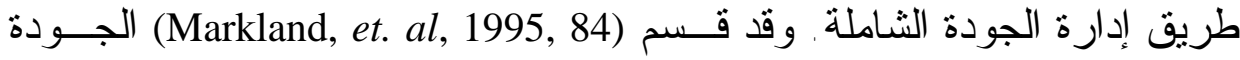
على قسمين جودة المطابقة للمو اصفات (القابلية على تصنيع منتج بخــصائص 
عملياتية لمقابلة معايير الأداء المحددة) وجودة التصميم (القابلية على تقديم منتج

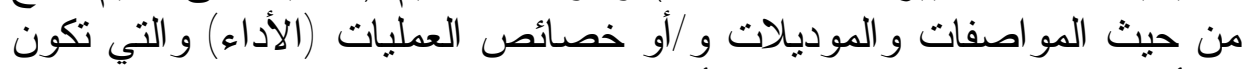

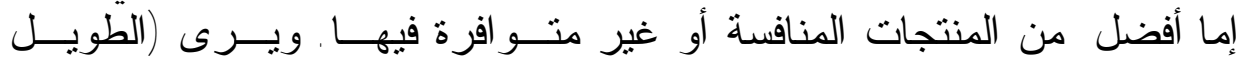

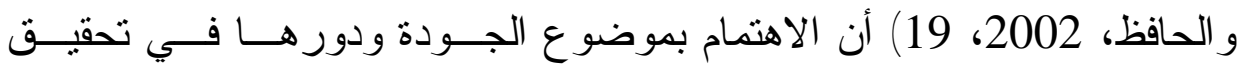

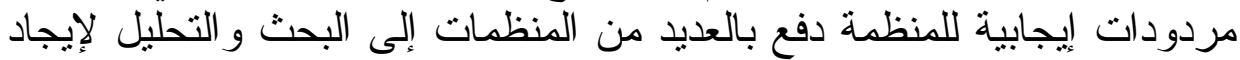

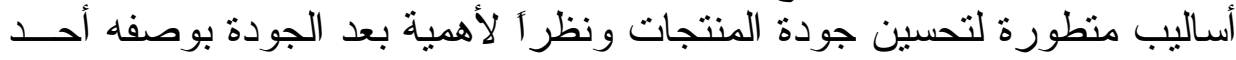

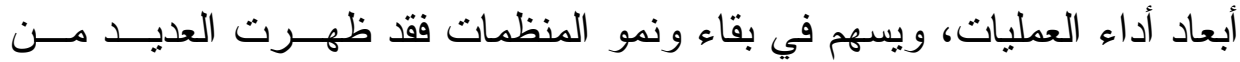

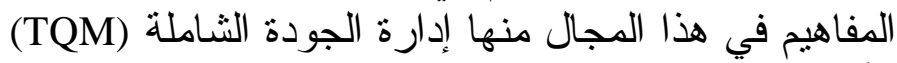

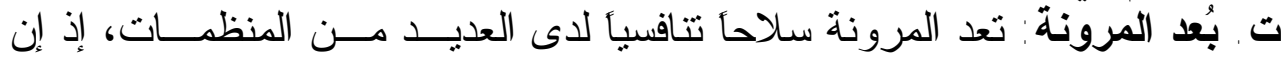

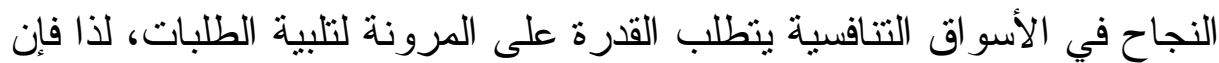

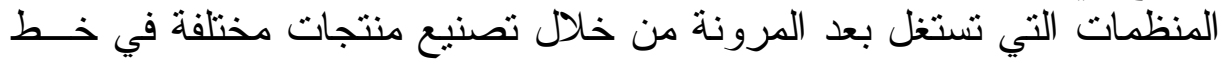
التجميع نفسه وفي الوقت ذاته بمكنها مو اجهة الطلبات المتغيرة، وتنكون فئن فادرة

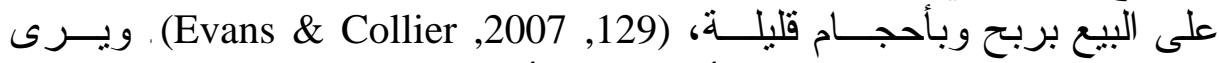
(Russell \& Taylor, 2000, 33)

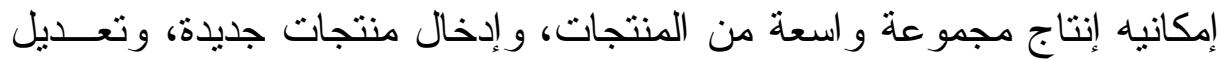

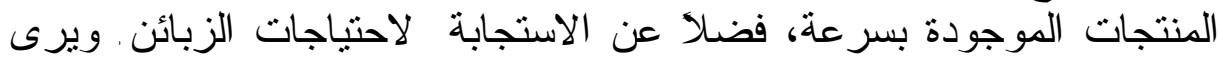
(Chase\& Aquiliano, 1995, 26)

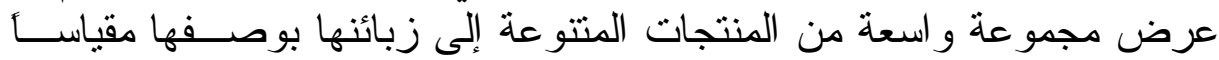

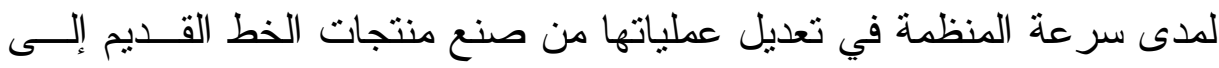

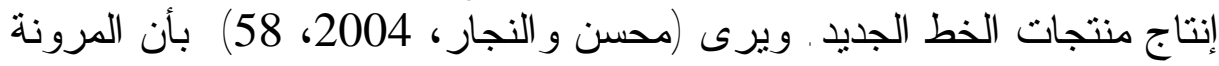

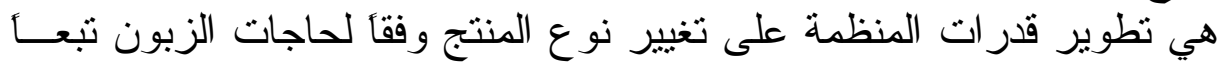

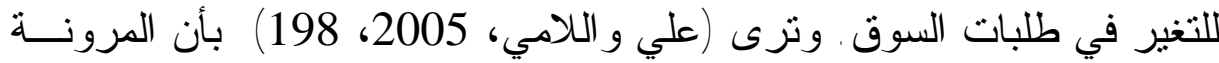

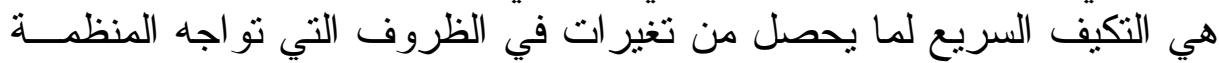

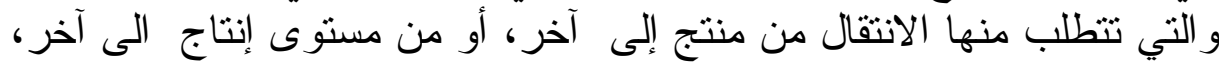

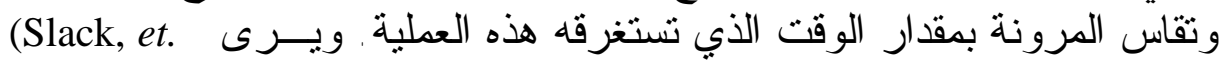

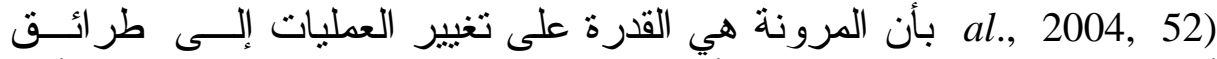

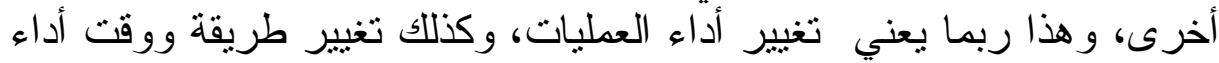

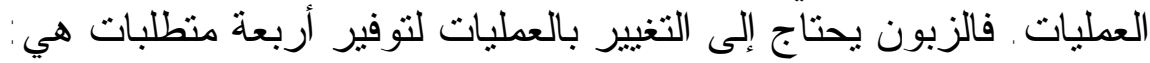
- مرونة المنتج: وهي قدرة العمليات على تقديم منتجات جديدة أو معدلة. - مرونة المزيج: وهي قدرة العمليات على تقديم مدى أو مزيج و واســع مـــن فئن المنتجات .

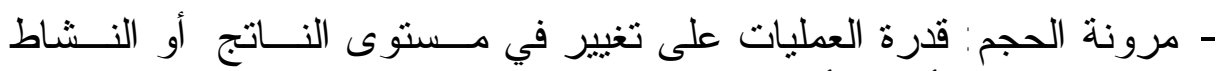

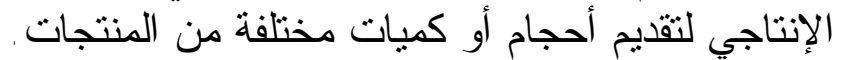
- مرونة التسليم: و هي قدرة العمليات على تغيير أوقات التسليم للمنتجات. 
ويشير (Noori \& Radford, 1995, 53) إلى أن هنالك ثلاثة أنو اع من المرونة وهي: - مرونة المنتج: وتثبير إلى قدرة المنظمة على تقديم منتجات جديدة وتطـــــير

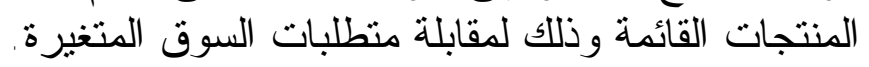

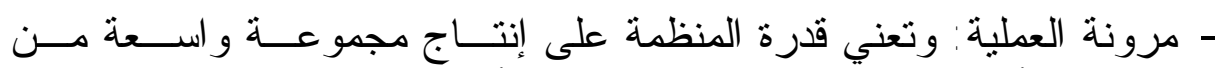

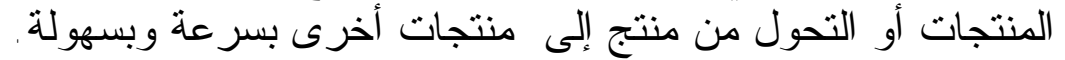

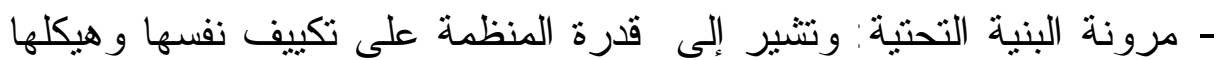

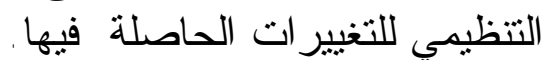

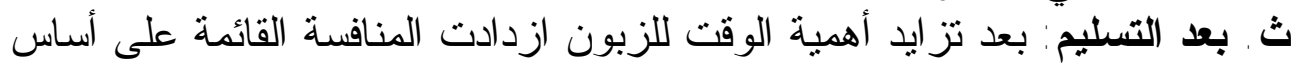

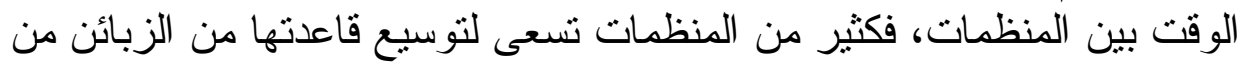

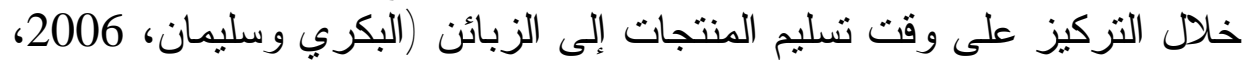

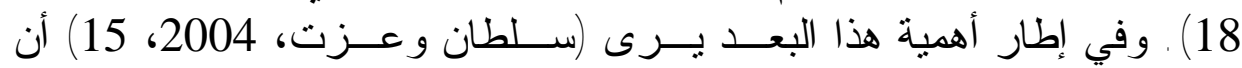

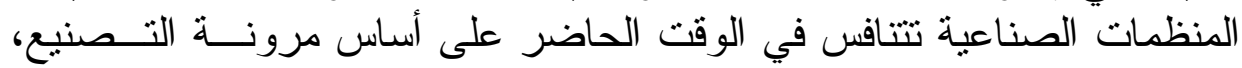

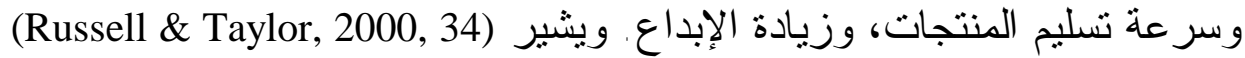

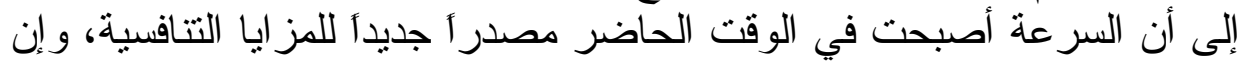

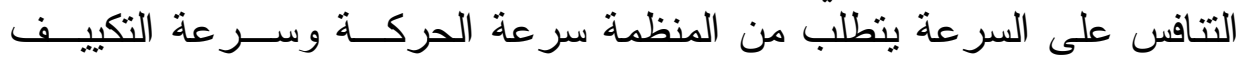

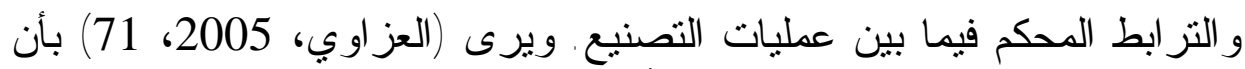

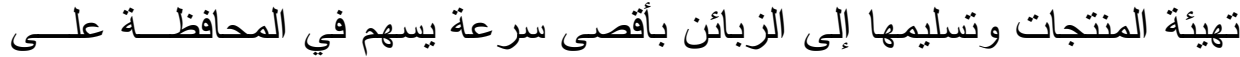

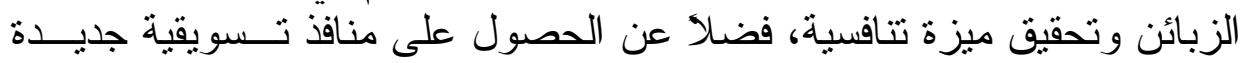

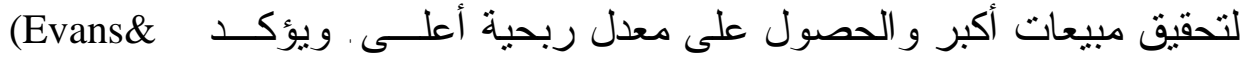
Collier, 2007,126)

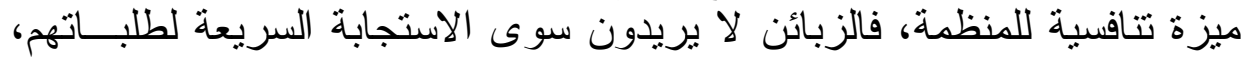

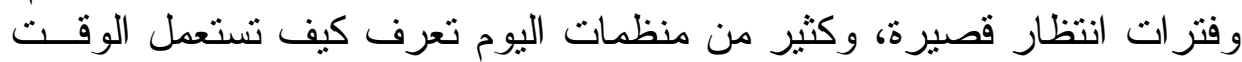

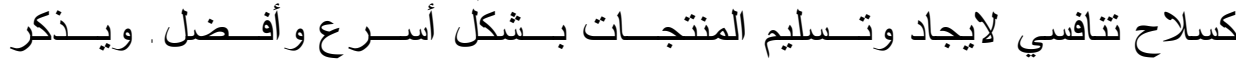
بأن هناك ثلاث أسبقيات لبعـــ التـسليم (Krajewski \& Retzman, 2005, 64) تتعامل بالوقت و هي:

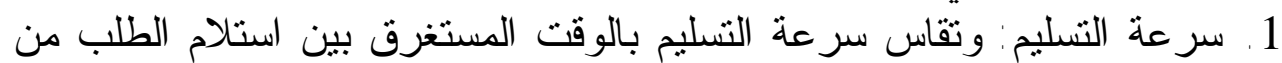

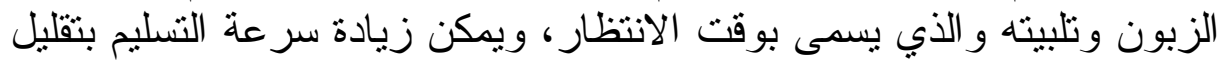

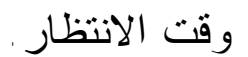
2. التسليم بالوقت المحدد: ويشير إلى تجهيز طلبات الزبائن في الموعد المحـدد لهم من قبل المنظمة.

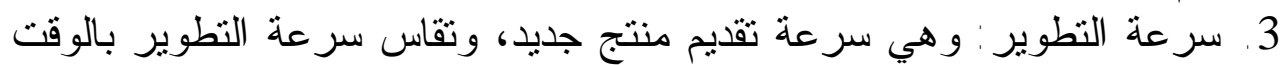

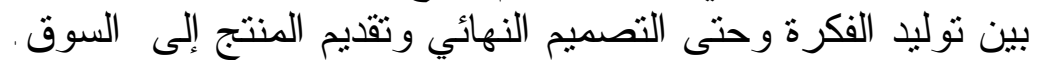

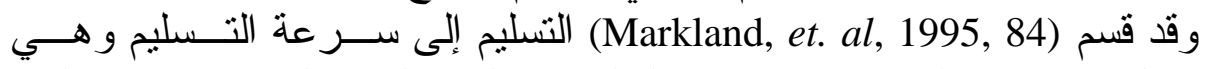

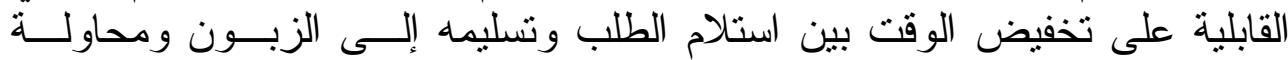


الدكتور الطويل والكيكي [288]

توصيله إلى الصفر قدر الإمكان، و اعتمادية التسليم وهي تعني القابلية على تلبيـــة

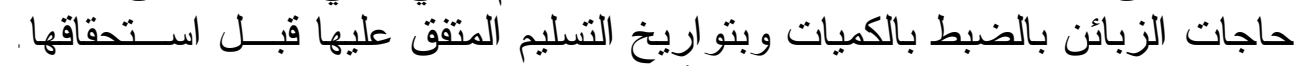

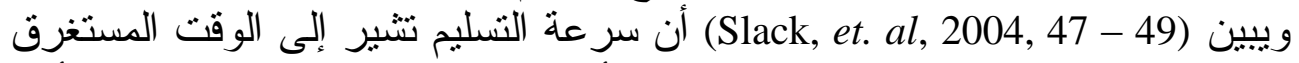

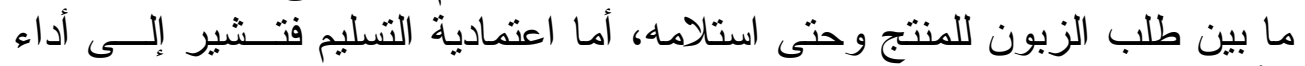

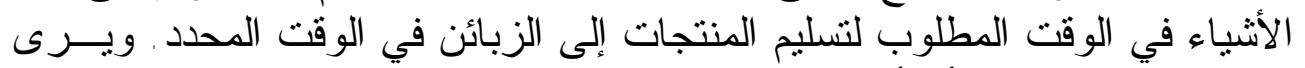
(Evans, 1997, 88) من أهمها: - تمكن المنظمة من تقديم منتجات جديدة فضلا عن تقليص المدة الزمنية لتطــوير - تزتيد من مرونة المنظمة في الاستجابة لحاجات الزبائن المتغيرة باستمر ار ، كما

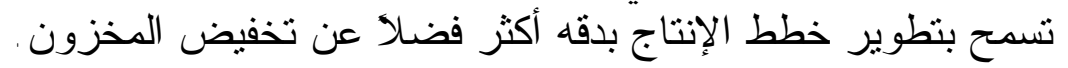

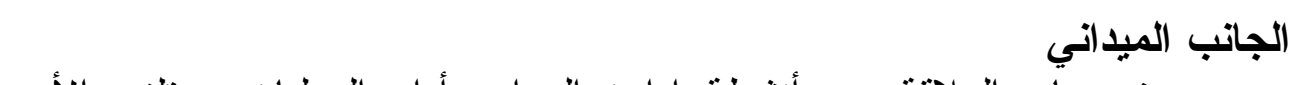
بهدف بيأن العلاقة بين أنشطة إدارة المواد و أداء العمليات يستلزم الأمر

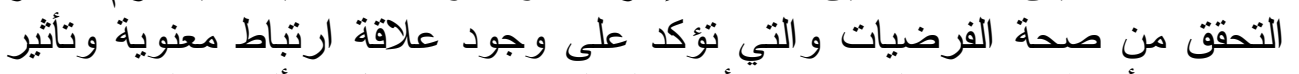

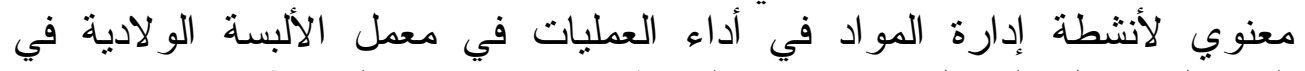

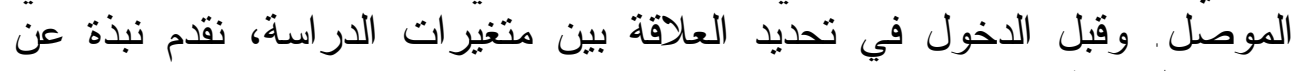
مجتمع الدر اسة و وعينتها.

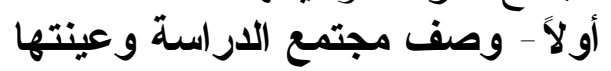

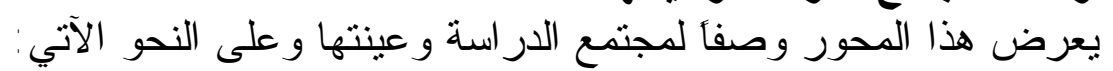

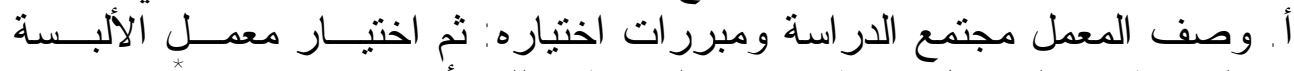

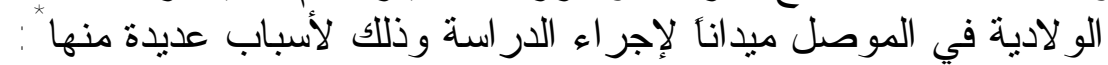

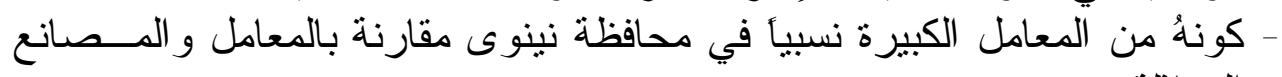
المماثلة. - نتوع أنشطتهِ وتتوع أصناف منتجاته المقدمة للزبائن .

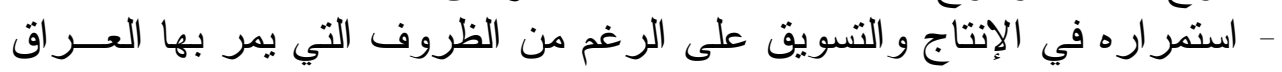
حالياً.

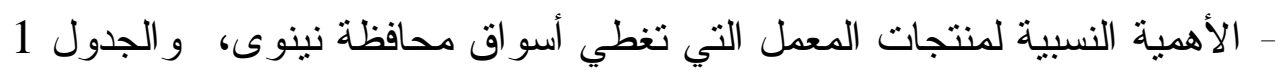
يعطي تعريفاً مبسطا للمعمل قيد الدر اسة. 


\begin{tabular}{|c|c|c|c|}
\hline مناقذ التوزيع & منتجات المعل & نبذة مختصرة عن المعل & 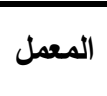 \\
\hline 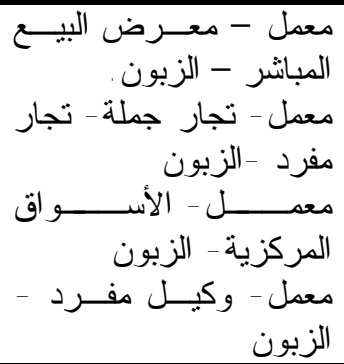 & 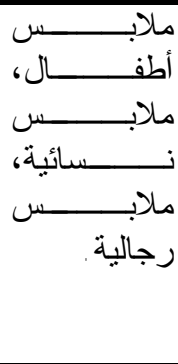 & 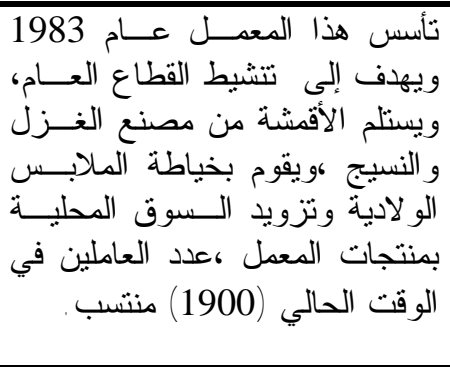 & الألبسة \\
\hline
\end{tabular}

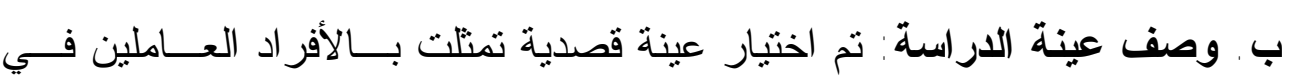

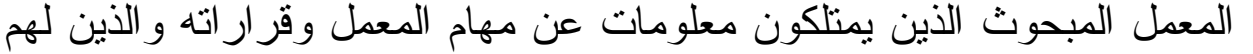

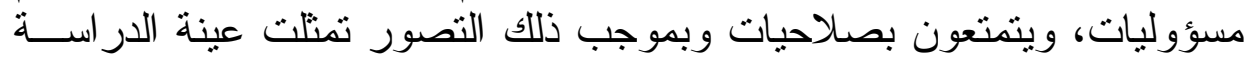

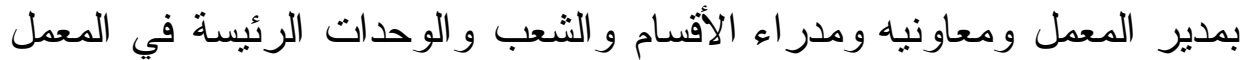

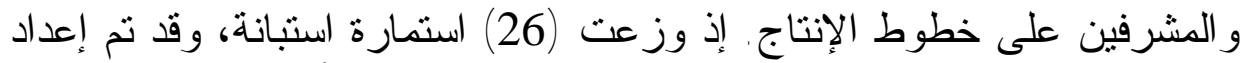

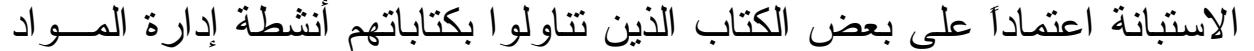

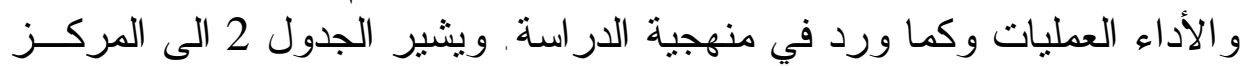

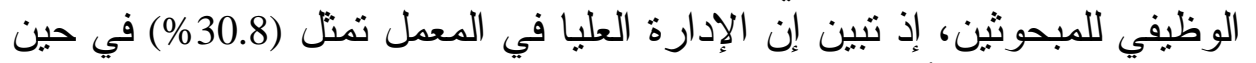
يمنل مدر اء الخط الأول (69.2\%).

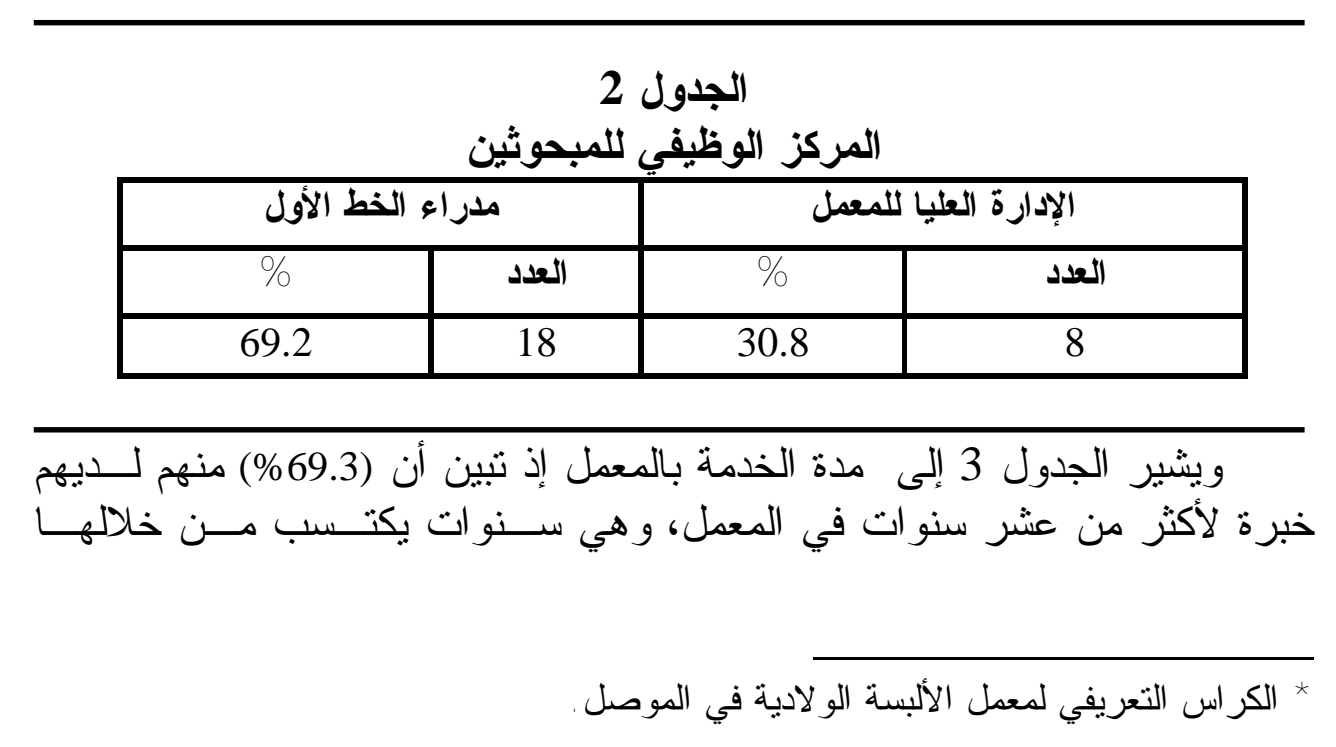




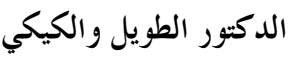

المديرون المعرفة و الخبرة في كيفية اتخاذ القرار ات وكيفية التعامل مع العقبات التي

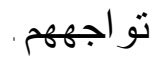

\begin{tabular}{|c|c|c|c|c|c|c|c|}
\hline \multicolumn{8}{|c|}{ مدة الخذمة بالمعمل 3} \\
\hline \multicolumn{2}{|c|}{ 16 - فأكثر } & \multicolumn{2}{|c|}{$15-11$} & \multicolumn{2}{|c|}{$10-6$} & \multicolumn{2}{|c|}{$5-1$} \\
\hline$\%$ & العلدد & $\%$ & العدد & $\%$ & العدد & $\%$ & العلد \\
\hline 46.2 & 12 & 23.1 & 6 & 11.5 & 3 & 19.2 & 5 \\
\hline
\end{tabular}

ويشير الجدول 4 إلى التحصيل الدراسي للمبحوثين وتبين من الجـدول أن (96.1\%) منهم يحملون مؤهلا جيدأ يمكنهم من فهم مكونات الاستبانة و التعامل معها لفيا بشكل صحيح.

\begin{tabular}{|c|c|c|c|c|c|c|c|}
\hline \multicolumn{8}{|c|}{ الجدول 4} \\
\hline \multicolumn{2}{|c|}{ الماجستير } & \multicolumn{2}{|c|}{ البكالوريوس } & \multicolumn{2}{|c|}{ الابلوم } & \multicolumn{2}{|c|}{ الإعدادية } \\
\hline$\%$ & العدد & $\%$ & العدد & $\%$ & العدد & $\%$ & العدد \\
\hline 3.9 & 1 & 84.6 & 22 & 7.6 & 2 & 3.9 & 1 \\
\hline
\end{tabular}

\section{ثانياً - اختبار أنموذج الاراسة وفرضياتها} بهذف النعرف على طبيعة العلاقة بين أنشطة إدارة المواد ادو و أداء العطليات في

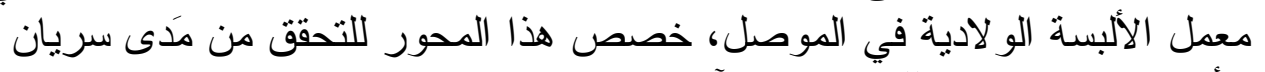

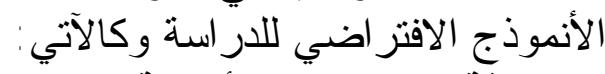

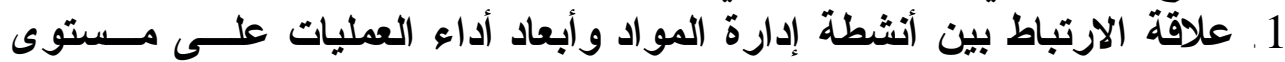

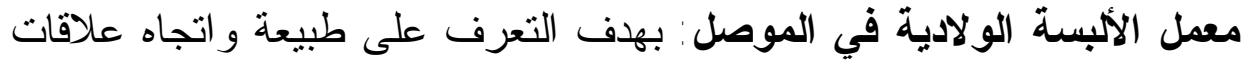

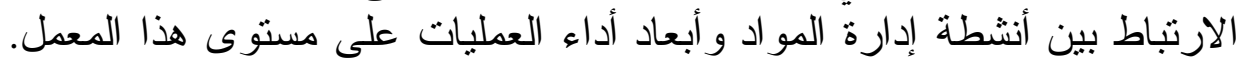

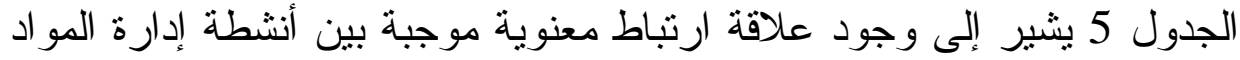

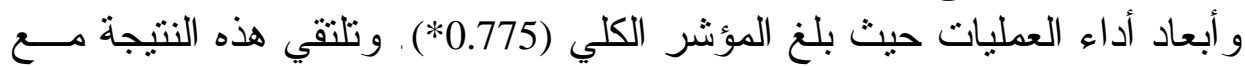

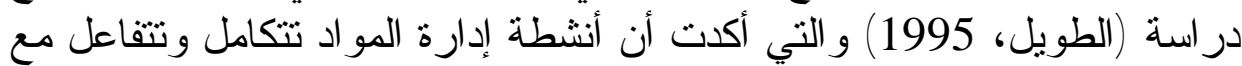

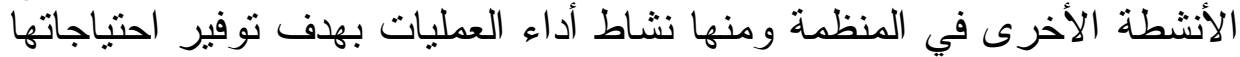

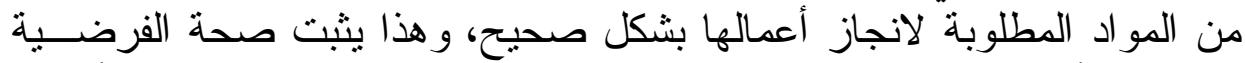

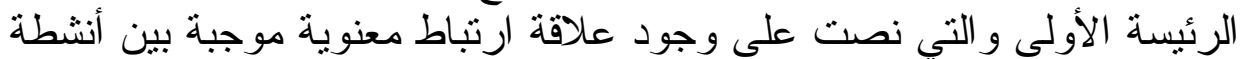

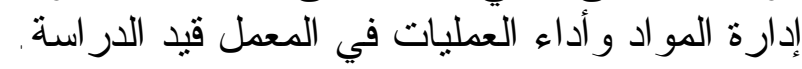




\section{الجدول 5}

نتائج علاقات الارتباط بين النشطة إدارة المواد وأبعاد أداء العمليات على مستوى الأبى

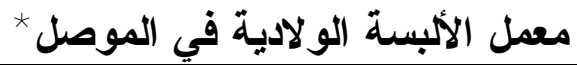

\begin{tabular}{|c|c|c|c|c|c|c|}
\hline \multirow{2}{*}{ الكوئشر } & \multicolumn{4}{|c|}{ أبعاد أداء العمليات } & \multirow{2}{*}{\multicolumn{2}{|c|}{ المتغيرات المتثلة }} \\
\hline & \multirow{2}{*}{ التسليم } & \multirow{2}{*}{ المرونة } & \multirow{2}{*}{ الجودة } & \multirow{2}{*}{ الكلقة } & & \\
\hline & & & & & الشراء الشراء & 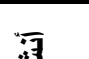 \\
\hline & $* 0.549$ & 0.369 & $* 0.574$ & $* 0.549$ & النقل & 赵 \\
\hline & 0.364 & $* 0.554$ & $* 0.442$ & $* 0.682$ & الفحص والاستلام & 5 \\
\hline & $* 0.479$ & $* 0.724$ & $* 0.548$ & $* 0.535$ & التخزين & $\frac{3}{7}$ \\
\hline$* 0.775$ & $* 0.676$ & $* 0.698$ & $* 0.597$ & $* 0.738$ & المؤشر الكلي & \\
\hline
\end{tabular}

وبهدف إعطاء مؤشر ات تفصيلية بين أنشطة إدارة المو اد و أبعاد أداء العمليات

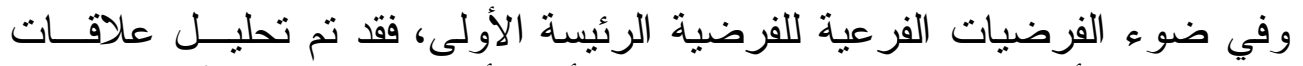

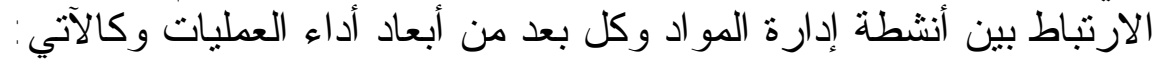

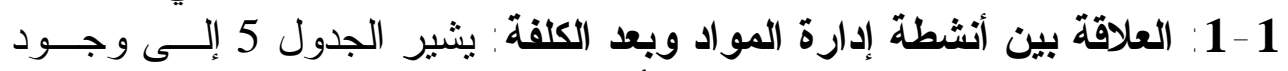

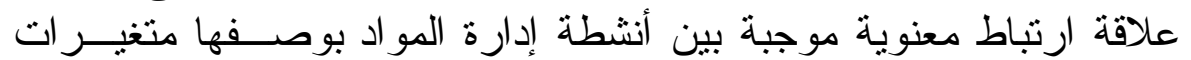

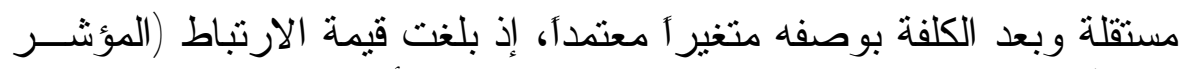

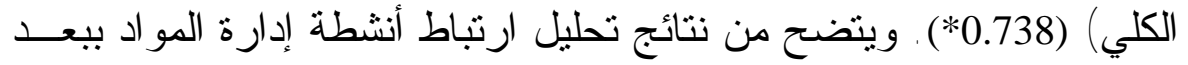

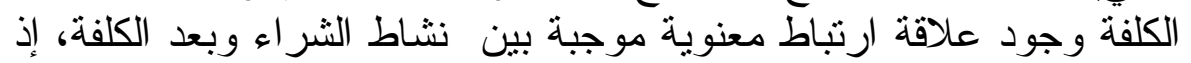

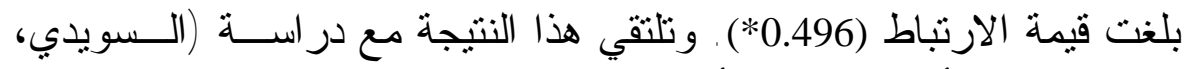

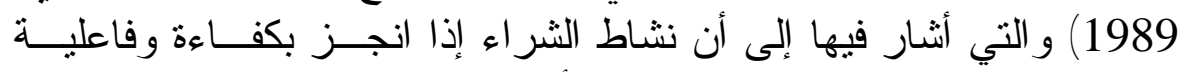

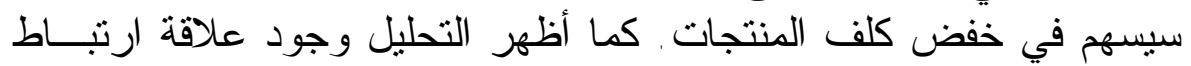

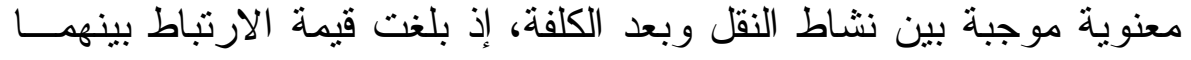
(0.549*) ). وتتفق هذا النتيجة مع در اسة (عبد الرحمن، 2001) و التي تشير

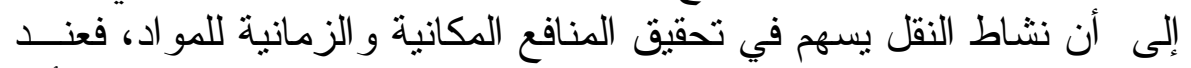

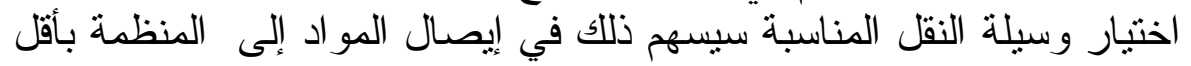

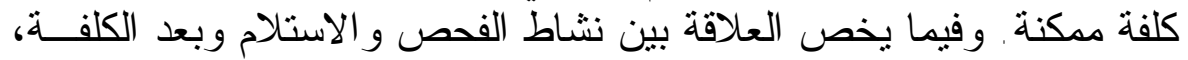

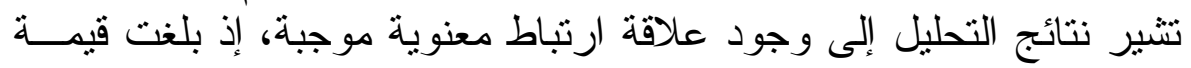




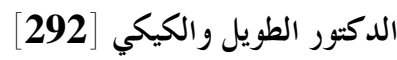

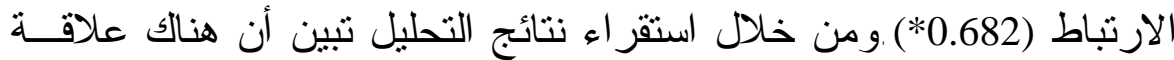

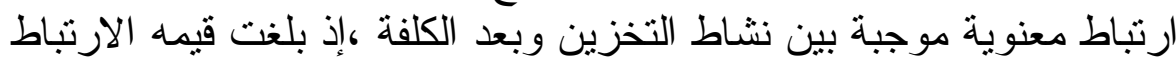

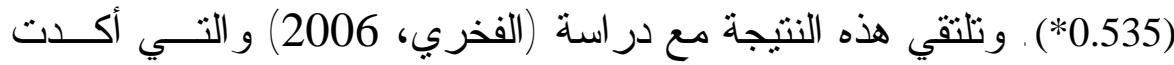

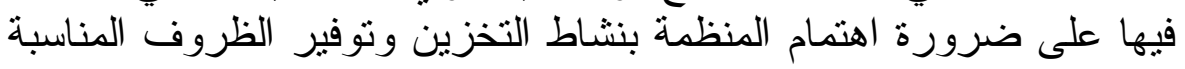

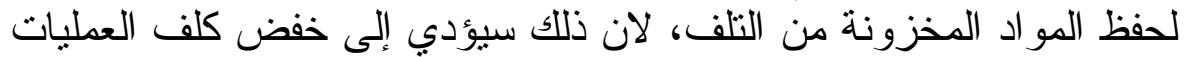

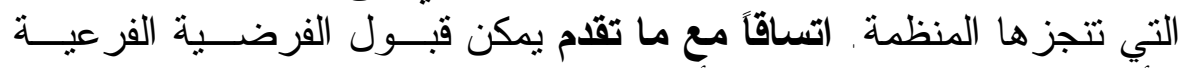
الأولّى من الفرضية الرئيسة الأولى العئ.

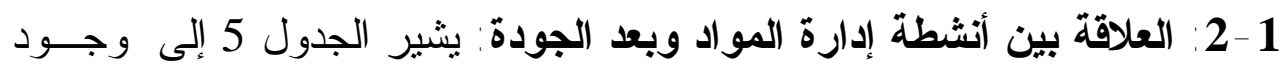

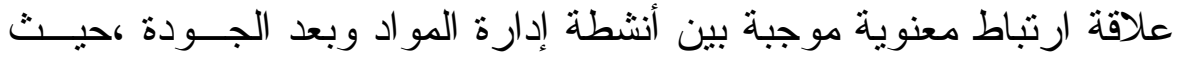

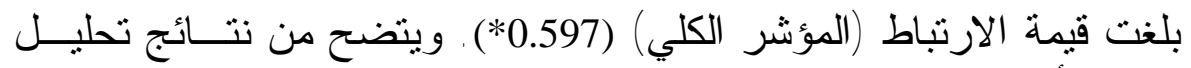

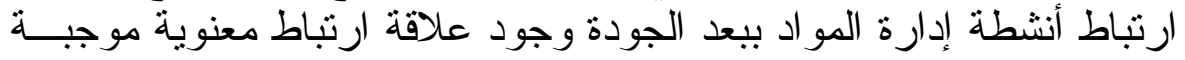

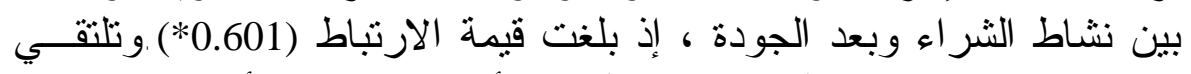

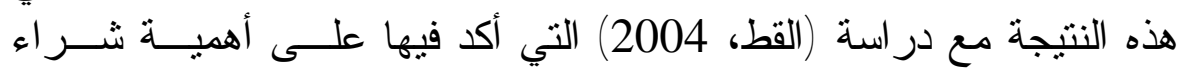

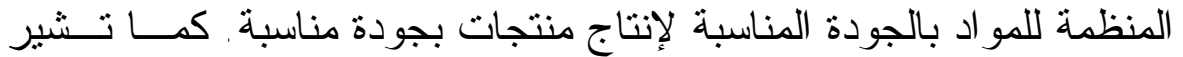

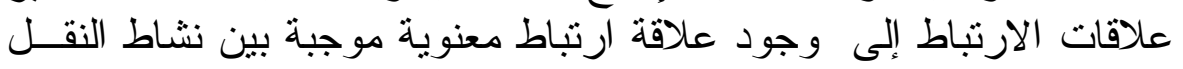

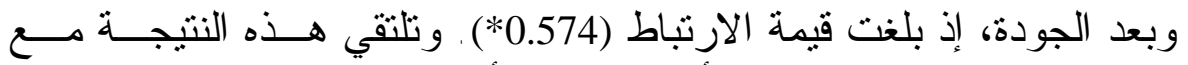

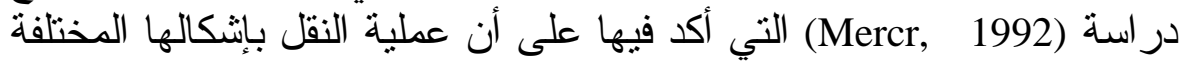

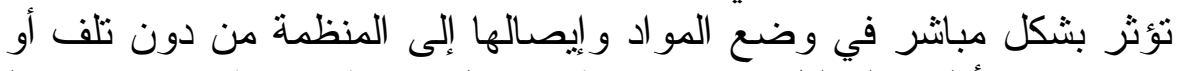

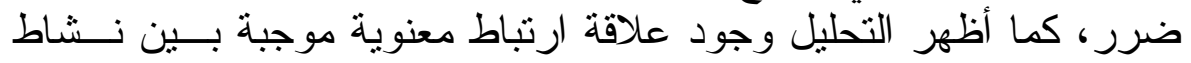

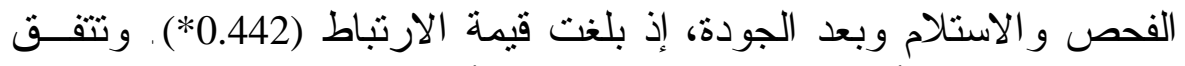

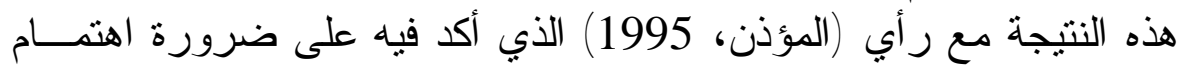

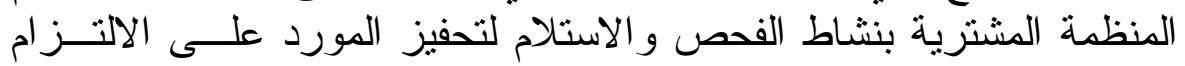

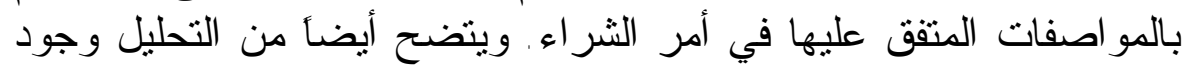

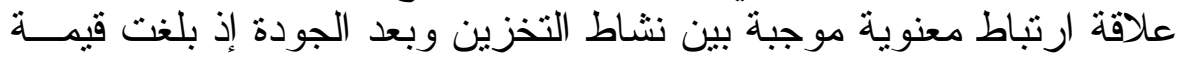

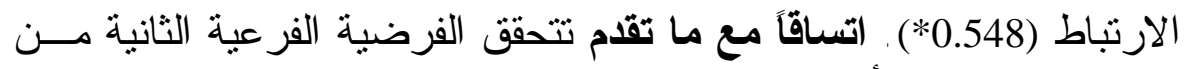

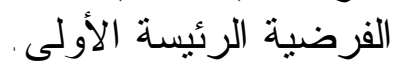

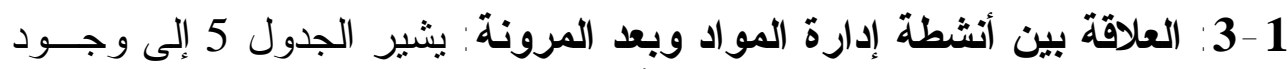

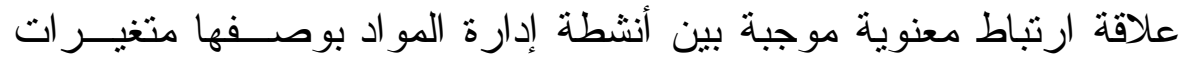

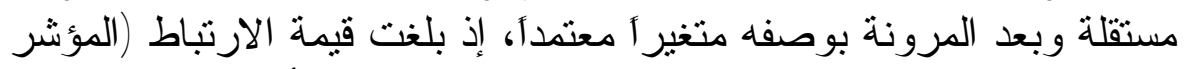

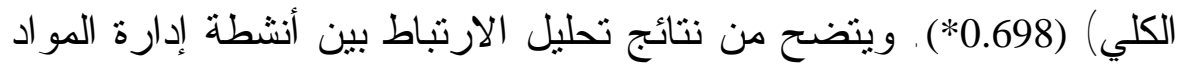

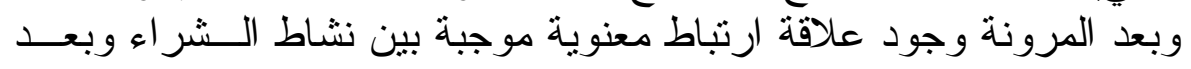

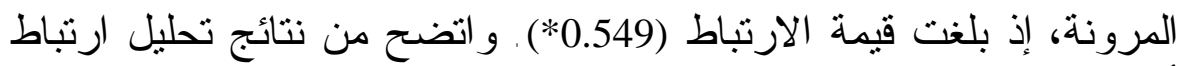

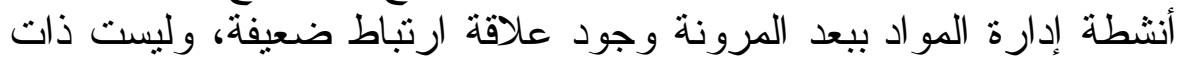

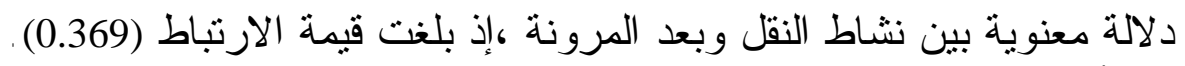

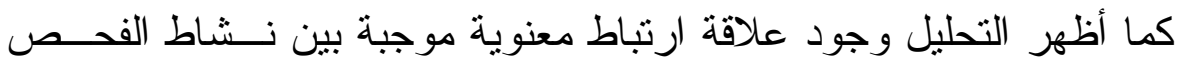




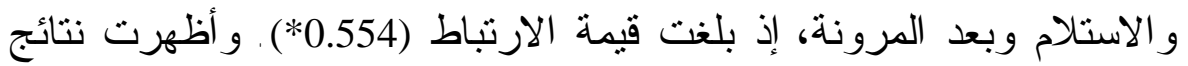

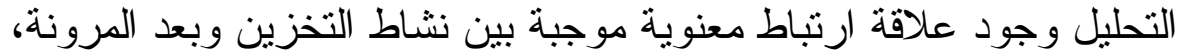

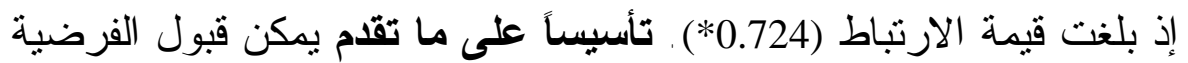

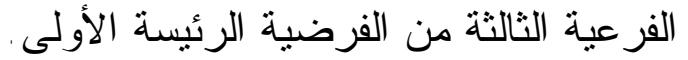

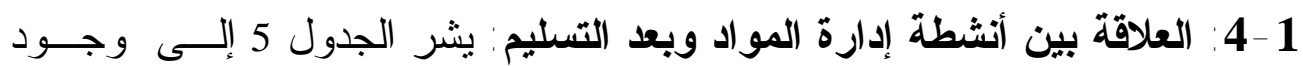

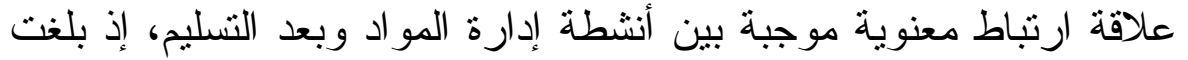

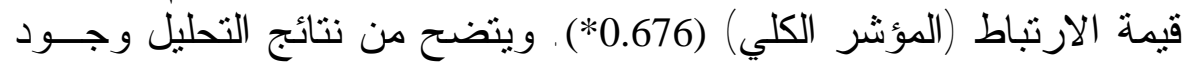

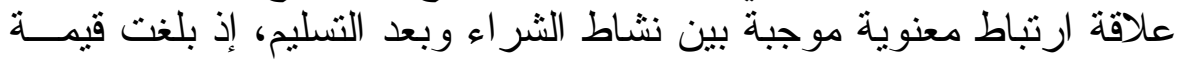

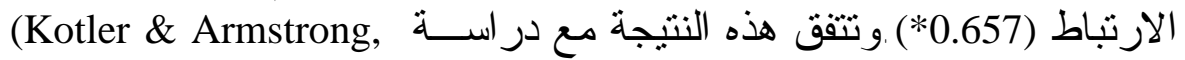

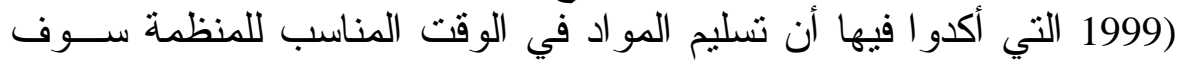

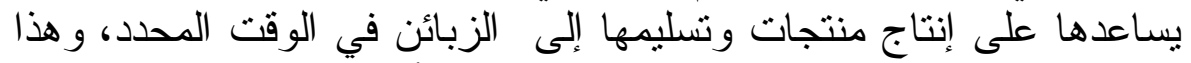

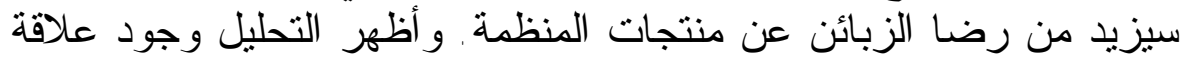

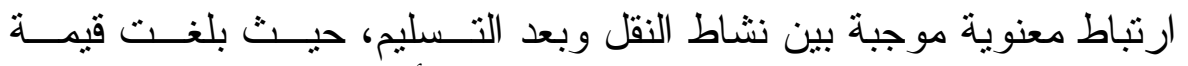

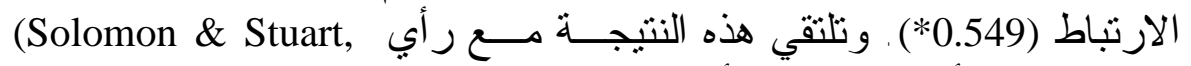

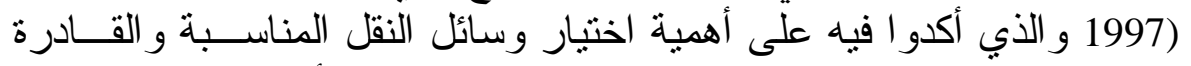

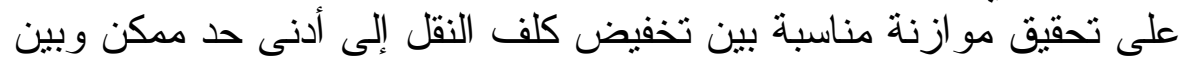

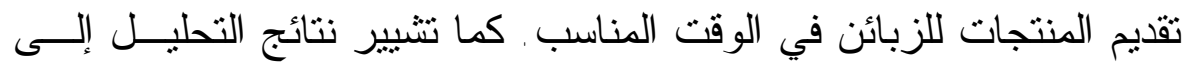

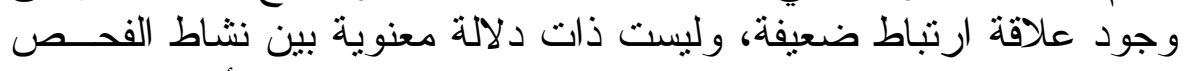

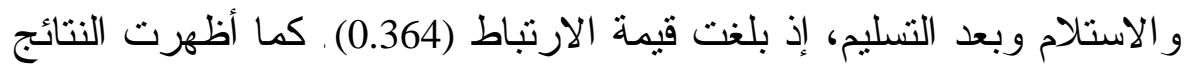

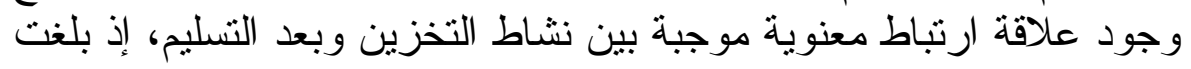

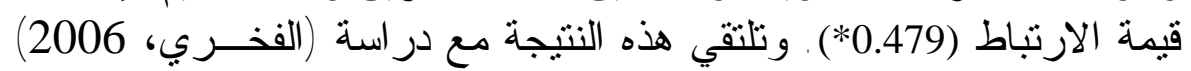

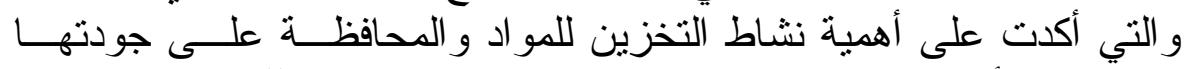

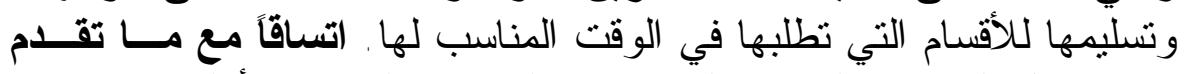

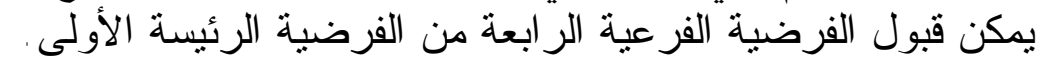

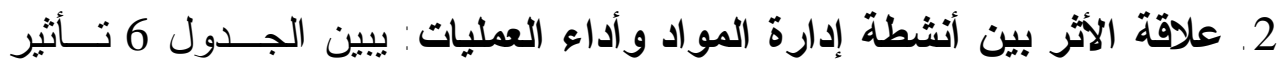

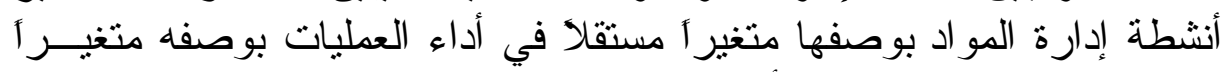

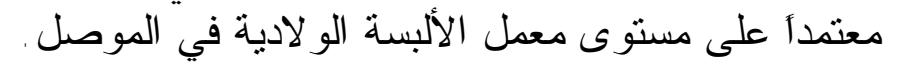

\section{الجدول 6}

تأثير أنثطة إدارة المواد في أبعاد أداء العمليات على مستوى معمل الألبسة * الولادية في الموصل

\begin{tabular}{|c|c|c|c|c|c|}
\hline \multicolumn{2}{|c|}{$\mathbf{F}$} & \multirow{2}{*}{$\mathbf{R} 2$} & \multicolumn{2}{|c|}{ أنثنطة إدارة المواد } & 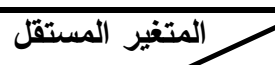 \\
\hline الجذولية & المحسوبة & & $\overline{\mathbf{B}_{1}}$ & $\overline{\mathbf{B}_{0}}$ & \\
\hline 4.25 & $* 36.05$ & $\overline{0.60}$ & $\begin{array}{r}1.12 \\
*(6.04) \\
*\end{array}$ & 0.71 & أبعاد أداء العمليات \\
\hline
\end{tabular}


[294] الدكتور الطويل والكيكي [20]

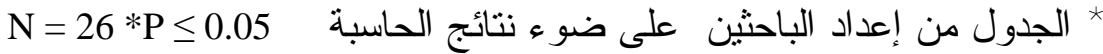

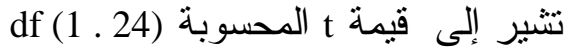

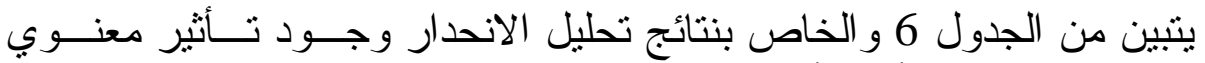

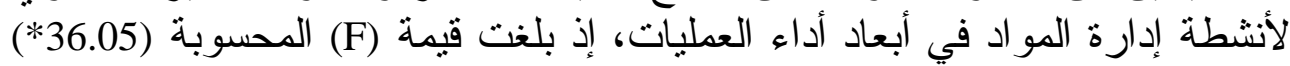

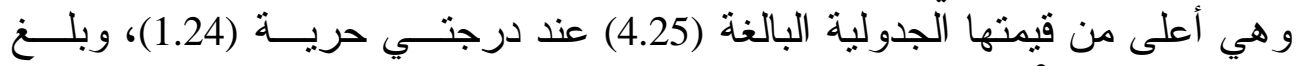

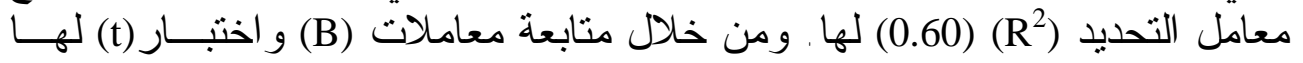

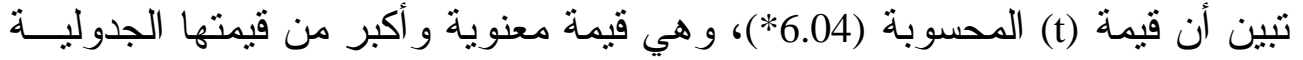

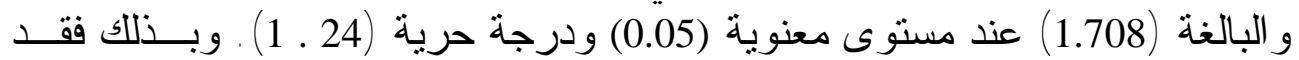

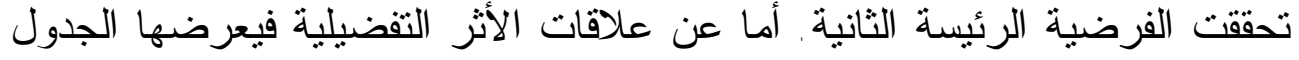

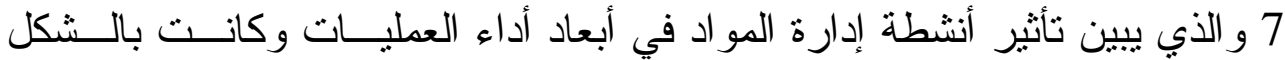

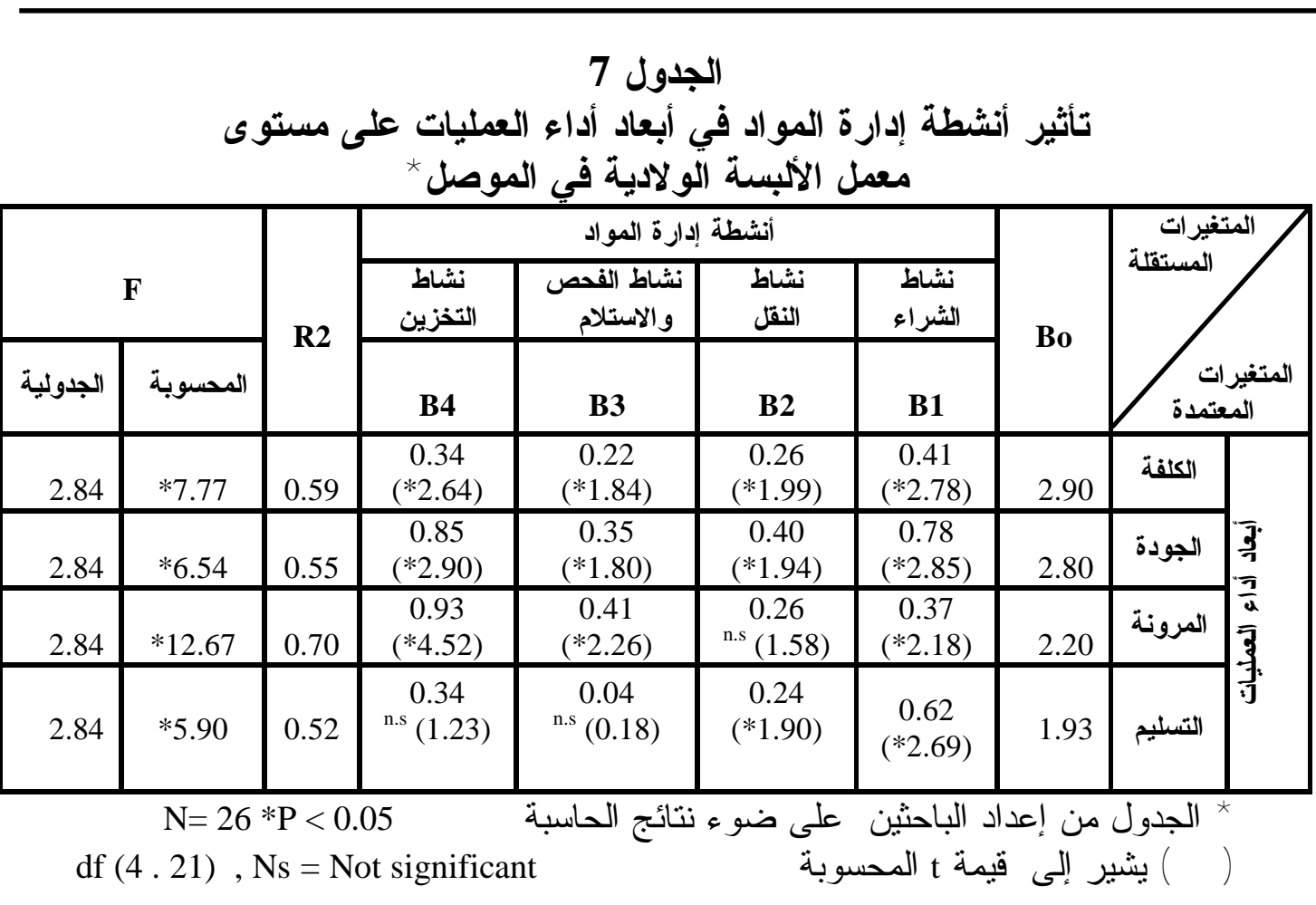

2 -1: تأثير أنثطة إدارة المواد في بعد الكلفة: يتضح من الجدول 7 وجود تأثير

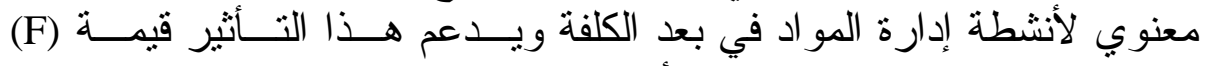
المحسوبة و البالغة (7.77*)، وهي أكبر من فيمتها الجدولية البالغة (2.84) عند وند

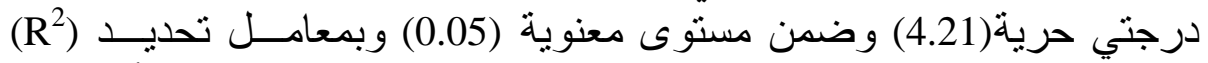
قدرة (0.59). ومن خلال متابعة معاملات (B) ورى (1) واختبار (t) لها وجد أنه هنالك 
نأثير معنوي لكل نشاط من أنشطة إدارة المو اد في بعد الكلفة. ويتضح لنا من

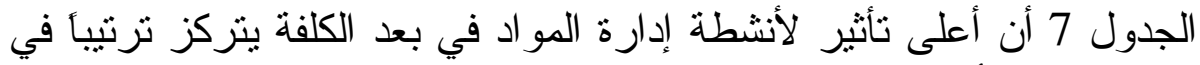

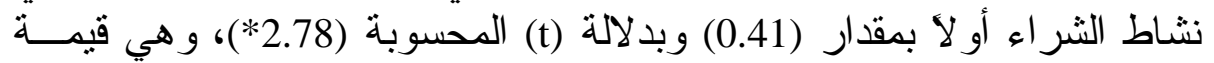

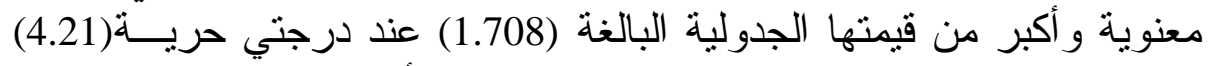

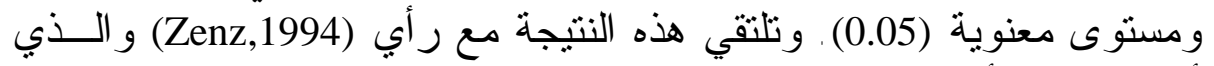

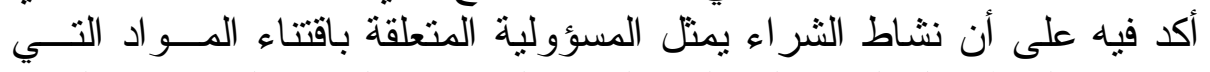

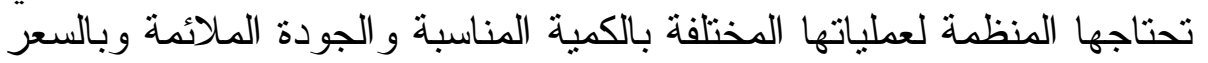

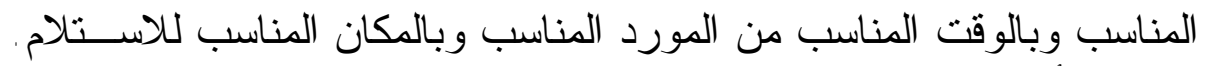
ثم جاء تأثير نشاط التخزين في بعد الكلفة في المرنبة الثانية بمقــدار (0.34)

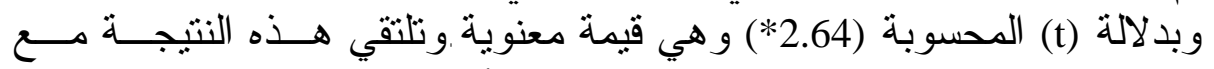

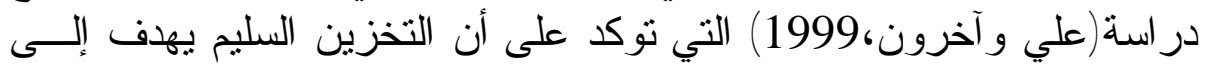

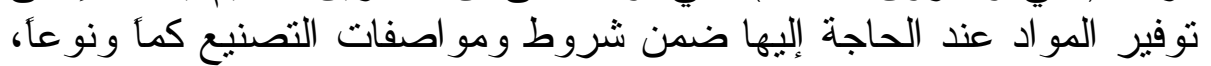

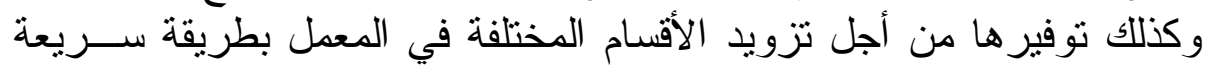
وتكاليف قليلة ثث جاء تأثير نشاط النقل بالمرتبة الثالثثة وبمقدار (0.26) وبدلالة

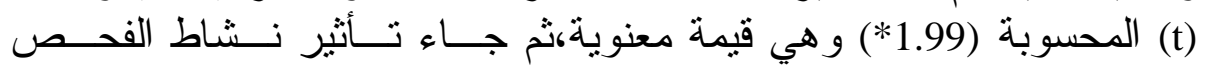

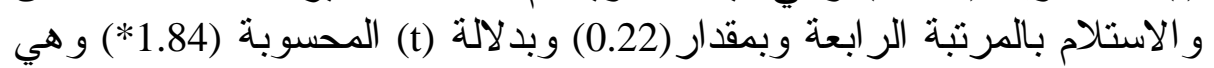

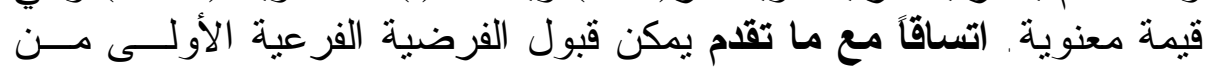
الفرضية الرئيسة الثانية. 2 -2: تأثير أنشطة إدارة المواد في بعد الجودة: بتضح من الجدول 7 وجود تأثير

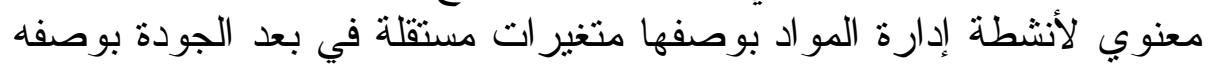

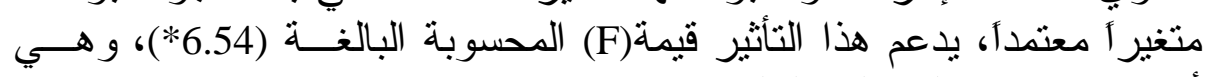

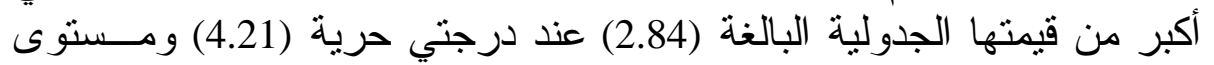

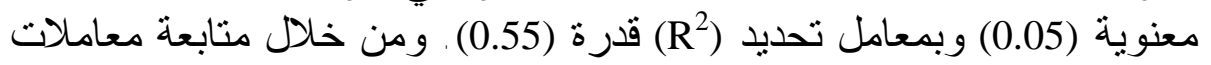

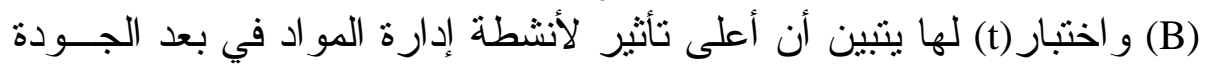

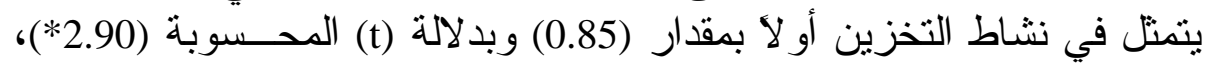

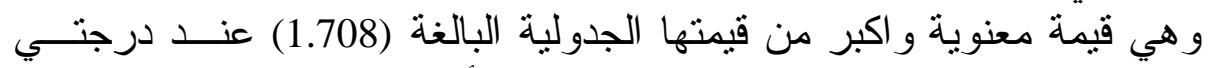

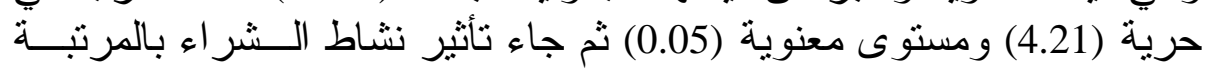

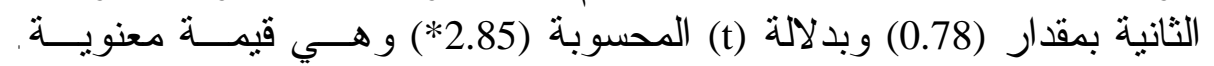

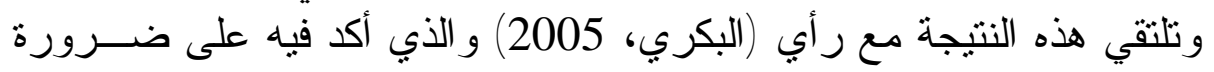

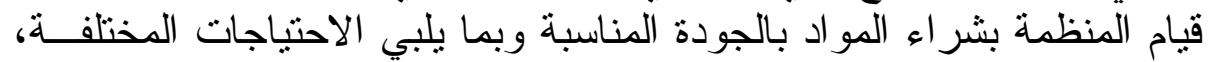

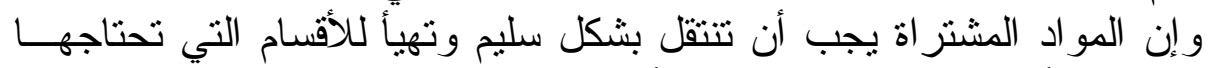

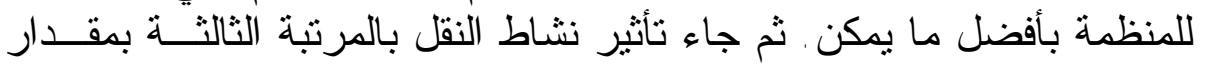

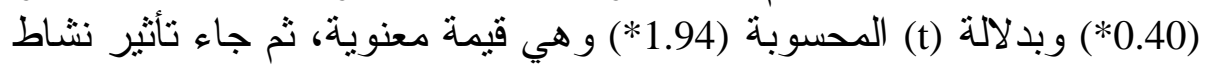

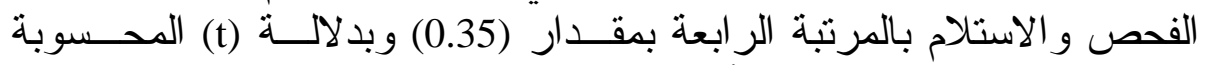

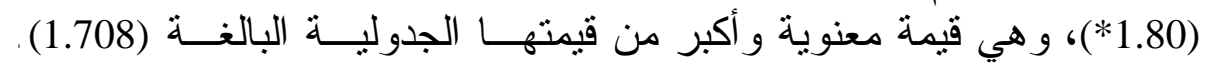




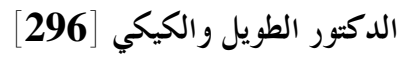

تأسيساً على مـا تقدم يمكن قبول الفرضية الفرعية الثانيــة مــن الفرضــية الرئيسة الثانية . تائيا

2 -3: تأثير أنشطة إدارة المواد في بعد المرونــة : يوضح الجدل 7 وجود تــأثير

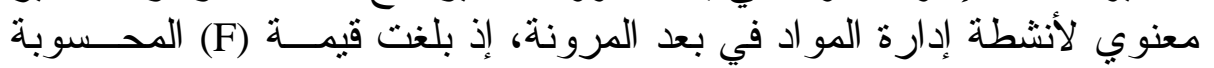

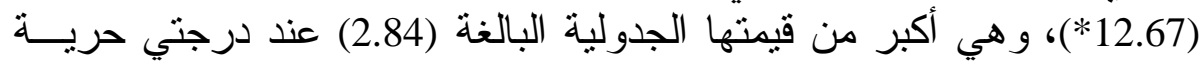

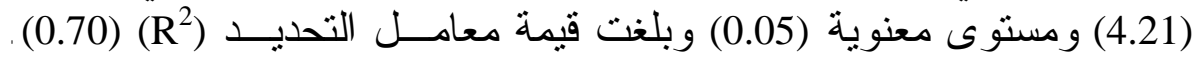
ورن خلال متابعة معاملات (B) و اختيار (t) لها تبين أن أعلى تأثنير لأنشطة

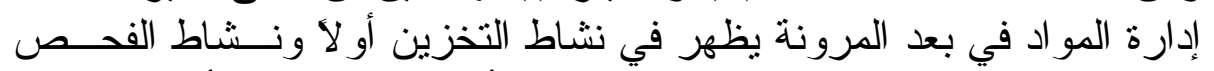

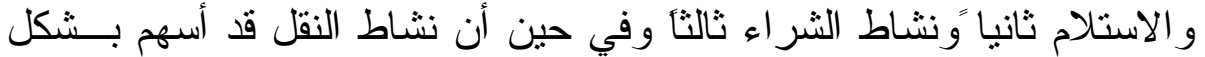

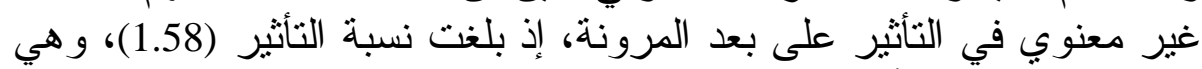

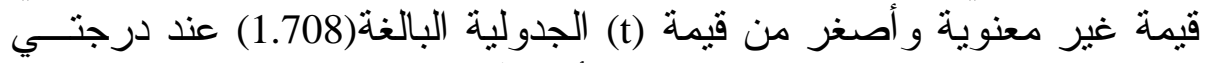

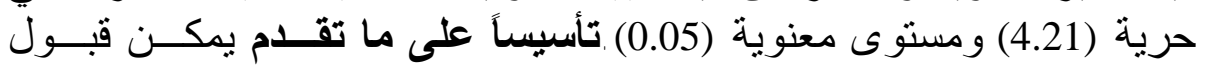

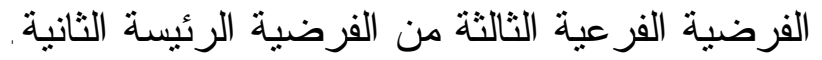

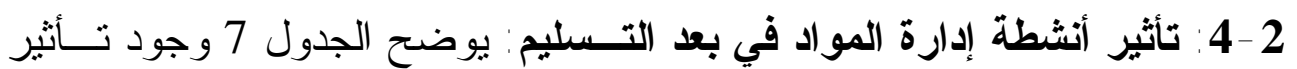

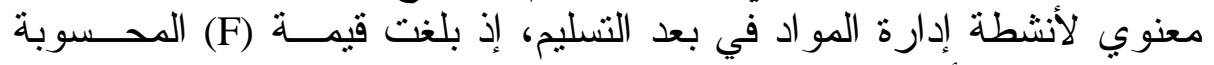

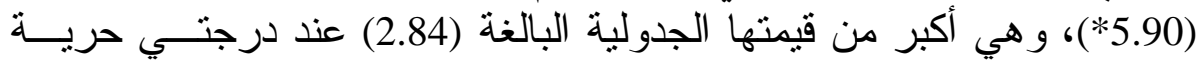

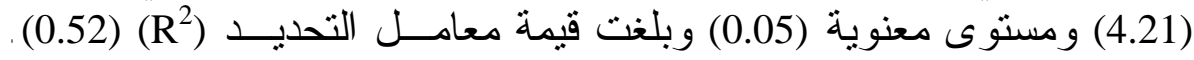
و من خلال متابعة معاملات (B) و اختبار (t) لها تبين أن أن أعلى تأنثير لأنشطة

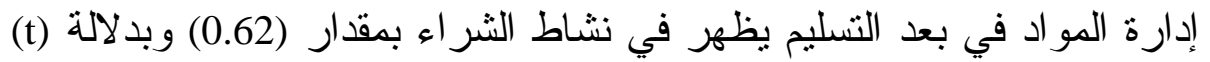

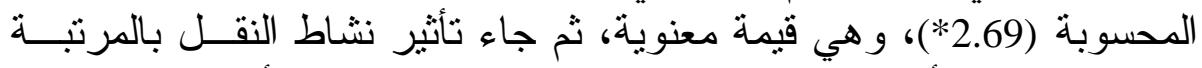

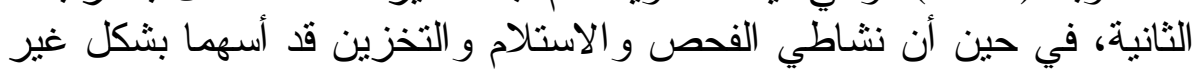

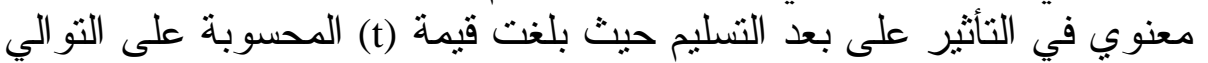

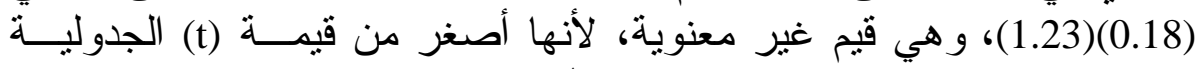

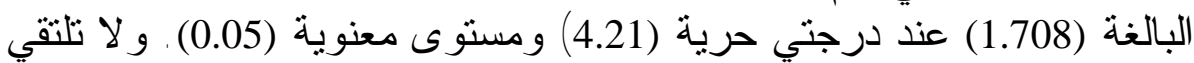

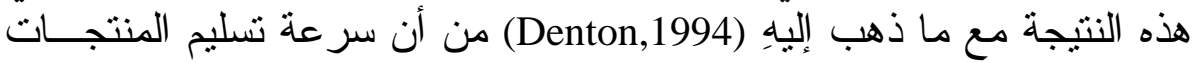

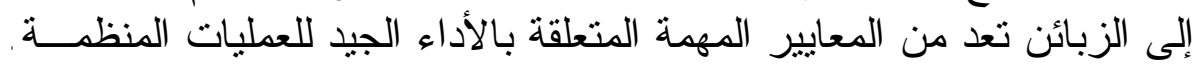

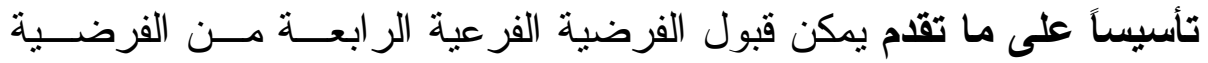
الرئيسة الثانية . تلئية

الاستتناجات و المقترحات أولاً - الاستتناجات

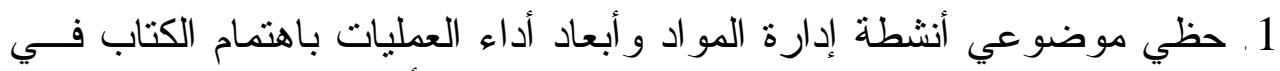

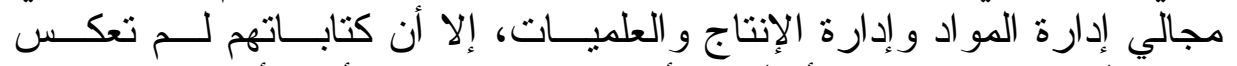

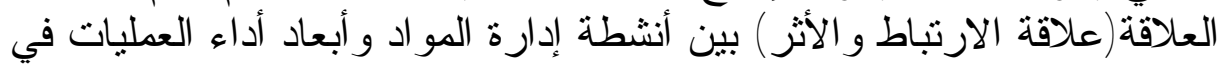

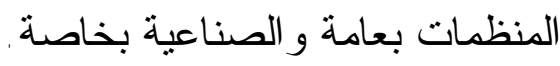
2. يتمتع أغلبية أفر اد عينة الدر اسة بالآتي : 
أ. لديهم خدمة فعلية في المعمل لأكثر من عشر سنوات الات وهي سنوات يكتسـسب

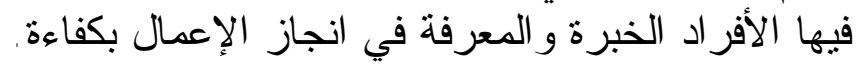

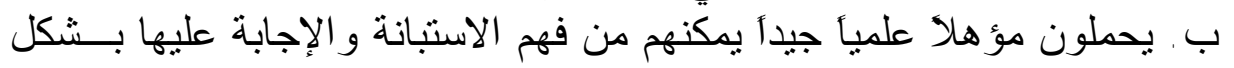

صحيح. 3. أوضحت نتائج تحليل علاقات الارتباط الآتي:

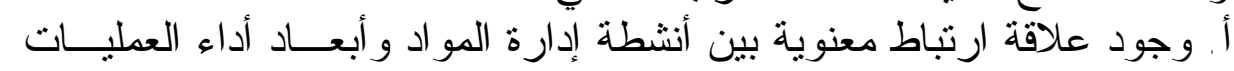

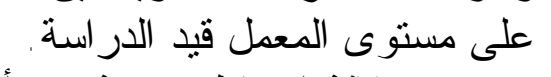
ب. وجود علاقة ارتباط معنوية بين النشطة النشية إدارة المو اد وكل بعد من أبعاد أداء

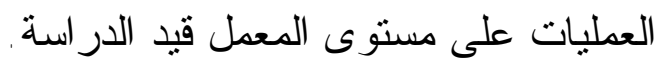
4. كثفت نتائج تحليل الانحدار الآتي:

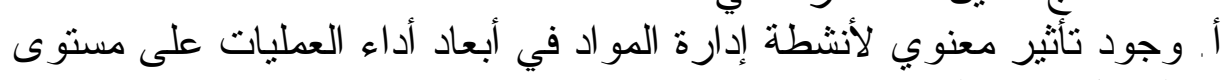

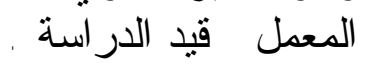
ب. وجود نأثثير معنوي لأنشطة إدارة المو اد في كل بعد من أبعاد أداء العمليات

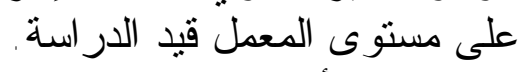

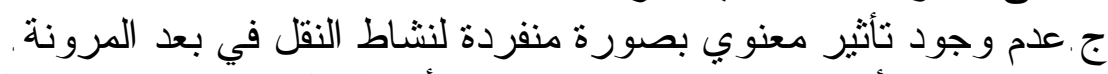
ء.عدم وجود ثأثثير معنوي معني بصورة منفردة لأنشطة الفحص و الاستلام و والتخزين

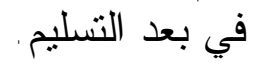

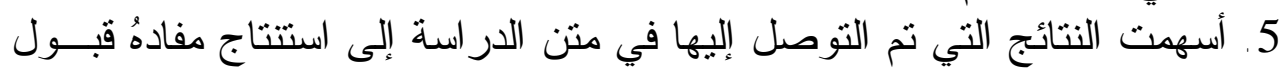

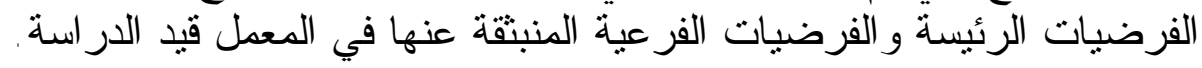

\section{ثانياً - المقترحات}

1. ضرورة قيام إدارة المعمل قيد الدراسة باعتماد مفهوم إدارة المواد بأنشطتهِ

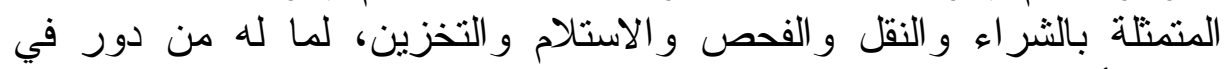

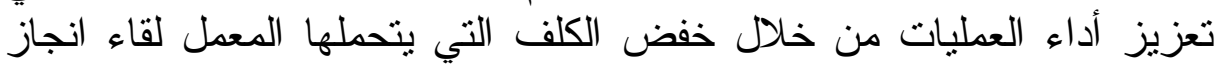

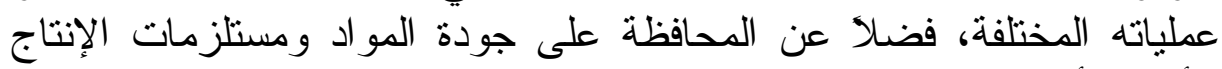
الأخرى أثناء نقلها وتخزينها و استخدامها بهدف تقديم منتجات ذات ذات جودة مميزة الإن تلبي منطلبات الزبائن.

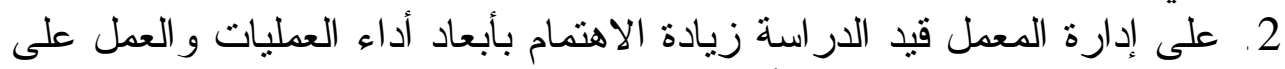

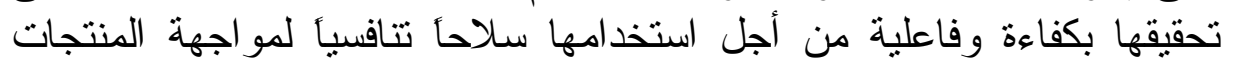

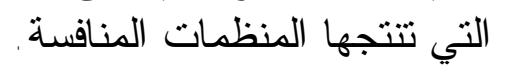

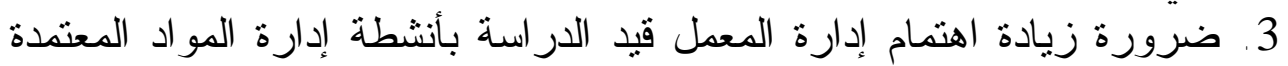

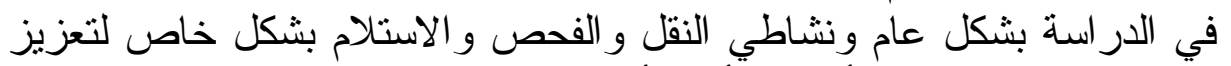
دور ها في تحقيق نتائج أفضل لَأبعاد أداء العمليات. 
الدكتور الطويل والكيكي [298]

4. التأكيد على إدارة المعمل بضرورة ضبط ومعايرة أجهزة و أدو ات فحص المو اد اد الدمان

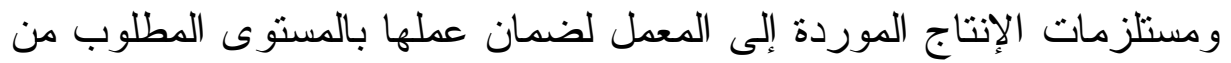

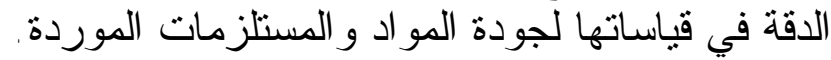

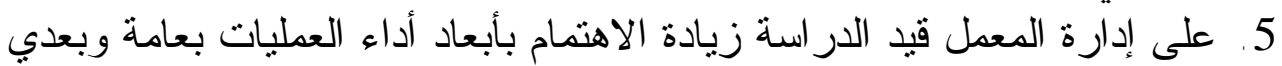

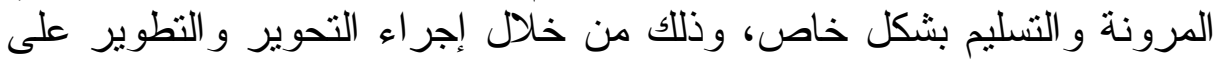

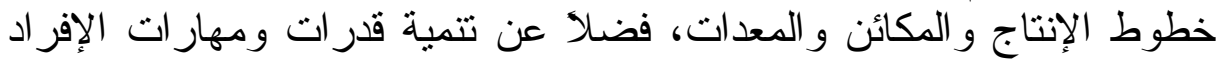

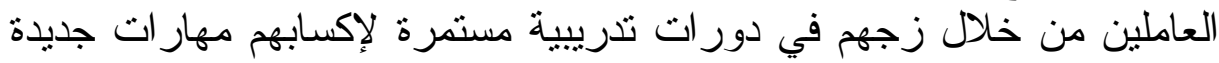

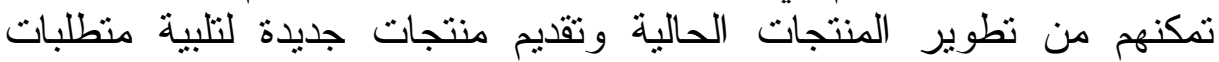

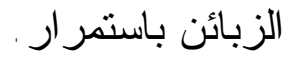

6. التأكيد على إدارة المعمل بالاهنمام بار بالعلاقة بين أنشطة إدارة المو اد و أبعاد أداء

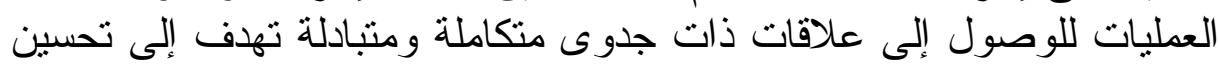
أبعاد أداء العمليات ومن ثم تحسين أداء ألعاء المعمل .

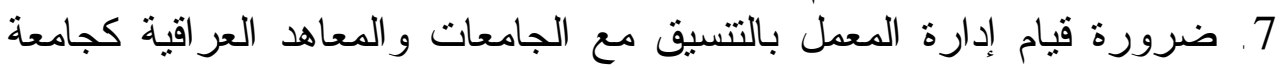

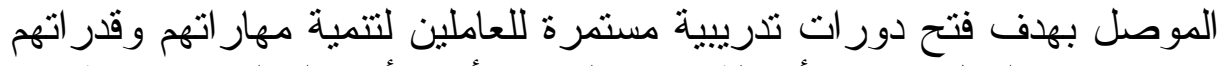

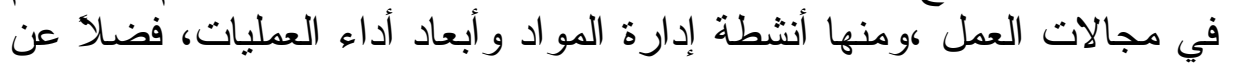

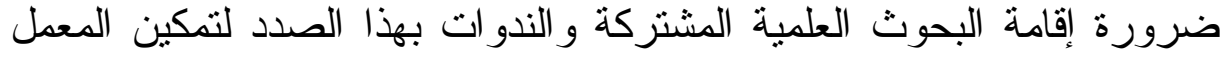
من البقاء و الاستمر ار و النمو في دنيا لأحة الأعمال .

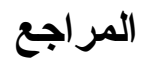 \\ أولاً - المراجع باللفة العربية}

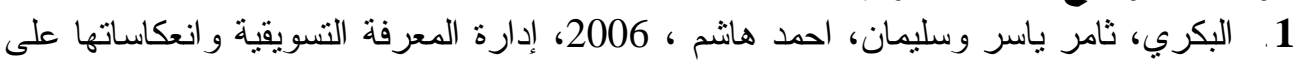

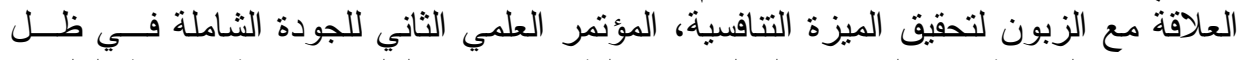

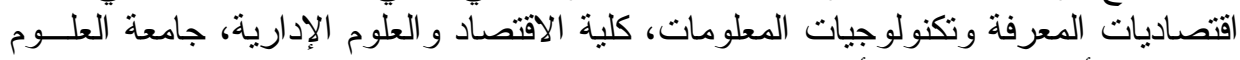

التطبيقية الأردنية، عمان، الأردن.

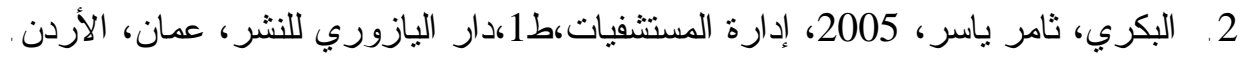

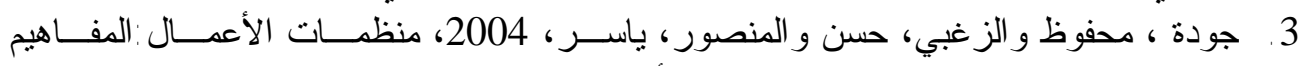

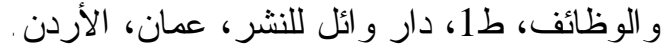

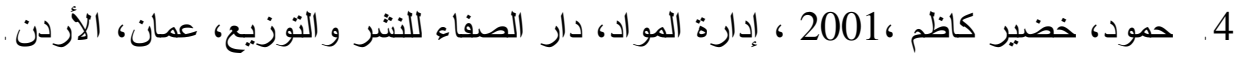

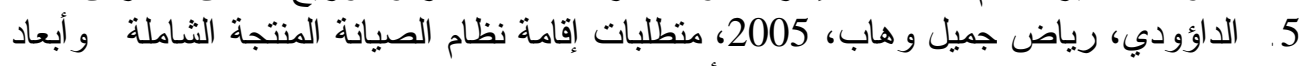

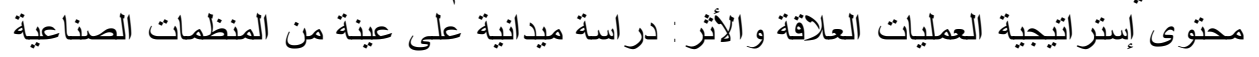

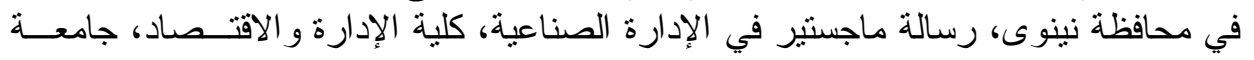

الموصل، غير منشورة. 6. الدباغ، نافع ذنون، 2005، 2005، نظام اللوجستكاك: المفاهيم و الأساسيات، مجلة نتمية الر افدين المجلد

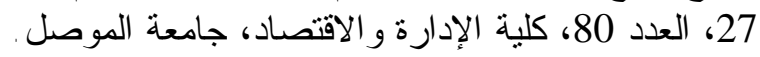

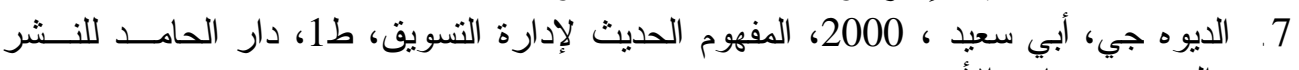
و التوزيع، عمان، الأردن. 
8. الديوه جي، أبي سعيد و الطويل، أكرم احمد وصـادق، درمان سليمان ، 2002، إدارة المـــواد،

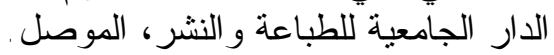

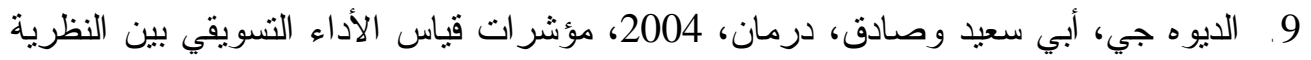

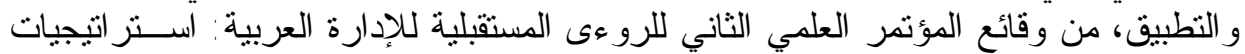

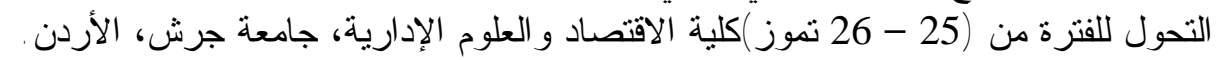

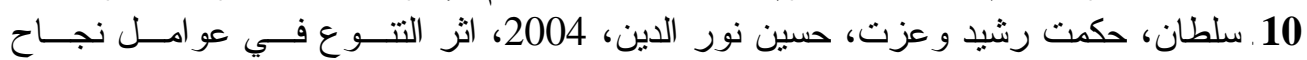

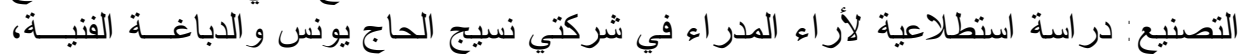

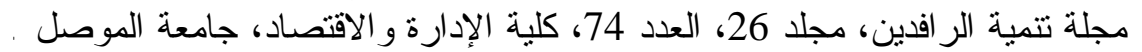

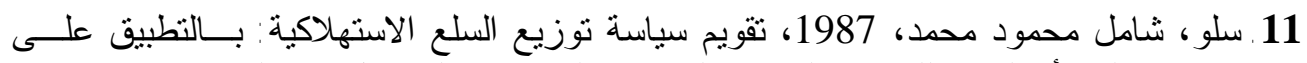

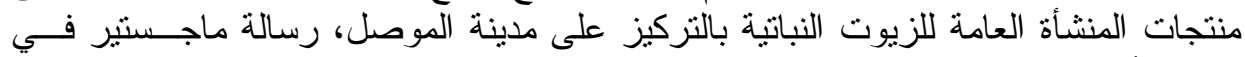

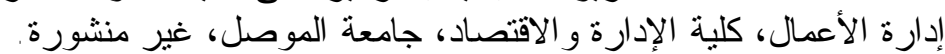

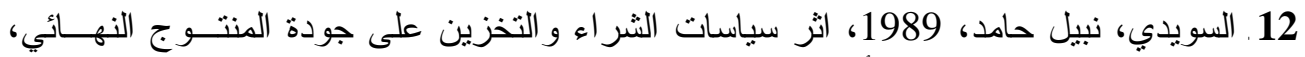

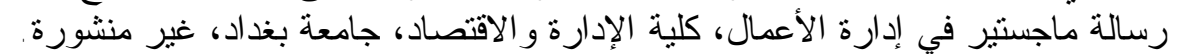

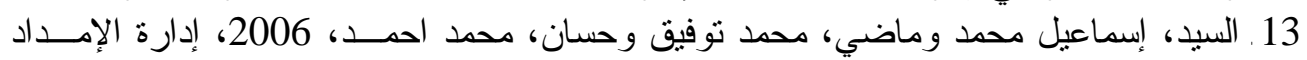

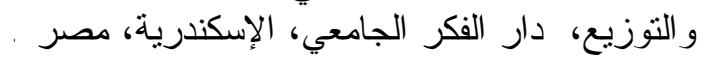

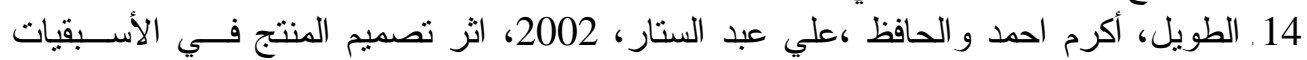

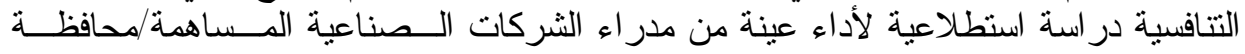

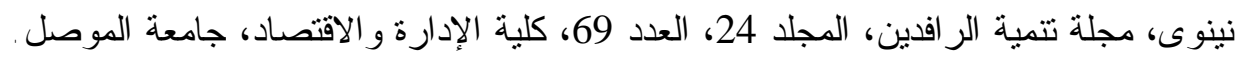

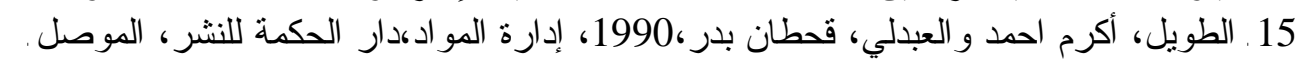

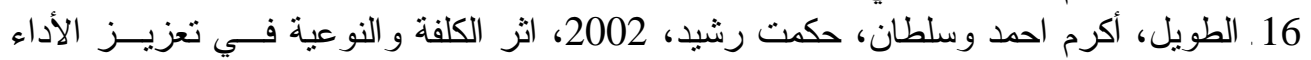

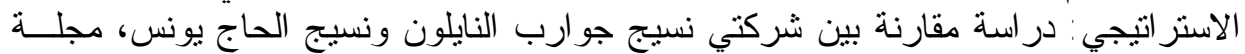

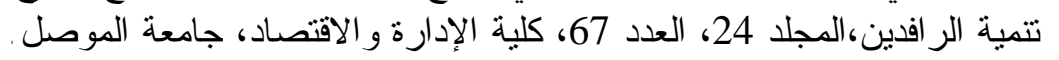

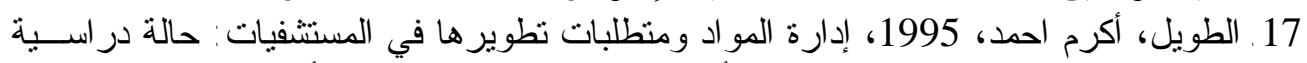

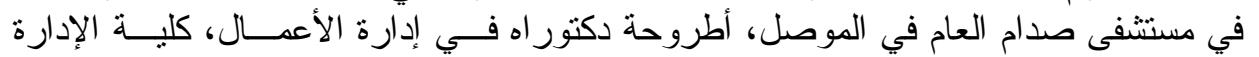

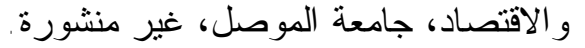

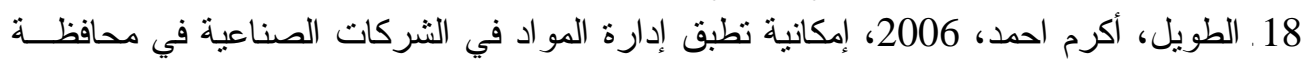

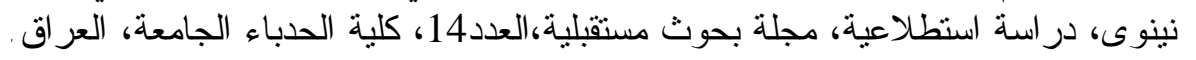

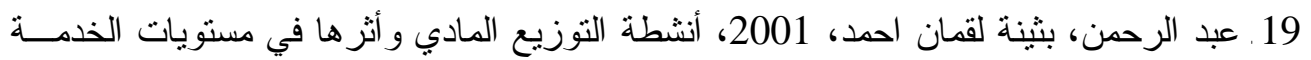

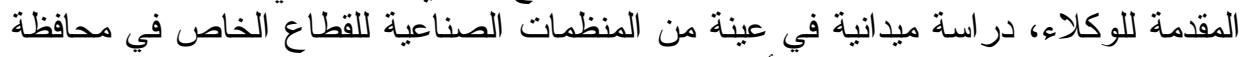

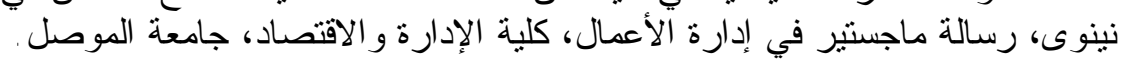

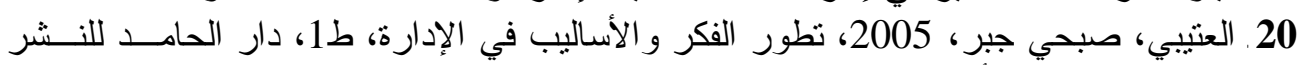

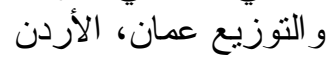

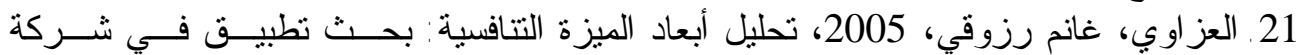

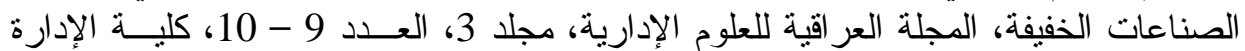
و والاقتصاد، جامعة كربلاء.

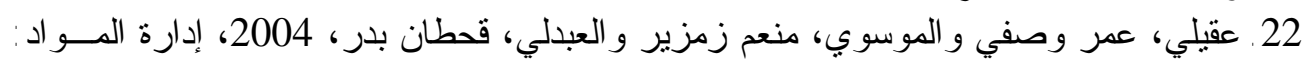

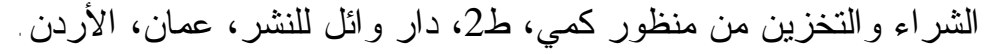

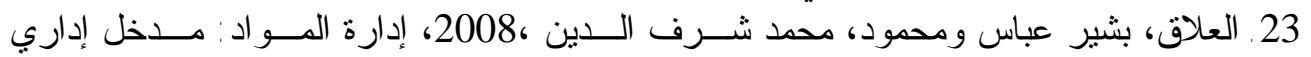
ومحاسبي، دار اليازوري للنشر و التوزيع، عمدان، الأردن . 
الدكتور الطويل والكيكي [300]

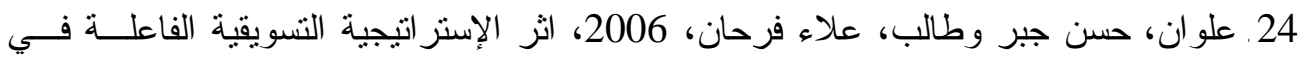

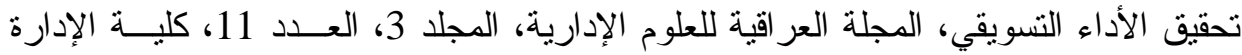

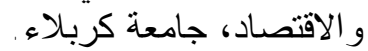

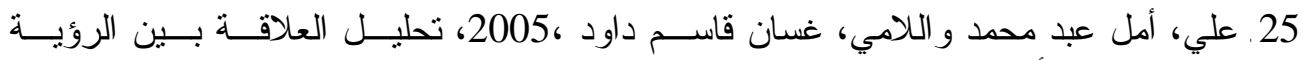

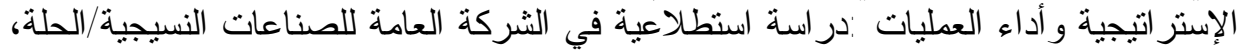

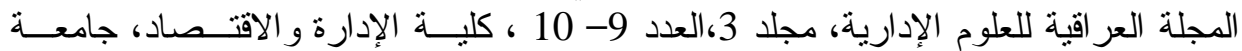
كربلاء.

26. علي، علي حسين ونصر الله، حنا وعريج، عبد وياسين، سعد غالب، 1999، الإدارة الحديثة

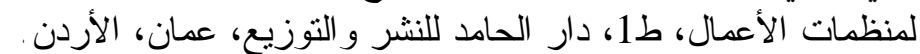

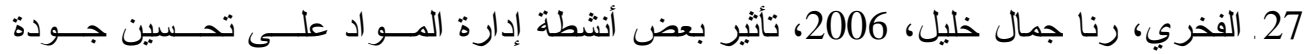

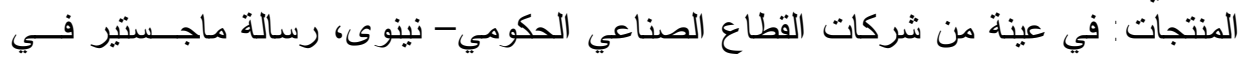

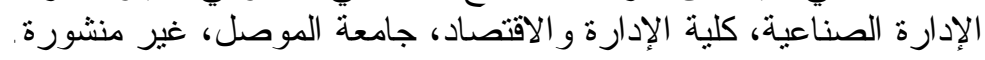

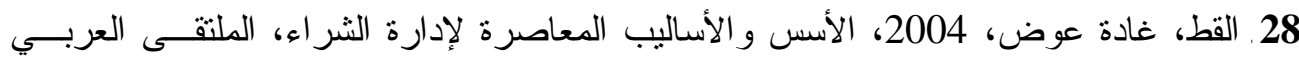

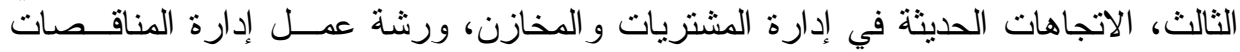

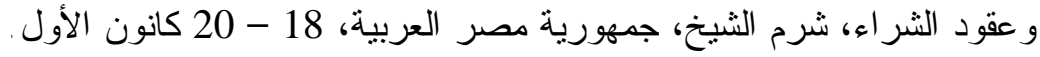

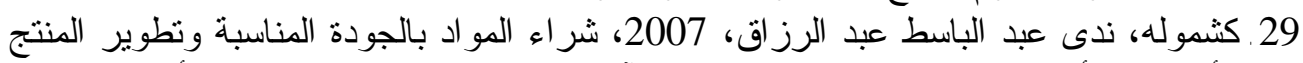

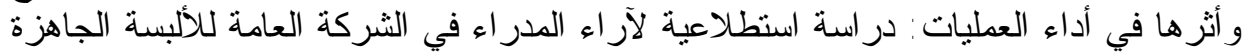

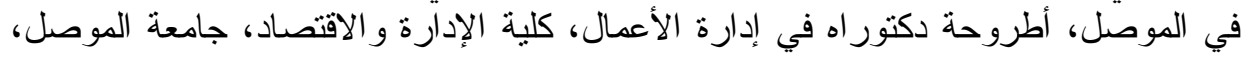

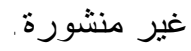

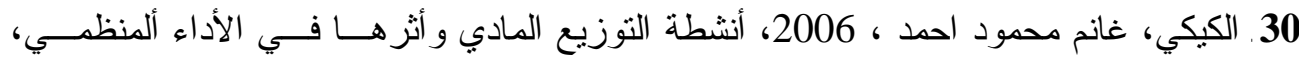

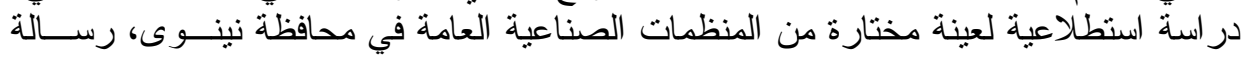

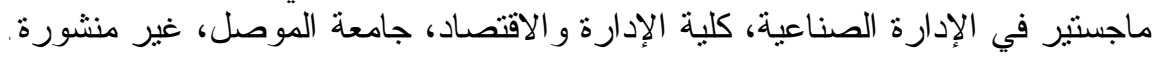

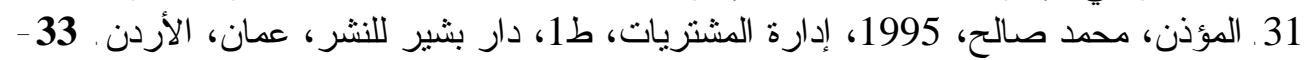

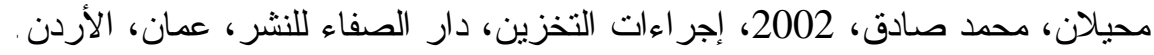

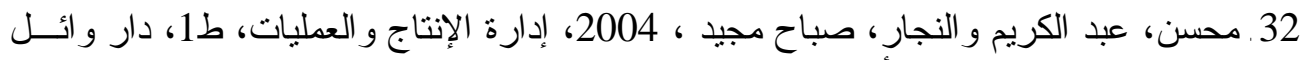
للطباعة و النشر ، عمان، الأردن .

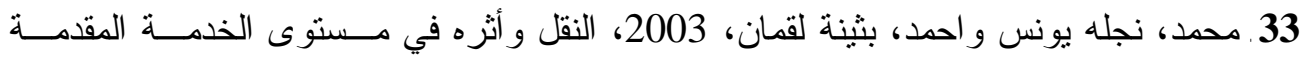

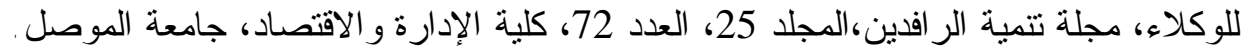

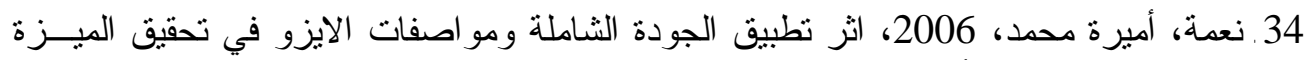

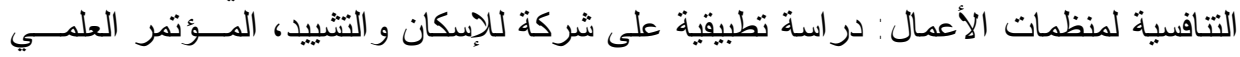

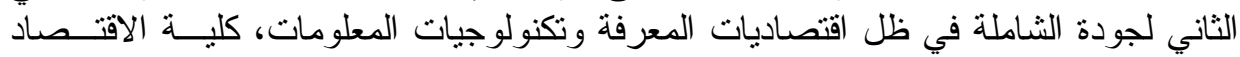
و العلوم الإدارية، جامعة العلوم النطبيقية الأردنية،عمان، الأردن.

\section{ثانياً - المر اجع باللغة الأجنبية}

1. Bovee, Conrtland L \& Houston, Michal J \& Thill, John V,1995, 2d. Ed . Marketing, Mc Graw - Hill, Inc, New York.

2. Chase, Richard B \& Aquilano, Nicholas J, 1995, Production And Operations Management, $7^{\text {th }}$. Ed, The Me Graw - Hill Company, Inc, Boston.

3. Daft, Richard L, 2003, Management, $6^{\text {th }}$ Ed, South, Western,U.S.A.

4. Denton, K. D, 1994, "The Power Of Flexibility" Business Horizon, Vol. 37, No. 4, July - Angust. 
5. Dobler, Donald W \& Burt, David N, 1996, Purchasing And Supply Management, $6^{\text {th }}$ Ed, Mc Graw - Hill Companies, In, New York.

6. Evans, James R \& Collier, David A, 2007, Operations Management, Thomson South Western, U.S.A.

7. Evans, James R, 1997, Production/ Operations Management, $5^{\text {th }}$ Ed, West Publishing Company, New York.

8. Evans, Joel R \& Berman, Barry, 1994, Marketing, $6^{\text {th }}$ Ed, Macmillan Publishing Company, New York.

9. Heizer, Jay \& Render, Barry, 1999, Principles Of Operations Management, $3^{\text {rd }}$ Ed, Prentice - Hall, Inc, New Jersey.

10. Hunger, David J \& Wheelen, Thomas L, 1998, Strategic Management, $6^{\text {th }}$ Ed, Addison Wesley Longmon Inc, New York.

11. Kotler, Philip \& Armstrong, Gary, 1999, Principles Of Marketing, $8^{\text {th }}$ Ed, Prentice Hill. New Jersey.

12. Krajewski, Lee J \& Ritzman, Larry P, 2005, Operations Management, $7^{\text {th }}$ Ed, Pearson Prentice - Hall. New Jersey.

13. Markland, Robert E \& Vickery, Shawnee K \& Daviss, Robert A, 1995, Operations Management, West Publishing Company, New York.

14. Mercr, David, 1992, Marketing, U.K. Blak Well Publisher, London.

15. Noori, Hamid \& Radford, Russell, 1995, Production And Operations Management, Mc Garw - Hill, Inc, N. Y.

16. Pride, William M \& Ferrell, O. C., 1997, Marketing, $10^{\text {th }}$ Ed, Hough Ton Mifflin Company, Boston.

17. Russell, Roberts \& Taylor, Bernard W, 2000, Operations Management, 3th Ed. Prentice - Hall, Inc, New York.

18. Slack, Nigel \& Chambers, Stuart \& Johnston, Robent, 2004, Operations Management, $4^{\text {th }}$ Ed, Prentice - Hall, New York.

19. Solomon, Michael R \& Stuart, Elnora W, 1997, Marketing: Real People, Real Choices, Prinice - Hall, Inc, New Jersey.

20. Waters, Donald, 1996, Operation Management, 1th Ed, Addison - Wesley Publishing Company, Jnc, England.

21. Zenz, Gary J, 1994, Purchasing And The Management Of Material, $6^{\text {th }}$ Ed, John Wiley Of Sons, Inc, New York. 